University of Nebraska - Lincoln

DigitalCommons@University of Nebraska - Lincoln

Papers from the University Studies series (The University of Nebraska)

6-1974

\title{
The Emergence of an Acoustical Art Form: An Analysis of the German Experimental Horspiel of the 1960s
}

Mark Ensign Cory

University of Nebraska - Lincoln

Follow this and additional works at: https://digitalcommons.unl.edu/univstudiespapers

Part of the Arts and Humanities Commons

Cory, Mark Ensign, "The Emergence of an Acoustical Art Form: An Analysis of the German Experimental Horspiel of the 1960s" (1974). Papers from the University Studies series (The University of Nebraska). 47. https://digitalcommons.unl.edu/univstudiespapers/47

This Article is brought to you for free and open access by the University Studies of the University of Nebraska at DigitalCommons@University of Nebraska - Lincoln. It has been accepted for inclusion in Papers from the University Studies series (The University of Nebraska) by an authorized administrator of DigitalCommons@University of Nebraska - Lincoln. 


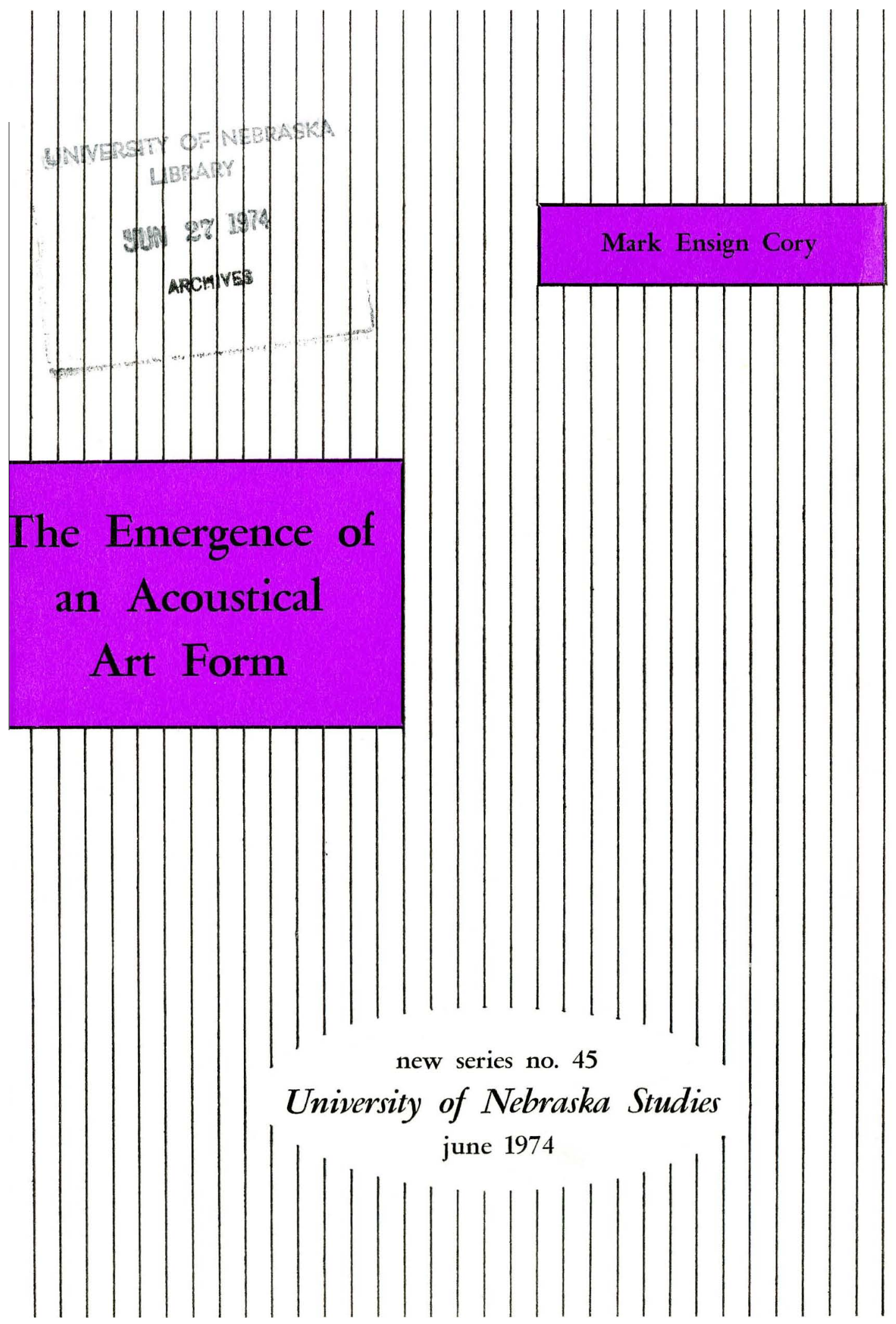




\section{THE EMERGENCE OF AN ACOUSTICAL ART FORM}




\section{The University of Nebraska}

The Board of Regents

Mrs. J. G. Elliott

KERMIT HANSEN

James H. MOYLAN

Robert J. Prokop, M.D., Ph.D.

RoBert L. RAun

EDWARD ScHWARTZKOPF

KERMIT WAGNER
ROBERT R. KOEFOOT, M.D.

chairman

\section{The President}

D. B. VARNER

The Chancellor, University of Nebraska-Lincoln

James H. Zumberge

Committee on Scbolarly Publications

Warren W. Caldwell

Virginia L. FAULKNER

NED S. HEDGES

C. Bertrand Schultz

Gerald E. Thompson
FREDERICK M. LINK, chairman 


\title{
Mark Ensign Cory
}

\section{The Emergence of an Acoustical Art Form}

\author{
An Analysis of the German \\ Experimental Horspiel of the 1960s
}

university of nebraska studies : new series no. 45

publisbed by the university

at lincoln : june 1974 
Copyright (C) 1974 by the Board of Regents of the University of Nebraska Library of Congress Catalog Card Number 74-77088

ISSN 0077-6386

Manufactured in the United States of America 


\section{Contents}

Preface

I. Introduction

II. Preliminary Considerations

III. Nonverbal Elements

1. Sound Effects

2. Music

3. Dimension

4. Silence

IV. Verbal Elements

V. Conclusion and Outlook Bibliography vii

l

11

23

23

38

45

55

68

100

109 


\section{Preface}

$T_{\text {his study GRew out of a fascination with the idea of an acoustical }}$ literature, a body of creative material responsive to the unique possibilities of radio or tape and distinct from creative expression in film, television, and print. Traditional criticism has long held that radio drama constitutes such a body of acoustical literature. The adequacy of this theory was challenged, however, by the emergence in the 1960s of experimental poetic works written for radio which violated many of the canons of classic radio drama and yet seemed somehow more acoustical, more intimately involved with the medium of radio than their predecessors. This experimentation has been particularly active in Germany, where its product has become known generally as "das Neue Hörspiel." In documenting and exploring the development of this new corpus of literary activity, this study seeks to correct certain deficiencies of traditional radio drama theory, while suggesting a critical approach more compatible with an acoustical art form.

Of the many parties whose assistance contributed to this study, the Hörspiel Department of the Bavarian Radio (Bayerischer Rundfunk) deserves first mention. To Hansjörg Schmitthenner of that department I owe special thanks for advice and criticism, and for his enthusiastic and knowledgeable introduction to the experimental Hörspiel. Very helpful also have been the interest and assistance of Klaus Schöning of the Hörspiel Department of the West German Radio (Westdeutscher Rundfunk). The many instances of specific indebtedness to his writings are documented in my text, but in general his help in making available manuscripts of numerous radio essays and other material of difficult access has been inestimable. I am grateful to the Germanistic Society of America and to the Fulbright Commission for supporting the year of preliminary study spent in Germany. And for its generous support during the writing of the dissertation on which this study is based, I thank the Woodrow Wilson Foundation. To Paul Pörtner and Ferdinand Kriwet 
viii / Preface

goes deep appreciation for the use of unpublished materials and tapes of their works. For the benefit of her special competence in concrete poetry go thanks to Mary Ellen Solt. And finally, for their guidance and close attention to the manuscript during the preparation of the original dissertation, I thank Professors Richard C. Burke, Burghard Dedner, Albrecht Holschuh, Melvin Plotinsky, and Frank G. Ryder of Indiana University. 


\section{Introduction}

The era of the traditional Hörspiel has passed. Although they have an important and welcome place in the repertory of every German broadcaster, the radio plays of Günter Eich, the lyrical fantasies of Ingeborg Bachmann, the suspenseful stories of Friedrich Dürrenmatt, the interior monologues of Heinrich Böll, Dieter Wellershoff, and Peter Hirche no longer influence the creative energies at work in the genre as they did throughout the $1950 \mathrm{~s}$. They are in a sense museum pieces to which the term "classic" has already been widely applied. What has followed the mature classic period possesses the vigor of youth and the freshness of innovation. Called simply "das Neue Hörspiel," the successor to the traditional German radio play has pulled the genre out of near stagnation by offering through the radio an aesthetic experience different from that available to readers of literature, viewers of film and television, or friends of the concert hall and theater. After more than a decade of active experimentation, there are now signs that a point of transition has been reached in the development of these new forms, and that consequently it may be possible to speak collectively of the first generation of experimental Hörspiele without doing excessive violence to the variety of forces at work. Before still newer forces complicate the task, the opportunity should be taken for a critical look at some of the experimental works themselves, including an examination of their generic characteristics and their principal features of form and content. It is my belief that in this process a fresh perspective will be won for a reevaluation of the classic Hörspiel and its important theoretical corpus.

The starting point for any attempt to understand the respective natures of the traditional and experimental Hörspiel must be the postulate on which the theory of the entire genre has been based. This postulate, as formulated in the wave of generally sound theoretical and practical criticism that emerged in the years 1961 to 
1964, expressed the belief that there was a necessary relationship between the acoustical medium of radio and the poetic expression of the Hörspiel. It became a cliché, echoed uncritically by all the major theorists, that the Hörspiel was an exclusively acoustical art form. Armin P. Frank observed "Rundfunksendungen im weitesten Sinn, also auch Hörspiele, sind ausschliesslich akustische Gestalten." E. Kurt Fischer spoke of the Hörspiel as "eine rein akustische Darbietungsform," and Heinz Schwitzke of the "akustische Wirklichkeit des Hörspiels." 1 Not surprisingly, the handbooks of literature seized upon this "basic feature" as the starting point for their discussion of the genre. Gero von Wilpert's Sachwörterbuch der Literatur (4th ed., 1964 and 5th ed., 1969) begins its characterization of the Hörspiel accordingly:

HÖRSPIEL als neue dramatische Lit.gattung seit der Erfindung des Rundfunks (erstes H. 6.10.1923 Glasgow) ist gekennzeichnet durch Wegfall alles Optischen (Szene, Mimik, Milieu, Schauplatz, Kulisse, oft durch sog. Geräuschkulisse ersetzt) zugunsten des rein Akustischen ....

The present study will argue that this premise, so reasonable on its face, was in fact premature; that it better characterizes the new variety of Hörspiel which, ironically, emerged only after the definition of the classic Hörspiel as a "rein akustische" art form. The consequence of this premature characterization has been a corresponding neglect of the role of the visual dimension in the classic Hörspiel and an almost total disregard of the phenomenon of the printed text. The perspective gained by an evaluation of the newer and increasingly acoustical form of the Hörspiel will demonstrate that the typical work of the classic era operates aesthetically in visual, not acoustical, terms, and that much of the excellent theory published on the "exclusively acoustical" Hörspiel applies with equal validity to the Hörspiel as printed text.

To develop the perspective afforded by the experimental $H \ddot{r}$ spiel it will be necessary to borrow from the principles and terminology of modern aesthetics, especially those aspects which involve communication, information, and game theory, and the theory of signs. ${ }^{2}$ This approach recommends itself for two reasons. First, the insights offered by these theories are helpful in testing theses like the one on which this study is based. For example, the fundamental semiotic distinction between signal and sign can bring us a long way in an exploration of the relationship between poetic 
expression and its medium. The very quality of the Hörspiel as a "Zwischengebilde sui generis zwischen reinem Phantasieraum wie in gelesener Dichtung, und einem Wirklichkeitsraum für den Dialog wie im Bühnenspiel" 3 leads easily to confusion when its acoustical quality is discussed in traditional literary terms. On the one hand, the classic theorists were of course correct in identifying the medium as an exclusively acoustical one-on the other hand, Friedrich Knilli, in his 1959 dissertation "Das Hörspiel in der Vorstellungswelt des Hörers" (Graz), documented widespread visual activity in the imagination of the listener. This observation led to his early and solitary struggle for a new possibility of Hörspiel-a "totales Schallspiel" which would function aesthetically totally within the acoustical dimension. Unfortunately the analytical tools used by the parties in this dispute were insufficient to open real and meaningful debate. The result was a summary rejection of Knilli's arguments by the majority of theorists (especially Heinz Schwitzke) and an uncompromising rejection by Knilli of the corpus of extant Hörspiele as "romantisches Lesedrama."4

Although the theory which has developed around the experimental Hörspiel makes use of Knilli's observations, the classic theory remains even now reluctant to sacrifice any portion of its claim to acoustical primacy. Actually, the competing arguments become compatible with the introduction of the semiotic distinction between signal and sign:

Die Entstehung dessen, was wir in der künstlerischen Produktion ein "Bild" oder einen "Text," "Poesie" oder "Prosa" mennen, ist in jedem Falle an die Möglichkeit gebunden, physikalische Ordnungen materialer "Signale" als ästhetische Ordnungen immaterialer "Zeichen" einzuführen."

In figure 1 (adapted from Bense, Semiotik, p. 47), this distinction is represented schematically.

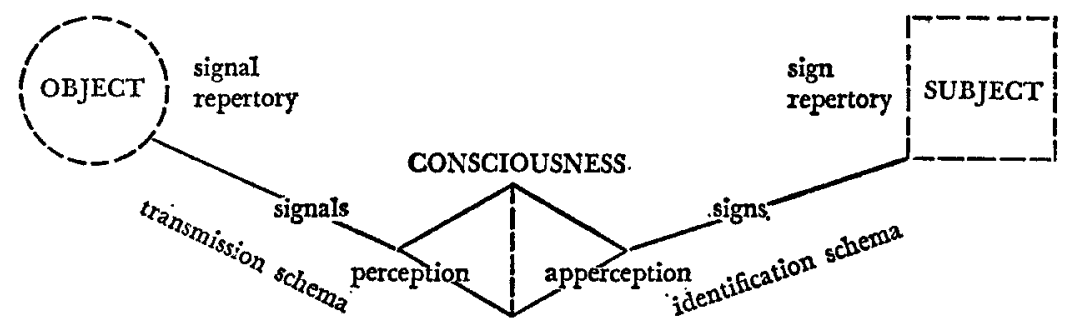


Without trying to dismiss I. A. Richards's caution about the diffculty of representing diagrammatically the perceptual activity of the imagination, ${ }^{6}$ I submit that this schema can be helpful. It demonstrates that a broadcast text is exclusively acoustical throughout its transmission-the signals (sound stimuli) impinging upon the listener's consciousness are wholly acoustical. The reception of these signals constitutes perception, in the narrower sense of an "immediate discriminatory response of the organism to energyactivating sense organs." 7 But apperception, or interpretation, of these signals occurs only as the signals are identified in terms of signs, which then are not necessarily acoustical. ${ }^{8}$ The analytical impasse reached in the Knilli-Schwitzke debate was based upon a confusion of these two aspects of the communication process. The Hörspiel (as broadcast) is exclusively acoustical in terms of perception, but, depending upon the nature of the signs involved, capable of functioning apperceptively in a totally different mode.

An empirical test of the aptness of this distinction and consequently of the advantages of drawing upon these theories for analysis can be made by comparing a portion of the text of a Hörspiel with an acoustical realization of the same excerpt. The following scene is from Wolfgang Borchert's Draussen vor der Tür (1947): ${ }^{9}$

Der Traum

In der Elbe, Eintöniges Klatschen kleiner Wellen.

Die Elbe. Beckmann

BeckmanN: Wo bin ich? Mein Gott, wo bin ich denn hier?

ELBE: Bei mir.

BeckmanN: Bei dir? Und-wer bist du?

ELbE: Wer soll ich denn sein, du Küken, wenn du in St. Pauli von den Landungsbrücken ins Wasser springst?

BeckManN: Die Elbe?

Elbe: Ja, die. Die Elbe.

Brckmann: staunt Du bist die Elbe!

ELBE: Persönlich. Ah, da reisst du deine Kinderaugen auf, wie? Du hast wohl gedacht, ich wäre ein romantisches junges Mädchen mit blassgrünem Teint? Typ Ophelia mit Wasserrosen im aufgelösten Haar? Du hast am Ende gedacht, du könntest in meinen süssduftenden Lilienarmen die Ewigkeit verbringen. Nee, mein Sohn, das war ein Irrtum von dir. Ich bin weder romantisch noch süssduftend. Ein anständiger Fluss stinkt. Jawohl. Nach öl und Fisch. Was willst du hier?

It is largely because of sections like the above that Borchert's work is considered an early example of a mature, classic Hörspiel. ${ }^{10}$ The tangible incorporation through actors on the stage of a higher, 
poetic reality (such as the Elbe) can severely limit the imaginative forms this reality is supposed to suggest. ${ }^{11}$ In a Hörspiel this limitation is overcome by the absence of a visual stimulus. Thus the effectiveness of the piece, the traditional view would have it, is enhanced by the "exclusively acoustical" nature of its realization. But is it? Traditional Hörspiel theory implies that a careful comparison of the text with the recorded performance should reveal significant differences in the aesthetic experiences. According to our analysis, the listener perceives acoustical signals which are apperceived as words-and as sounds. The reader, on the other hand, perceives visual signals which are apperceived as wordsand as sounds. The crucial question is whether the two forms of transmission of the text produce different poetic experiences or orders of images. The listening experience may be more or less pleasant than the reading (depending upon the performance), but the imagination of the reader is clearly excited along the same lines as the listener's, and with approximately the same result. The sound effects that precede the dialogue are apperceived without difficulty as acoustical signs (the exact quality of which depends upon the individual reader's "repertory"-his personal inventory of acoustical impressions of lapping wavelets) from the perceived signals "eintöniges Klatschen kleiner Wellen." And the difficulties conceivably encountered by an audience to a stage production of the work (the amorphous non-image of a speaking river) are overcome as easily by the reader as by the listener. Because this portion at least of Draussen vor der Tür does not necessarily involve acoustical signals for its aesthetic result, it is as effective read as heard. We will encounter works in the course of this investigation for which the signals perceived through reading do not result in the same experience as those perceived acoustically. This is one of the fundamental differences between the old and new Hörspiel, and a large part of the argument in the following chapters will be devoted to its full elucidation. Communication theory, information theory, and the theory of signs, used as in this example to analyze the processes involved in the experience of a Hörspiel, will be invaluable to this argument.

The second reason for drawing upon these theories lies in the fact that many contemporary Hörspiele are written in awareness of them and not infrequently are comprehensible only with reference to their principles. For example, the interpreter armed only with the traditional tools of literary analysis might find it difficult to 
account for material such as the following from Monolog der Terry Jo by Ludwig Harig and Max Bense (1968):

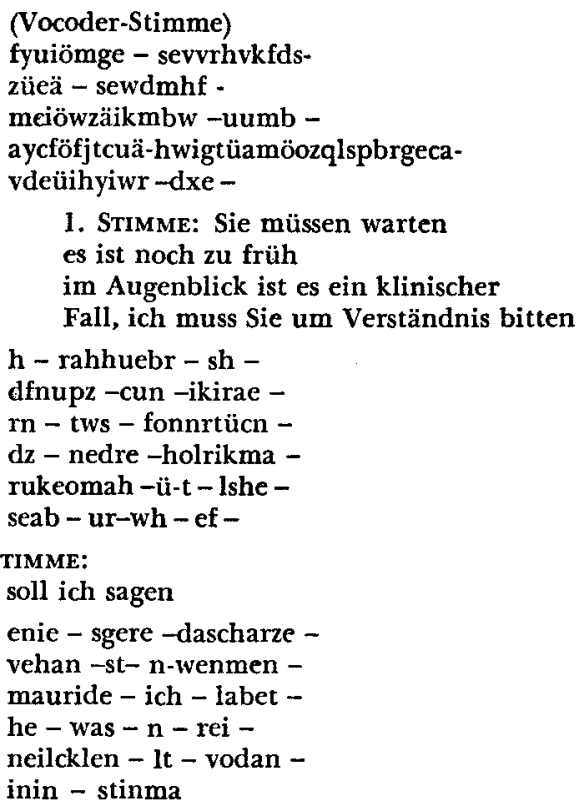

A foreword to the text explains that this unusual piece is structured from the interplay of a monologue of an accident victim (Terry Jo) and the reports of several others connected with the investigation into the accident (Stimmen). At the beginning of the piece (the passage quoted above), Terry Jo is unconscious. Her monologue is built up by several stages, each a closer approximation (achieved through a computer) to "conscious" speech. The effect of the approximation is seen in the third segment of the monologue, in which the first recognizable words appear ("ich," "was"). What the foreword does not mention is that in communication theory this device of approximating language demonstrates the value of context for communication. ${ }^{12}$ In the light of this theory, Terry Jo's monologue begins to take on meaning for us as it builds its linguistic context (i.e., as it increasingly approximates language). The other statements (Stimmen), initially meaningful as distinct elements, begin to lose their individual meanings as the larger context of the events surrounding the accident develops. These statements begin to contradict each other, some attesting to a character's harm- 
lessness, others to his treacherousness. Only the monologue, insulated from hearsay, prejudice, and deception by the speaker's unconsciousness, obeys the mathematical rules of language and is able to convey the truth. Der Monolog der Terry Jo is an innovative and fascinating statement on the disintegrating effect of the social nexus upon language as communication.

Most contemporary Hörspiele draw less explicitly upon these theories than Terry Jo, but many are nevertheless interpretable in their terms. Furthermore, other characteristics basic to this first generation of experiments have as their source these same aesthetic principles. For example, the dramaturgical zeal that elevated the word to a position of supremacy over nonverbal elements in the classic Hörspiel, while paradoxically ignoring the worth of the printed text, is often reversed in the experimental Hörspiel. There this hierarchy of word over sound effect and music is loosened and sometimes inverted. The film scene ("Der Junge wird zum Mann / Filme regen an") from the 1968 Fünf Mann Menschen by Ernst Jandl and Friederike Mayröcker offers an excellent illustration of this new distribution of acoustical elements. Although here the word is still important, sound effects and music have a much larger share in that importance than is the case in the classic Hörspiel. In over eighty seconds of material, only eighteen words are spoken, eight of which constitute the proverb-like introduction to the scene. The remaining ten are equally divided between the film gangsters and the audience of young men. The prominence of the latter five utterances is further diminished by the fact that they are essentially composed of only two dominant sounds (variously combined in word play among "koks," "o.k.," and "K.O."). The classic formula whereby sound effects are lightly interspersed throughout a piece to accentuate and illustrate the development of the word-dominated action is reversed. In this scene the action is carried by sound effects and music, and illustrated through sparsely interspersed words. ${ }^{13}$ The semantic dimension has not been neglected, but it is clearly only one portion of a total aesthetic message in which rhythm and the playful combination of verbal and nonverbal elements have powerful roles. Communication and game theories will help explain why the word dominated a genre where the meaning of the message was of prime importance, and why in the new Hörspiel, with its sometimes radically different emphasis, the hierarchy may be reversed. 
8 / The Emergence of an Acoustical Art Form

The balance of this investigation will proceed to define and illustrate element by element these and other differences between the old and the new in the Hörspiel, and to look at the consequences they produce. The application of certain principles of information aesthetics to such an analysis will become clearer as the newer pieces are introduced. And I trust the reader will come to value the frequent references to actual recorded performances of many of the Hörspiele discussed as the most appropriate method of testing statements about the acoustical nature of an art form. 


\section{NOTES}

1. Armin P. Frank, Das Hörspiel: Vergleichende Beschreibung und Analyse einer neuen Kunst form (Heidelberg, 1963), p. 78; E. Kurt Fischer, Das Hörspiel: Form und Funktion (Stuttgart, 1964), p. 22; Heinz Schwitzke, "Bericht über eine junge Kunstform," in Sprich, damit ich dich sehe, ed. Heinz Schwitzke (Munich, $1960)$, p. 16. Subsequent reference to these works will be given in the text.

2. I stress that I will be borrowing from these theories, not attempting a direct and systematic analysis according to their principles. For examples of such systematic analysis see the studies by Peter Schraud, "Theater als Information," Diss. Vienna 1964, and Waltraud Reichert, "Informationsästhetische Unterschuchungen an Dramen," Diss. Stuttgart 1965.

3. Herman Pongs, quoted in Horst-Walter Krautkrämer, "Das deutsche Hörspiel 1945-1961," Diss. Heidelberg 1962, p. 204. Hereafter, Krautkrämer.

4. Friedrich Knilli, Deutsche Lautsprecher: Versuche zu einer Semiotik des Radios (Stuttgart, 1970), p. 59. Knilli has attempted in this volume to make again some of the points included in his original dissertation (1959) and subsequent book on the Hörspiel (1961). Now, however, these points are fortified with new chapters on communication and information theory. Hereafter, Lautsprecher.

5. Max Bense, Semiotik (Baden-Baden, 1967), p. 22. Subsequent reference given in text.

6. Richards makes this point while nevertheless suggesting a diagram of his own. I. A. Richards, Principles of Literary Criticism, 4th ed. (New York, 1965), pp. 116, 131. Hereafter, Principles.

7. Samuel Howard Bartley, Principles of Perception, 2nd ed. (New York, 1969), p. 11. Hereafter, Bartley.

8. "Zeichen können Gexäusche, Laute, Töne, Stimmen und Wörter sein, vorausgesetzt, dass sie zur Bezeichnung von Gegenständen und Sachverhalten benutzt werden." Knilli, Lautsprecher, p. 8.

9. For editions of Hörspiele cited in this study, consult Appendix. Page references for quoted material will hereafter appear in the text, with abbreviated reference to the edition used, e.g., in this case 16 dt. Hörspiele, p. 139.

10. For example, the discussion in Krautkrämer, p. 33: "Es ist kein Zufall, dass Draussen vor der $T$ ür seine Urafführung im Rundfunk erlebte, denn bis in die Feinheiten des dramaturgischen Baues hinein kann man verfolgen, dass es mit den und für die Mittel des Rundfunks geschrieben wurde. Die spätere Umarbeitung für Bühnenaufführungen zeigen deswegen immer einen Rest Unzulänglichkeit bzw. bleiben sogar auf 'funkische' Mittel angewiesen, wie in jener Ohnmachtsszene, in der die Elbe Stimme gewinnt und mit dem Ertrinkenden spricht."

11. See, for example, Eugene Ionesco's lament over the distraction of the imagination in the theater by the physical presence of actors on the stage. Quoted in Heinz Schwitzke, Das Hörspiel: Dramaturgie und Geschichte (Cologne, 1963), p. 242. Hereafter, Das Hörspiel.

12. "When separate units are selected in a contextual vacuum (zero- or firstorder approximation), it is impossible to produce anything that looks like the language we daily use. As the amount of context that determines each unit is increased, however, the resulting sequences of words take on a more familiar aspect." George Miller, Language and Communication (New York, 1951), p. 85. For a more detailed description of stochastic processes see Claude E. Shannon and Warren Weaver, The Mathematical Theory of Communication (Urbana, 1964), pp. 11 f. Hereafter, Shannon and Weaver. 


\section{0 / The Emergence of an Acoustical Art Form}

13. A test of the relative importance of verbal and nonverbal elements in this scene can be conducted by listening to the record, mentally editing first one and then the other category. The remarkable thing is how far this can be carried in one direction, and how little in the other. 


\section{Preliminary Considerations}

I RONICALIY, THE PREDILECTION for verbal over nonverbal elements referred to on page 7 arose during a time when technical innovations were continually adding to the stock of special effects available to author and producer alike. More than merely an anomaly in the history of the genre, this rejection of the temptation to use increasingly spectacular sound effects bears significantly on the question of the different acoustical natures of classic and experimental Hörspiele. It is therefore pertinent to sketch the evolution of the balance between verbal and nonverbal elements in general before describing the behavior of each element separately.

In the earliest Hörspiele nonverbal elements had a position of great importance, though not perhaps of dominance. These works were primarily stage dramas reworked for presentation in radio. Since radio was at that time in competition with the visuallyoriented media of theater and film, the absence of visual stimuli was felt to be a handicap that would have to be compensated for by extensive use of sound effects. Some of the pioneers felt that the Hörspiel had to offer spectacular sound effects ("unheimliches Knattern, Rollen und Rauschen") ${ }^{1}$ in order to catch and maintain the listener's attention; others contented themselves with attempting to transfer the physical action of the play and the stage sets from the visual to the acoustic dimension. The result was the evolution of the "Geräuschkulisse," whereby authors and producers sought to replace everything in the theater which engages the eyegesture, costume, scenery-with (predominantly natural) sound effects. The Geräuschkulisse became a standard feature of most early Hörspiele and persists today, although primarily in adaptations of works from other genres and in the popular radio pieces designed mainly for entertainment of the general listening audience (e.g., mystery programs). The American radio audience of the 1940 s and 50s was made familiar with this use of sound effect through much the same sort of programming (e.g., The Shadow, Gang- 


\section{2 / The Emergence of an Acoustical Art Form}

busters, The Green Hornet). Although it represents an economical way to make literature "work" in radio, the concept of the Geräuschkulisse was subjected to increasingly heavy criticism. Many writers saw more potential for a unique creative experience in the Hörspiel and were unwilling to limit it to a mere reworking of material from other genres. Creative radio, it was felt, had to offer something better than an acoustical approximation of theatrical effects. The potential of the new medium could never be tapped as long as the main effort was spent on compensating for a handicap. Somehow the lack of visual stimuli had to be turned into an advantage. The results were substantial, even revolutionary. Action was internalized, realistic physical dimensions suspended, and time telescoped-all in the interest of new artistic, symbolic, and increasingly lyric (as opposed to dramatic) effects. The number of examples grew in which the role of realistic sound effects was reduced to a minimum. Finally, in the mature classic Hörspiel, the once popular Geräuschkulisse disappears almost entirely, to survive only in the field of entertainment radio. Heinz Schwitzke, writing in 1960, indicates how strong the reaction against the Geräuschkulisse had become:

Jeder feinfühlige Hörer weiss, wie z.B. die Anwendung von grobrealem Lärm, von Schritten und klappenden Türen im Hörspiel als scheussliche Stilwidrigkeit wirken kann, weil damit materielle Wirklichkeit den hauchzarten Schleier der Phantasiewirklichkeit schmerzhaft durchstösst und zerreisst. An dieser Stelle wäre von der Dramaturgie des Geräusches und der Musik im Hörspiel ganz allgemein zu sprechen and davon, dass dem bei wohlmeinend Ahnungslosen so beliebten Begrift "Geräuschkulisse" nichts künstlerisch Brauchbares entspricht.

[Schwitzke, Sprich, p. 19]

Until the new respect accorded nonverbal elements in the contemporary experiments permitted their return in force, they were to occupy quantitatively a relatively minor role in the mature classic era. Even so, this role was considered qualitatively significant by the classic theorists, at least within certain restrictions. These restrictions stem from a principle of fundamental importance to the practice and theory of the classic Hörspiel. Like all traditional literature, it sought to convey a particular view of reality to its audience. The classic Hörspiel, we say, has a "message," and we mean that whatever else it may do, it has reference to something outside its own existence as language. This observation is noteworthy from a historical standpoint. Despite earlier challenges to this tradition of message and meaning from Dada and the Sym- 
bolist poets, and many if not most other avant-garde movements, an art form rich in new technical resources adopted in its first successful period the traditional use of language.

The significance of this principle for the restrictions on nonverbal elements is apparent only when we understand more fully the nature of the message communicated by the classic Hörspiel in its "Wille zur Kommunikation." 2 It will be helpful if we draw on a distinction basic to information theory, that between information and meaning. Whereas in everyday speech these words are often synonymous, "information" in this narrower sense is a mathematical expression of the choice exercised in the selection between two signs. The more unlikely the occurrence of a given sign, the greater the information it contains. Obviously, as a message approaches maximum information it becomes less understandable, since it involves increasingly unlikely sequences of signs. Understanding a linguistic message, that is, extracting meaning, depends upon a certain measure of predictability, upon conventions, the most important of which we call the rules of semantics. Thus meaning, resting upon convention and depending upon a certain minimum measure of predictability, is in this sense the opposite of information. Though not mutually exclusive, information and meaning exist in a message in inverse proportion to each other. ${ }^{3}$

To return now to the observation that the classic Hörspiel was fundamentally concerned "sich zu verständigen," it becomes clear that this concern (which we already felt intuitively to involve meaning) involves specifically a message organized on the semantic level. The significance for the evolution of nonverbal elements stems directly from this principle. Since the basic material of semantics is the word, an abundance of nonverbal elements, if they were also non-semantic, could threaten the semantic message of the Hörspiel. Regardless of what excitement or pleasure they might have offered in themselves, the nonverbal elements were simply reduced below the level of distraction. The reason usually given for the turning away from nonverbal elements is that the genre came to feature fewer realistic plays and more works involving a poetic reality or set in interior monologues where sound effects seem out of place. In the present light, that reason is but part of the answer. The fuller answer lies in the frequently voiced criticism that sound effects alone are unsuitable for an unambiguous statement. ${ }^{4}$ As long as the main criterion was to be the ability to convey a semantic message, the nonverbal potential of the Hörspiel would have to be 
severely restricted. Moreover, this restriction was twofold. Nonverbal elements were to be kept to a minimum and they were to contribute directly to the semantic meaning of the work as a whole. ${ }^{5}$ Authors and producers were urged to employ only those sound effects which would function symbolically or participate directly in the plot.

There is a very important implication in these qualitative and quantitative restrictions. To understand it we must take our examination a layer deeper in communication theory and approach the Hörspiel as a system of signs. Any message-not only a printed text, but the message received by the listener to a Hörspiel as well-can be understood as such a system. The founder of semiotic, Charles S. Peirce, divided the general concept of sign into three sub-categories: index, icon, and symbol. ${ }^{6}$

An index functions as a guide in the communication process. It orients us with respect to the message. A typical example in the Hörspiel would be footsteps announcing the arrival or departure of a character.

An icon is characterized by sharing in some way the features of the form or emotion it represents. An example would be a train whistle as an icon of a train, an anxious cry as an icon of pain or anxiety, or a laugh as an icon of pleasure.

A symbol, sometimes called a pure sign, represents the meaning of a form or emotion but does not participate in its characteristics. Beyond its representative function, a symbol need have no connection with the thing represented. An example might be a knock on a door, symbolizing (within a certain context) racial persecution.

In practice these categories are often less clearly defined, as a given sign may discharge more than one function. To better illustrate how these classes of signs behave, let us analyze a scene from the excellent performance of Wolfgang Borchert's Draussen vor der Tür recorded by Cottas Hörspielbühne. This passage between Beckmann, ex-soldier and returnee from Russian imprisonment, and the husband of the girl who has befriended him after his attempted suicide opens with a series of nonverbal elements: the teck-tock of crutches under Beckmann's anxious remarks to the girl, a woman's scream, and the closing of a door. These function initially as indices, orienting the listener to the departure of the girl and the halting approach of someone else, apparently disabled. The passage ends with a simi- 
lar series of indices orienting us to the departure of Beckmann (door) and his subsequent presence outside (wind, running footsteps). Such a pattern of indices is common in dramatically structured works and organizes the message into what we can call a scene.

The index function does not exhaust the purposes of these sounds, however, for each class of sign contains the potential for expansion to other functions. Thus the scream which identifies the departing character (index function) is also an icon, representing her anxiety. The door closing not only confirms the departure, but in this work exercises a symbolic function: Beckmann constantly faces closed doors, symbols of apathy toward the plight of returning soldiers. Since the closing of a door is itself sometimes an act of rejection, this sign can also function iconically. The third index, the teck-tock sound of crutches, not only orients us as footsteps might, but also serves as an icon, representing and sharing in a characteristic of the "giant"-his crippled state. This icon is similarly elevated to a symbolic level, in that "crippled" must be understood in a wider, sociological frame. At the end of this scene the door closing is again index, icon, and symbol, while the wind is an index on one level, orienting us to the opening of the next scene, and an icon sharing in Beckmann's presence outside: Beckmann is the man outside the closed door, "draussen vor der Tür."

So far we have used the theory of signs to analyze the nonverbal elements only. The theory applies of course to the verbal elements as well. Primarily, all words function as symbols; there is no necessary icon-like sharing in the thing represented (an exception is the class of onomatopoetic words, which will be discussed later). Clearly, however, they can also function as indices, e.g., chapter titles, act designations, and indications of parts in the co-text ${ }^{7}$ of a drama, etc. In both verbal and nonverbal elements, one of these functions will usually dominate in any given occurrence of the sign (e.g., the index function of the wind dominates its iconic function because it carries more information). Larger syntactic units can also be analyzed as to their function as signs. For our present purposes, however, we can stop with the observation that words are primarily symbolic signs and function primarily on the semantic level of meaning.

Yet from our identification of the function of the nonverbal elements in the Borchert scene, we saw that some of these also function on the semantic level: that is, sounds can function sym- 
bolically, in which event they carry semantic meaning as do the words of the dialogue. Symbolic sounds and words both belong to that class of sign most intimately responsible for the communication of semantic meaning.

This, then, is the fuller sense of the classic limitation on nonverbal elements. They were tolerated as indices as long as this use was quantitatively small (the Geräuschkulisse engages primarily the index function), and encouraged only as symbols, where they could make the greatest contribution to the semantic meaning.

Seen in this light, the implication of the restriction on nonverbal elements is profound. At issue is nothing less than whether, so far as the contribution of nonverbal elements to the meaning goes, any case can be made for the necessity of actually hearing a classic Hörspiel. Since nonverbal elements were essentially restricted to indices and symbols, could other codes for these same signs take their places? If so, then the presence of acoustical signals is not necessary for communication of the message; the graphic signal, the word or verbal code for the sound involved, is sufficient. If not, then the presence of acoustical signals is indeed necessary and listening to the Hörspiel would in fact be an experience inaccessible to the reader of the printed text.

Let us return to the scene from Borchert's play discussed above and carry our analysis of the sign inventory one step further: if in an actual acoustical realization (recorded performance) both verbal and nonverbal elements can function as either index, icon, or symbol, can the exclusively verbal elements of the printed text function as signs for nonverbal sounds?

Beckmann: . . Da! Ich habe das GefühI, dass hinter deinem Rücken ein Mann steht! Die ganze Zeit schon. Ein grosser Mann. So eine Art Athlet. Ein Riese, weisst du. Aber das kommt nur, weil ich meine Brille nicht habe, denn der Riese hat nur ein Bein. Er kommt immer näher, der Riese, mit einem Bein und zwei Krücken. Hörst du-teck tock. Teck tock. So machen die Krücken. Jetzt steht er hinter dir. Fühlst du sein Luftholen im Nacken? Gib mir die Brille, ich will ihn nicht mehr sehen! Da, jetzt steht er ganz dicht hinter dir.

MAEDCHEN: schreit auf und stürtz davon. Eine Tür kreischt und schlägt zu. Dann hört man ganz laut das 'Teck tock' der Krücken.

BF.CKMANN: flüstert Der Riese!

Der EINBernige: monoton Was tust du hier. Du? In meinem Zeug? Auf meinem Platz? Bei meiner Frau?

Beckmann: wie gelähmt Dein Zeug? Dein Platz? Deine Frau?

DER EINBEINIGE: immer ganz monoton und apathisch Und du, was du hier tust? BeckmanN: stockend, leise Das hab ich gestern nacht auch den Mann gefragt, der bei meiner Frau war. In meinem Hemd war. In meinem Bett. Was tust du 
hier, du? hab ich gefragt. Da hat er die Schultern hoch gehoben und wieder fallen lassen und hat gesagt: Ja, was tu ich hier. Das hat er geantwortet. Da habe ich die Schlafzimmertür wieder zugemacht, nein, erst noch das Licht wieder ausgemacht. Und dann stand ich draussen.

Der EInbeinige: Komm mit deinem Gesicht unter die Lampe. Ganz nah. dumpf Beckmann!

BeckmanN: Ja. Ich. Beckmann. Ich dachte, du würdest mich nicht mehr kennen.

DER EINBEINIGE: leise, aber mit ungeheurem Vorwurf Beckmann . . . Beckmann ... Beckmann!!!

BECKMANN: gefoltert Hör auf, du. Sag den Namen nicht; Ich will diesen Namen nicht mehr haben! Hör auf, du!

DeR EINBEINIGE: leiert Beckmann. Beckmann.

Beckmann: schreit auf Das bin ich nicht? Das will ich nicht mehr sein. Ich will nicht mehr Beckmann sein!

Er läuft hinaus. Eine Tür kreischt und schlägt zu. Dann hört man den Wind und einen Menschen durch die stillen Strassen laufen.

[16 dt. Hörspiele, pp. $146 \mathrm{f}$.

Taking the nonverbal elements in order, we must first test the girl's scream ("MAEDCHEN: schreit auf"). Borchert chose as part of the verbal code for the sound effect he had in mind a word that not only refers to the meaning of the sound (acts symbolically), but participates onomatopoetically in that sound. Through the use of such an icon (i.e., the "schreit") in his code for the sound effect, he engages in the perceptual process what I. A. Richards calls "tied" imagery. 8 The visual sensation of the words "MAEDchen: schreit auf" is accompanied in the mind's ear by an auditory image of a girl's scream. Thus we simultaneously apperceive the semantic meaning of the word as symbol and the acoustical image of the word as icon. The functions of this sound as icon (anxiety) and index (identification of the anxiety with the girl) are in fact served by the verbal code of the printed word.

The function of the next element, "und stürzt davon," is solely that of an index. The exact sounds used to convey this action are not critical (indeed, the retreating footsteps used in the production are all but masked by the scream), and the function is satisfactorily served by the meaning of the printed verbal code alone.

The next nonverbal sequence ("Eine Tür kreischt und schlägt $z^{\prime \prime}$ ) is much more interesting. Let us first consider the latter sound, as the shrill shriek of the closing door is omitted in the recorded production. The slamming, we saw, functions as an index, and as such is adequately served by the verbal code "schlägt zu." The more important aspect of the slamming door is its function as a symbol, which as the leitmotif of the work eclipses in significance 
the tertiary, iconic nature of the same sound. This is however precisely the function which words fill most naturally, since they already serve as symbols for their referents on the purely semantic level. It seems therefore logical that this symbolic function of "Tür

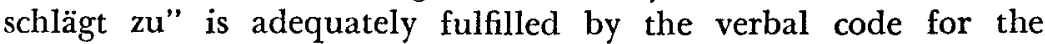
intended sound effect. The reason that the sound effect represented by the code "Tür kreischt" was not realized in the production probably rests with the principle of minimizing sounds that do not in some way support the semantic message of the Hörspiel. Were it realized, the shriek would probably function as an icon, without symbolic value, and would be redundant to the index function of "schlägt zu." We would probably feel the performance was justified in omitting it. Interestingly, its code in the co-text gives this sign an additional dimension-like "schreit auf," it carries with its verbal code a tied auditory image which produces an iconic effect in the reading process. Furthermore, this image in part mirrors the auditory image produced by the word "schreit," establishing a connection between the girl's reaction and the closing of the door which carries over into the symbolic dimension. Questions of appropriateness aside, in this instance the reader's experience is perhaps even richer than the listener's. ${ }^{9}$

The next nonverbal element specified in the text (in the co-text, actually) is the "'Teck tock' der Krücken." By analogy to the elements already discussed, the index and symbolic functions are seen to be satisfied by the semantic meaning of the words, and the iconic character of the sound effect by the onomatopoetic character of the verbal code "teck tock." 10

Thus far the verbal coding of the nonverbal elements in the text seems adequate for all three functions of these elements within the system of signs that comprises the message of the Hörspiel. This sort of sign-for-sign comparison could be carried out for most of this work and in fact for most of the plays of the classic era. From our review of the historical evolution of the use of nonverbal elements, we know that they were encouraged in the classic Hörspiel only insofar as they served to orient the listener (as indices) or as they contributed to the semantic level of the message (as symbols). Sounds were simply not used for their own sakes. Where sound effects function as icons, the author of Borchert's caliber will often sense the added importance of a tied acoustical image and organize his language onomatopoetically. Given the bias towards the communication of semantic meaning in the classic Hörspiel, the ade- 
quacy of the printed text is entirely logical.11 Moreover, it suggests that what the classic theorists were really concerned with limiting was not so much the use of acoustic signs, but the use of acoustic signals. For instance, Heinz Schwitzke cites the interesting case of a pre-war broadcast that called for thunderstorm effects in support of dialogue referring to the violence of the weather. A partial power failure eliminated the pre-recorded sound effects but permitted the live broadcast of the text to go on uninterrupted. A subsequent poll conducted by the station indicated that the sound effects were not missed. I submit that this case points not so much to the superfluousness of the thunderstorm sound effect, i.e., of the nonverbal sign, as to the redundancy of the acoustical signal for thunder. ${ }^{12}$

Confirmation of this interpretation may be seen in OttoHeinrich Kühner's note to his recent, yet fairly traditional, Pastoral 67 (1967):

Auch auf die Wiedergabe von Geräuschen wird in diesem Hörspiel verzichtet, was bei einem realistischen Hörspiel, das den Tagesablauf in einem Dorf behandelt, überraschen mag. Man hört weder Heugebläse noch Kuckucksruf. Die Geräusche sollen nur in dem Masse laut werden, wie sie im Text gesprochen werden. Dabei verlasse ich mich auf die Vorstellungskraft des Hörers, das heisst, ich vertraue ausschliesslich, wie man es beim Hörspiel tun sollte, auf die Realität der Sprache.

[Pastoral 67, p. 62]

Further confirmation may be found wherever acoustic events are present in the spoken text, but omitted in the co-text. An example would be the ending of Leopold Ahlsen's Philemon und Baukis (1955):

ERZAEHLER: Man hat sie unter den Bäumen begraben, an denen man sie aufgehängt hat. Sie unter der Linde und ihn unter den Eichenbaum. Die Äste verschränken sich, wenn der Wind sie zaust; und im Herbst, wenn das Laub zu rascheln anfängt, klingt es-wie ein leises Schimpfen. Und wie ein Weinen und Lachen zugleich.

[16 dt. Hörspiele, p. 72]

These preliminary considerations demonstrate that the verbal code of a nonverbal element may often suffice to evoke in the reader the acoustic image necessary for the realization of the poetic message. Any definite conclusion must await the demonstration of the following chapters in which the very different behavior of verbal and nonverbal elements in the modern experimental Hörspiel will be described. The tentative conclusion of this chapter implies only that the printed text of the classic Hörspiel may be in itself an adequate medium for the Hörspiel, not that the medium of radio 
20 / The Emergence of an Acoustical Art Form

or tape is in any way inferior to the text. This bears emphasizing, lest the reader of this paper wrongly conclude that I reject the value of actual acoustical realization of the classic Hörspiel. The preference one may feel for an acoustical realization over the reading experience is then like the preference one has for a particular realization of a drama, and varies with the work and with the production. I do suggest that the printed text of the classic Hörspiel be taken much more seriously, and that those who maintain that these works become a reality only when broadcast are perhaps deceived by their own enthusiasm for the genre. ${ }^{13}$ 


\section{NOTES}

1. Urged in 1925 by Carl Haensel (as reported in Krautkrämer, p. 25).

2. Phrase from Burghard Dedner, "Das Hörspiel der fünziger Jahre und die Entwicklung des Sprechspiels seit 1965" in Die deutsche Literatur der Gegenwart, ed. Manfred Durzak (Stuttgart, 1971), p. 133. Generalizing from Schwitzke's statement that the Hörspiel shows "den Willen nicht nur zu verstehen, sondern sich zu verständigen," Dedner proceeds: "Dieser Wille zur Kommunikation mit dem Hörer, zur Ubermittlung einer fassbaren Botschaft, erscheint in der Tat als eines der auffälligsten Merkmale der deutschen Hörspieldichtung in den fünfziger Jahren."

3. My sources for this distinction are Shannon and Weaver, esp. p. 9; and Max Bense, Theorie der Texte (Cologne, 1962) esp. pp. 13-23.

4. Which also helps explain why the pre-war experimental Hörspiel (which apparently explored the extent to which exclusively nonverbal elements could be meaningful) were not taken up again during the classic era. E.g., Fischer, p. 159: ". . . das Geräusch, naturalistisch oder stilisiert, eignet sich nicht als Mittler einer eindeutigen Aussage, obwohl man in der Frühzeit des Hörspiels mit reinen Geräuschmontagen eifrig experimentiert hat und es den Hörern überliess, zu erraten, welcher Art die einzelnen Geräusche seien und was sie bedeuten und im akustischen Nacheinander aussagen sollten." Apparently these early experiments are quite unrelated to the experiments of the $60 \mathrm{~s}$, although it is difficult to tell from the very limited information available exactly what their nature was. Depending upon the commentator's viewpoint, they can be made to sound either very modern or extremely primitive. Unfortunately, these experiments left few traces that have survived World War II. A comparative study of these experimental periods ought to be undertaken. See Schwitzke, Das Hörspiel, pp. 46-86, for the most generous historical sketch available, and his "Wertung und Wirklichkeit," Rundfunk und Fernsehen, 7. Jg., Heft 1/2 (1959), pp. 17-23.

5. E.g., Schwitzke, Das Hörspiel, p. 228: "Man kann als Grundsatz sagen: es gibt im Hörspiel keine Musik ohne eine Handlungsfunktion und kein Geräusch ohne eine Sinnfunktion für den thematischen Zusammenhang." And: "Uberhaupt muss, wer ein Hörspiel inszeniert, sich bei jeder Musik-wie auch bei jeder Geräuschverwendung stets fragen, ob sie nicht überflüssig sind."

6. Charles Sanders Peirce, Collected Papers (Cambridge, Mass., 1933), IV, 413 f. I am indebted to Max Bense, Semiotik, and Peter Schraud, "Theater als Information" for their elaborations on Peirce. This is but one of ten different triadic divisions of sign that Peirce develops.

7. By co-text I mean those parts of a drama's text that usually appear printed in italics, e.g. stage directions, speaker identification, etc. I am indebted to Roman Ingarden, Das literarische Kunstwerk, 3rd ed. (Tübingen, 1965) for this distinction. His terms are Haupttext and Nebentext. See esp. the appendix "Von den Funktionen der Sprache im Theaterschauspiel," pp. 403-428.

8. Richards (Principles, pp. $118 \mathrm{f}$.) posits six mental events which he argues are involved in reading a poetically organized text. These occur in the following order: I. visual sensation of the printed words; II. tied images; III. free images; IV. references; V. emotions; VI. attitudes. Esp. valuable for our analysis is the concept of tied images. Richards elaborates: "Visual sensations of words do not commonly occur by themselves. They have certain regular companions so closely tied to them as to be only with difficulty disconnected. The chief of these are the auditory image-the sound of the words in the mind's ear-and the image of articulation-the feel in the lips, mouth, and throat, of what the words would be like to speak." Events II through VI correspond to what I 


\section{2 / The Emergence of an Acoustical Art Form}

have called apperception. See Bartley's concept of "associative imagery" for support from perceptual psychology (Bartley, p. 450).

9. Speaking of co-textual material, Fischer makes an interesting admission: "Bisweilen wird aber der Regisseur vom Autor auch überfordert" (Fischer, $p$ 209). "Tür kreischt" is of course not such a case, but in both instances-either where a production omits material or is unable to interpret an author's intent acoustically-the reader of the text has more to experience than the listener. Naturally, opposite examples can be multiplied at will (and frequently are in those critical works written by producers) in which through the interpretation of the producer the listener has a richer experience. The ontological questions inherent in discussing works created in a convention normally calling for a performance are compounded unless it is made quite clear whether text or performance is involved.

10. Here again there is a variance between text and realization. In the latter, the sound effect accompanies the words "Teck tock" as they are spoken by Beckmann, not the subsequent co-textual reference. For the reader, tied images of the crutches accompany both textual and co-textual references. Through the director's interpretation, the listener is restricted to one reference.

11. Klaus Schöning suggests another factor which may have contributed to the adequacy of the text. In the days before the perfection of magnetic tape recording the production had to be carefully worked out in text form before the broadcast, as a continuous live performance allowed no correction or substitutions. Where this early dependency carried over into the classic period it may well have influenced the preparation of the text. See Schöning, "Hörspiel als verwaltete Kunst," in Neues Hörspiel: Essays, Analysen, Gespräche, ed. Klaus Schöning (Frankfurt a. M., 1970), p. 249. Hereafter, Essays.

12. Heinz Schwitzke, Das Hörspiel, pp. $218 \mathrm{f}$. The elimination of acoustical signals for nonverbal elements is only possible if there is sufficient verbal coding in the realized text, of course. Ernst Johannsen, writing on the various productions of his pre-war Brigadevermittlung (afterword to the Reclam edition, Stuttgart, 1967, p. 54), states that the attempt to broadcast the piece without sound effects "entwertet sofort das Stück." In Brigadevemittlung the nonverbal elements occur principally in the co-text.

13. Such a suggestion has been made before, e.g., Karl Marcus Michel, in an afterword to the anthology Spectaculum: Texte moderner Hörspiele (Frankfurt a. M., 1963). He notes with irony that the question "Warum eigentlich Hörspiele lesen?" is on the one hand made superfluous by the fact that they are read, and eagerly; on the other hand, it is made pertinent by the fact that the critical forewords to anthologies typically stress the traditional notion that the Hörspiel only truly exists in its acoustical realization. Heinz Schwitzke must be given credit for noting and championing the power of the word to convey tied images. In his book Das Hörspiel he says "Natürlich imaginiert das lebendige Wort mit seinen direkten Inhalten und zusätzlich durch die ihm vom Sprecher aufgeprägte Stimmung nicht nur Bilder, sondern auch Geräusche, genau so wie es Geruch, Geschmack und alle äusseren und inneren Empfindungen imaginieren kann" (p. 219). But note that he credits only the spoken word with this power. And this notion of a special sort of magic adhering to the spoken word, to the acoustically realized sound, persists, e.g. Schwitzke's introduction to Reclam's new Hörspielführer (1970): "Ganz offenbar geschieht die Evokation einer Welt eigener Geltung aus artikuliertem Wort, aus Geräusch, Musik und Vorstellung, also durch darstellenden Lautausdruck wesentlich intensiver als beim Lesen, wo die Augen stumm, als 'Schnellreiter' (Döblin), die Zeilen durchfliegen und die schlafende Sprache kaum flüchtig zum Leben wecken" (p. 12). 


\section{Nonverbal Elements}

\section{SOUND EFFECTS}

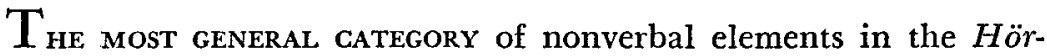
spiel is comprised of what we shall call sound effects. In this are included both natural sounds, such as the slamming of a door, and the more important class of stylized sound effects. ${ }^{1}$ The principle of stylization can convert any element, even the spoken word, to a sound effect; standard examples could be the modification of the human voice to suggest an animal's "speech" or the modulation of a train's characteristic sound to suggest passage through another level of reality. Ultimately the means of stylization can themselves become effects. The result is the creation of new sounds not found in isolation in our normal acoustical environment, such as "white noise" and the sound generated by sine waves.

As noted in the previous chapter, the use of nonverbal elements in general and of sound effects in particular diminished in the classic Hörspiel, even disappearing almost entirely in some types. Yet a significant measure of sound effect remains characteristic of those Hörspiele that seek to create an illusion of reality. Their role in the realistic Hörspiel has been described in the discussion of $\mathrm{Ge}$ räuschkulisse. In this section we want to examine the more important function of symbolic sound effects in the illusionistic Hörspiel for which it is most typical, the Hörspiel of poetic realism; and then contrast this use with the type of modern experimental Hörspiel for which sound effects are perhaps most important, the Schallspiel.

The Hörspiel of poetic realism remains the most interesting subcategory of the classic Hörspiel in its use of sound effects, in that characteristically a single sound is used symbolically as a leitmotif. Often the sound effect or its cause is reflected in the title. An early example is Eduard Reinacher's Der Narr mit der Hacke (1930), in which the recurring blows of a mattock symbolize a priest's lifelong atonement for once having stabbed a man. Ingeborg Bachmann's 
Die Zikaden (1955) features the stylized "Gesang der Zikaden" as a recurring reference to the empty hull one becomes by retreating from reality in self-deception and dreams. And Heinrich Böll's Klopfzeichen (1962) features the title sound in a thematic web involving Communion, communication, and existential confirmation.

The mere employment of an acoustical leitmotif has never been a sufficient guaranty of a good Hörspiel, however. When such a device is simply spliced into a story without adequate motivation or internal necessity, the result is an all too transparent gimmickan otherwise superfluous leitmotif tacked on to make a story seem more appropriate to its medium. An example is Erwin Wickert's Das Buch und der Pfiff (1949). The blank book (in which the heroine alone can read) is an effective device, connoting as it does an immersion in a world of fantasy and fiction, whereas the "Pfiff" that she alone hears merely adds an acoustically perceptible dimension to the book.

When well integrated into the essential fabric of the work, however, an acoustical leitmotif can be enormously effective. Since perhaps the best known representative of the classic Hörspiel, Günter Eich,2 frequently adopted this device, his very influential Träume (1951) are a logical choice for one pole of the contrastive analysis central to this section. Thematically, all the dreams are variations on a single theme: "Denke daran, dass du schuld bist an allem Entsetzlichen, das sich fern von dir abspielt-" (Träume, p. 155). The setting of each dream is a different nation, emphasizing the universal, almost existential nature of the responsibility Eich feels each of us bears for the plight of his fellow man. In four of the six dreams this theme is carried by a single sound effect. ${ }^{3}$ In these dreams at least the relationship between sound effect and poetic statement is fairly uniform, and each can be analyzed as an entity unto itself.

Eich's thematic technique in the Sixth Dream draws on the tension created when our everyday existence is thrown out of its accustomed focus. The civil servant and tax specialist Achmed Bayar dreams that he and his wife are forced to spend the night unexpectedly in a strange town after they have left their train before the planned stop. Bayar's dream begins with a confused jumble of sounds that prevents his dream self from sleeping. Angered, he tries to summon the chambermaid, but his ring produces only an unidentifiable noise like some heavy object falling. Receiv- 
ing the same response to his repeated attempts to summon the maid, Bayar decides to complain directly to the guests in the room above his own. To his amazement, he is received like a longawaited guest of honor. Over his protestations, he is given champagne, and soon finds himself accepting what seems like a harmless and profitable offer-for merely pressing a button, he will be paid a certain sum by the "Committee." Each time he presses the button, however, the unidentifiable noise recurs. Only after quickly earning twelve pounds does Bayar learn the source of this noise: "Ein Fallbeil." With each pressing of the button, someone has been executed. The party is over, and the Committee leaves, wishing its newly appointed Executioner an ironic "gute Nacht."

The inventory of sound effects is small, and may be quickly enumerated:

1. muffled, but penetrating noises ("Gast Es klingt wie ein Fest, als ob man tanzte. Stühle werden gerückt, es scharrt über dem Boden").

2. noise of a falling object ("Man hört ein Geräusch, als fiele etwas zu Boden.")

3. sound of door opening

4. sound of someone mounting stairs

5. sound of knocking

6. sound of door opening

7. festive clinking of glasses

8. sound of departing footsteps

These may be grouped into two general classes according to their function. Sounds 1 and 3 through 8 function primarily as indices, orienting us to the change of scene between hotel rooms and the departure of the "Committee" at the conclusion of the party. The dominant sound effect, number 2 , functions primarily as a symbolic sign and recurs throughout the piece as its leitmotif. It is the sound around which the dream is conceived and the riddle of its meaning is a key to the meaning of the entire piece. The sound of the guillotine activated by the pressing of a button is a metaphor for the impersonal and mechanical way destruction is perpetrated in the postwar world. On the most massive scale, there are associations with the horror of push-button warfare, while the metaphor speaks subtly on the smaller scale of everyday business transactions. The "Finanzbeamte" Bayar is appointed executioner because, in 
Kafkaesque logic, he is as responsible for the deaths of those around him as if he in fact had killed them. His dream gives him a momentary insight into his true essence and then dissolves, leaving his innocent existence unscathed.

The remarkable achievement in Eich's Sixth Dream is the extent to which it exploits the possibilities of the genre. Eich's figures are perturbed, confused, caught off balance by something they hear-a fact intended to increase the significance of what takes place for the listener. The action is constantly focused on the resolution of the uncomfortable situation in the opening scene. As it develops, the action is actually carried through sounds-the noise of celebration prompts Bayar to ring for the maid, the curious but unsatisfactory result of this attempt prompts the personal visit upstairs, the festive clinking of glasses leads to the summoning of the waiter for more champagne, which produces the mysterious noise again, and so on. In 1951 Eich was already demonstrating his sensitivity to and mastery of the special conditions of the Hörspiel, using sound effects to carry the plot instead of merely supplying acoustical material according to its demands.

But despite its excellence, this use of sound is merely the use of a convention and necessitates an actual acoustical realization no more than a poem cast in the convention of a ballad necessarily involves a singing performance. The basic organizing principle in this Dream is still the semantic meaning of the text. Since the work was conceived as a Hörspiel, the illustration of its meaning was accomplished in terms that could be acoustically presented. The thematic sound effect was selected, in other words, to help convey the meaning. It has a supporting function. No matter how thoroughly Eich integrates his theme and its formal expression, he has not made the acoustical signal necessary to its realization. The apperceived sign for the sound effect is necessary; the performance of that sound effect, its signal, is not.

This distinction is of central importance among the cluster of characteristics which distinguish the traditional Hörspiel from the most creative experiments of the $1960 \mathrm{~s}$. Because we will refer to it often, it may be helpful to formalize the distinction by labeling the use of sound in Eich's Sixth Dream (which is a vital, integrated involvement of the sign for a sound effect) as acoustical necessity. This term shall by no means signify a negative quality, but simply describes the level of acoustical involvement in the traditional Hörspiel. The sort of acoustical involvement achieved in the experi- 
mental Hörspiel, a necessary involvement of acoustical signals, we will call production necessity. According to their involvement of acoustical material, Hörspiele will demonstrate varying degrees of either acoustical or production necessity. Although it is not the only criterion, this involvement is important to our critical estimation of a work. Eich's Sixth Dream, for instance, seems unquestionably to have a higher level of acoustical necessity than his Second Dream, which curiously does not feature a similar thematic sound effect. We would not hesitate to rate this Second Dream stylistically weaker than the other five. 4 We want then not to deny the importance of the acoustical dimension for Eich's work, which in fact is considerable, but to understand its limits and to look for acoustical potential beyond that exploited here. Clearly, that potential exists. Though the sounds in Eich's Träume are organized for their impact on the ear, they are not necessarily transferred to our consciousness by acoustical signals, and may reach the ear (or "inner ear") as associative images of visually perceived signals. We are looking, then, for a Hörspiel in which the acoustical signal for a sound effect itself becomes necessary. Through such a work, we can perhaps see one aspect of the transition from acoustical to production necessity.

Paul Pörtner's Schallspielstudie I (1965) is an experimental Hörspiel in the fullest sense of the word. It was designed to test experimentally the limits of acoustic realization of poetic material. It differs from the sort of "totales Schallspiel" urged in 1961 by Friedrich Knilli in that verbal elements, and even the outlines of a traditional plot, are not abandoned. It is nevertheless one of the closest approximations of the Schallspiel yet produced. Called a study, it transcends such a modest description by the originality of its conception and the elegance of its execution. Neither has it been without echo, as later works by authors such as Peter Handke show indebtedness to its emancipation of sound effects from semantic domination. Yet it is enough like a study, in its clear progression toward its goal, to serve admirably as a model on which to demonstrate this emancipation.

The piece lasts in its entirety only about eleven minutes, and is comprised of four parts, actually of three variations on a basic scene. This scene features a combination of verbal and nonverbal elements knit loosely into a fairly conventional framework of speech and sound effects. The four nonverbal elements used are laughter, footsteps, the shattering of glass by a kicked ball, and dripping 
water. A woman, alone in her room, hears these noises and reacts to them. She counts the drops of water, trying to sleep; she listens to the approaching steps, wondering whose they are and whether they mean a visit; she is frightened by a breaking window and wonders anxiously about its cause. Her reactions grow gradually more hysterical until she can react only through laughter. ${ }^{5}$

The variations take this same material and manipulate it electronically. The first variation intersperses nonverbal and verbal elements in far freer fashion than in the base scene, but preserves the integrity of the units and the order of their original appearance. The second variation reduces the verbal elements to smaller fragments and surrounds them with nonverbal elements, so that the saturation of the verbal by the nonverbal is almost complete. By the third variation the boundaries between the various sound effects have become so indeterminate that the footsteps drip, drops burst like glass, and glass splinters giggle and laugh. The identity of the words is gonethey have become a fifth nonverbal element, all five of which are now combined in a rhythmically ordered kaleidoscope of acoustical forms. Pörtner describes the "Verschmelzung" achieved in this final version thus:

Die Tropfen beginnen zu sprechen, zu singen, die Tropfen schreiten, die Tropfen lachen, die Tropfen zerscherben; die Schritte tropfen, die Schritte singen, lachen, zerspringen gläsern zu Scherben, die Scherben lachen, die Scherben gellen metallen, das Lachen schlängelt sich wie ein stählernes Band, die Schritte grisseln körnig, werden zu Punkten in der wachsenden Stille, in die das Spiel ausschwingt. [Pörtner, "Schallspielstudien," in Essays, pp. $65 \mathrm{f}$.]

The aim of the experiment was to see how far this process could be carried while yet preserving at least overtones of the semantic orientation of the base scene. Despite the astounding variety of sound effects achieved in the variations, no new material is added after the base scene. Thus the masculine whispers that appear for the first time in the second variation are actually created by manipulation of the frequencies of the woman's voice in the base scene. In one sense, then, each variation "says" the same thing. Whether one agrees with the author that the abstract patterns of the final variation still contain a recognizable relationship to the themes of anxiety illustrated in the base scene, or feels that this relationship is last maintained in one of the earlier variations, is perhaps not very important. More important is that one recognize, in the stepby-step emancipation of nonverbal elements from verbal domina- 
tion, phases in which the nonverbal elements do in fact take over some of the semantic load of the verbal material; further, that such phases do not exhaust the creative potential of the sounds, which are taken beyond any semantic level until they function as discrete elements in free combination. In information-theory terms, the gradual decline in semantic information is paralleled by an increase in aesthetic information. The importance of this process for the emergence of the Hörspiel as a truly acoustical art form is enormous: sound, understood now as acoustical signals, functions here for its own sake, not as a sign for something else.

If we analyze this work in more detail, we see that the base scene is in many respects analogous to a traditional Hörspiel. It was recorded in a Hörspiel studio, using intentionally standard Hörspiel sound effects (Pörtner terms them "die verbrauchtesten, banalsten Hörspielgeräusche"). The verbal portion dominates the scene and yields, as has been sketched, the outlines of a traditional scene or plot. If the material were rendered in text form, the similarity to numerous Hörspiele of the traditional repertory would be unmistakable: ${ }^{6}$

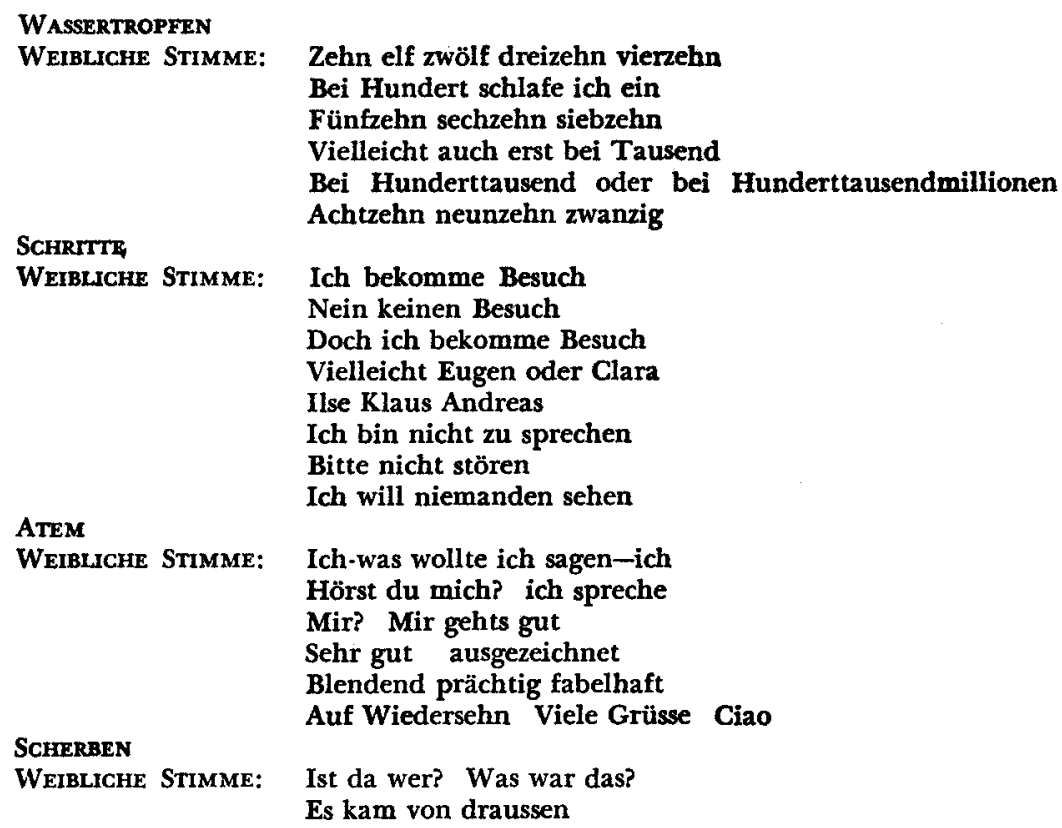




\author{
Es flog durchs Fenster herein \\ Ein Stein Nein kein Stein \\ Ein Vogel Nein kein Vogel \\ Ein Ball \\ Draussen spielen Kinder \\ Nein draussen spielen keine Kinder \\ Draussen regnet es \\ Es regnet ins Zimmer \\ Der Boden ist ganz nass \\ Das Wasser steigt \\ LACHEN \\ Das Wasser steigt
}

The nonverbal elements here are in fact adequately transmitted by the coded visual signals "Wassertropfen, Schritte, Atem, Scherben, Lachen." 7 Taken alone, these sounds are without semantic value. Pörtner could have devised a Schallspiel by distorting merely these nonverbal sounds. Yet this idea has little appeal for him: "Blosses Schallspiel ist ebenso abstrakt wie blosses Wortspiel" ("Schallspielstudien," Essays, p. 59). What makes this Schallspiel interesting is the context given these sounds by the addition of a semantic situation. In this situation the nonverbal sounds function initially as mere indices to the sound-reaction process. They acquire a semantic dimension in the base scene only gradually through association with the verbal text: the dripping acquires connotations of sleeplessness, steps become threatening, and the breaking of glass acquires connotations of fearful uncertainty which becomes a hysteria whose only expression is laughter. Sounds carry the "plot," to be sure, but these are codeable sounds. As in Eich's Träume, actual acoustical signals are not necessary for completion of the message.

Having invested his nonverbal elements with a measure of semantic meaning in the base scene, Pörtner tries in the first variation to maintain the semantic relationship between verbal and nonverbal elements while nevertheless reducing the number of words in favor of nonverbal elaboration. As the amount of verbal material is reduced, more of its semantic load shifts to the nonverbal elements. His technique involved isolating the elements of the base scene by recording each word and each discrete sound separately. Then by replacing words with other sounds, he achieved a saturation of his verbal material with nonverbal elements, thereby weakening the traditional opposition of this pair and preparing for the limited shift in semantic load from verbal to nonverbal vehicle. The intended saturation governed the choice of both verbal and 
Nonverbal Elements / 31

nonverbal material for the base scene, as it was desirable to have short, discrete signs which could later be interchanged without undue violence to a given rhythm. The rhythm adopted for the first variation is that articulated by the water drops in the base scene. The action in this first variation has the same order as in the base scene, that is, sounds and verbal message appear in the same four-part sequence: water / waiting; steps / visit; glass / guesses as to cause; and laughter. The four-part sequence is the base figure for the entire composition and determines not only the number of sounds and number of variations (three plus the base scene), but the basic number of electronic manipulations to which the material is subjected. The presence of this numeric structure (as an index), along with the preservation of the cause and effect relationship of the original plot, permits this first variation to be approximated by a text also:

\section{Geräusch}

TROPFEN

1. über Frequenzumsetzer

2. über Vocoden

3. Vocoderimpulse angesteuert

4. Filterkombinationen

SCHRITTE

1. über Frequenzumsetzer

2. über Vocoder

3. Vocoderimpuls über Filter

4. Shattereffekt

5. Vocoder mit weissem Rauschen moduliert

6. Vocoder mit sich selbst mod.

7. Filterkombinationen mit farbigem Rauschen moduliert

NAMENSCHLEIFE (Eugen-ClaraIlse-Klaus-Andreas)

1. über Vocoder

2. Vierfachmischung über Frequenzumsetzer

3. Wobbel- und Sägezahngenerator

SCHERBEN

1. über Frequenzumsetzer

2. mit Vocoderimpulsen angesteuert

3. über Zungeninstrument (d g i s h)
Stimme

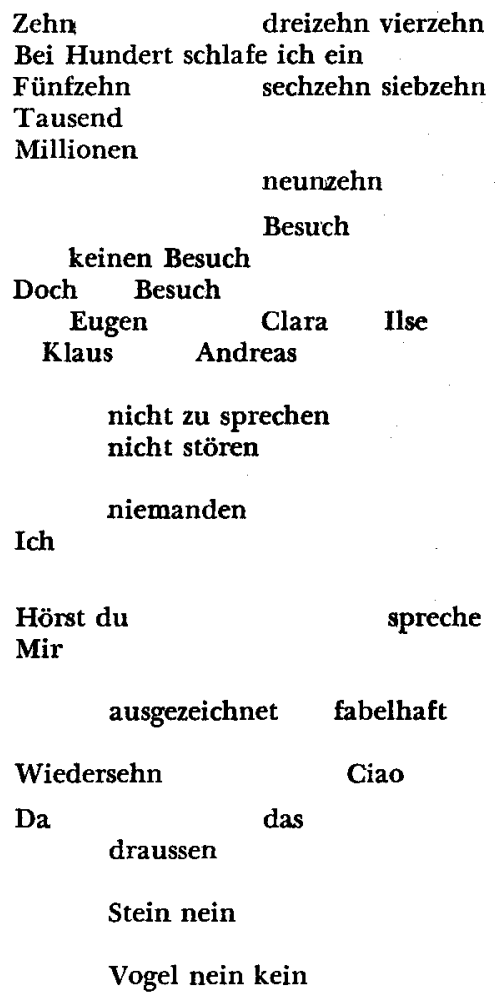


LACHEN

1. über Vocoder

2. über Hallgitter

3. Iteration

4. Frequenzumsetzer
Ball

Draussen

Draussen

Das Wasser

steigt

It must be emphasized that Pörtner does not offer this description as a text. Speaking of his creative process, he says "Hörspiele werden am Schreibtisch entworfen, aber im Studio gemacht." 8 While such a description may in fact suffice to convey the semantic message involved, clearly there is more going on in this first variation than the preservation of the semantic dimension despite a reduction in word stock. In part the semantic level is preserved because the verbal elements which have fallen away are largely the function words, while nouns and verbs are better retained. In part it is because the original and familiar character of the four sound effects is still recognizable. Familiarity, as was pointed out before, is a crucial part of the semantic dimension of communication. For these reasons we sense not so much a loss of comprehensibility in this variation as a compacting of the information in the base scene.

What makes this variation more dependent upon actual acoustical signals is the introduction of a different organizing principle in the elaboration of the nonverbal material. Had Pörtner wanted to stay with a verbally codeable work he could have carried out this elaboration by assigning his sound effects a symbolic role. This would have been to merely substitute a new semantic dimension (based on sound symbolism) for the original (based on verbal material), as in fact often occurs in the classic Hörspiel. Instead, Pörtner reorganizes his materials to uncover their inherent rhythmic and tonal qualities-aspects of the material which had always been present, but which were masked by more familiar and hence readily apperceptible features (i.e., lexical content of words, initial naturalness of sound effects). Involved in this restructuring is then a distortion of the familiar, a making strange or "Verfremdung." This venerable aesthetic principle supports the information theory postulate that aesthetic information depends upon the occurrence of the unexpected rather than the predicted, and finds here merely a new focus on the raw materials of acoustical events. Instead of the psychological alienation to which we have become accustomed through Kafka, the Theater of the Absurd, and Brecht, Pörtner makes acoustical events strange by deforming their actual acoust- 
ical properties. In so doing he brings to the surface latent acoustical qualities inaccessible except through technical, mainly electronic, manipulation. The use of electronic and mechanical devices for the manipulation of sound, as in Pörtner's work, is often fundamental to the experimental Hörspiel and not infrequently the measure of its production necessity.

The shortcomings of the textual rendering of the first variation rest then upon the shift in emphasis from the communication of semantic to aesthetic information and the involvement of instruments for the creation of sounds not found in our normal acoustical environment. Even if the technical devices referred to were familiar to the reader, the mere notation of, for instance, the use of the Vocoder is not sufficient to communicate the aesthetic information involved in that use. Compare "Schritte: 1. über Frequenzumsetzer 2. über Vocoder" with this co-textual reference from Claus Hubalek's Die Festung (1956): "Schweigen. In das Schweigen dröhnen von draussen näherkommende Schritte. Die Schritte einer Kolonne" (16 dt. Hörspiele, pp. 129 f.). The traditional code for the traditional illustrative or symbolic use of sounds suffices to generate the required image. But the verbal code for the distortion of sound produced by instruments such as the Vocoder and frequency filter is inadequate as a stimulus for the imagination. Apperception would be limited to the comprehension of the fact of distortion. With decreasing emphasis upon the semantic message, the codeability of the signals through traditional verbal signs also decreases; a coded, i.e., semantic verbalization of the nonverbal element is no longer sufficient because the nonverbal element no longer serves only a semantic function.

The second variation carries this shift one step further, in that the integrity of the word is violated, reducing many of the verbal elements to little more than scraps of sound. If such a description seems negative, it is only because of our bias toward a semantic level. A semantic dimension persists, but to a significant extent aspects of the nonverbal elements have become its vehicle. For example, the counting words no longer issue from the expected "verbal" vehicle, the woman's voice, but have moved closer to the nonverbal realm through the acquisition of the strong rhythm of dripping water. From here to the last variation, in which the drops "speak," is a small step. Similarly, the sentences "Es regnet ins Zimmer" and "Der Boden ist ganz nass" are supplanted by the new positioning of the sound of dripping water next to "Das Wasser steigt." 
In addition, this variation demonstrates that the distortion or rendering unfamiliar of sounds is not a destructive process. Although no new material is added, entirely new acoustical forms are created. For instance, out of the steps is created an almost musical melody with a distinct movement up and down the scale. Each of the nonverbal elements begins to explore its freedom from semantic domination in this way and each has its characteristic melody and rhythm.

In the last variation, we see a maximization of the process described so far. Now the identity of the verbal material as speech is extinguished. The musical quality of the nonverbal elements is perhaps all that remains-a rhythmically structured interplay of sounds. Whether one still finds semantic overtones is the question Pörtner leaves us with:

Wenn ich mich von der sprachlichen Aussage entferne und mich dem musikalischen Ausdruck nähere, wo überschreite ich die Grenzen des Hörspiels? Verdichtet oder verflüchtigt sich der Gehalt einer Szene in der Abstraktion? Gibt es Schallereignisse, die so plastisch und suggestiv sind, dass sie mehr als blosser Schall ihre eigene Sprache sprechen? Diese Fragen bezeichnen die Perspektive, in der dieses Experiment angesetzt war.

[Pörtner, MS]

The answers must be found by the individual listener and will depend upon whether each variation is considered separately from the progression. Clearly there is far more sense of "Verdichtung" and far more awareness of the structuring principle involved if one listens to all three variations in sequence, than if only the base scene and any one variation are compared. Listened to alone, the fourth variation is not likely to be distinguished from electronic music, and with good reason, as this was the aesthetic model for the work's development. ${ }^{9}$ But the Schallspielstudie $I$ is more than just the last variation. It is a unified work and must be considered as the entire progression through base scene and all three variations. And seen as a progression, the work gives us a new perspective by which to judge acoustical involvement in the Hörspiel. Step by step the variations ascend the scale of acoustical necessity until the acoustical signal itself is involved and production necessity is achieved. The progression moves from the base scene, which because of the redundancy of acoustical signals occupies a relatively low position, to the second section, where a text is possible but wholly insufficient, to the third, where the acoustical quality of the signal is almost more important than the apperceived sign, 
to the fourth, in which the signal alone contains all the information of the message. Sign and signal have become identical. The result is a Hörspiel without a text, a Hörspiel that exists only in its acoustical realization.

Writing in 1964, just one year before Pörtner's initial Schallspielstudie, E. Kurt Fischer speculated in more positive fashion than most theorists about the untapped possibilities of nonverbal materials in the Hörspiel:

Man kann sich noch manche Spielart der Geräuschverwendung vorstellen, das Geräusch als Interpunktion etwa. Geräusch als die grosse Flut, in der das nicht mehr sinnträchtige Wort ertrinkt, das Geräusch als Kontrapunkt zur völligen Stille. Selbständig, Alleinherrscher darf es höchstens für ein paar Sekunden werden, und es muss immer etwas auszusagen haben. [Fischer, p. 144]

As we have heard, the Schallspielstudie $I$ fulfills these speculative uses and goes beyond them, in that it opens a possibility ruled out by Fischer's last qualification. Sounds need not convey semantic information to function creatively in a Hörspiel. A world of acoustical events surrounds us, a world no less real than the worlds of visual or mental events, but a world requiring new artistic approaches for its exploration. Pörtner finds one approach in an expanded sense of language:

So verstehe ich unter "Sprache des Hörspiels" nicht die im Hörspiel gesprochene bzw. vom Hörspielautor geschriebene Sprache, sondern die mannigfachen Methoden der Erschliessung und Formgebung der akustischen Sphäre, die nicht im Wörtlichen aufgeht, aber auch nicht die wörtliche Sprache ausschliesst.

[Pörtner, Akzente, p. 77]

The "Methoden der Erschliessung" to which he refers involve electronic and mechanical devices whose ability to deform the acoustical qualities of everyday sounds permit them to function as a sort of grammar for this new "Sprache des Hörspiels." But can we say this new sense of language with its sometimes totally new form and function still involves literature? This is a difficult and perhaps unanswerable question. As Peter Hirche once wisely remarked, there are simply too many different views as to what constitutes literature for an absolute answer. ${ }^{10}$ An inability to fit such a phenomenon into one of the customary literary molds may only point to the inadequacy of these molds. In a sense our comparison of the behavior of sound effects in the old and new Hörspiel has already 
discovered elasticity in molds others have found too rigid. With the perspective of Pörtner's Schallspielstudie I we can see more easily how Eich's Sixth Dream, for all its acoustical necessity, is unquestionably literature. By adopting the genre of the Hörspiel, Eich placed certain constraints upon his material. These conventions were developed with the requirements of the listener in mind. The reader may not share these requirements; he can nevertheless value a work that meets them. For example, the reader may not need the convention of a restricted scope of action in the same sense that a listener does, but he can appreciate the tautness such focus brings to poetic statement as fully as that listener. Similarly, the reader can feel the tension between the mysterious sound in this piece and the riddle of its source as keenly as the listener; the reader need form no particular image for the sound since this tension depends upon the initial ambiguity of the noise. An exact acoustical image is irrelevant. Even the effect of the climactic identification of the source of the sound is not inaccessible to the reader, although some critics would object that a reader does lose the "particular quality of unexpectedness" since "our eyes are trained to look ahead."11 While this may be valid for the element of surprise, which has only a single, unrepeatable effective moment, what functions in this work is rather the tension between a certain frame of expectation and the threat of its inversion. Such a tension bears repeated exposure. It may be accompanied by, but does not depend upon, surprise. To argue otherwise is to declare an unconscionably large body of written literature aesthetically obsolete after an initial reading.

We must of course look to a different mold for a literary precedent for Schallspielstudie I. And in fact the twentieth century has not left us entirely unprepared for such an expanded sense of literature. The whole thrust of the Sprachskepsis first articulated in Hugo von Hofmannsthal's Chandos letter of 1901 ("Ein Brief," Gesammelte Werke, Frankfurt a. M., 1951, 12, 7-22) sought to penetrate a language that had ironically become a barrier to the poetic communication of reality. Whereas Hofmannsthal's Chandos sees no solution save silence, Rilke's Malte Laurids Brigge, finding his language useless as an approach to the objective world, lets its acoustical sphere speak its own language:

Elektrische Bahnen rasen läutend durch meine Stube. Automobile gehen über mich hin. Eine Tür fällt $z u$. Irgendwo klirrt eine Scheibe herunter, ich höre ihre grossen Scherben lachen, die kleinen Splitter kichern. ${ }^{12}$ 
Of course such examples of dissatisfaction with traditional literary expression fail to convince precisely because they are such eloquent statements of the problem. More convincing are the efforts of sound poets like Hugo Ball who sought to renew the expressiveness of language by experimenting with the sound and rhythm of verbal material exclusive of meaning. This is in turn only one of the roots of the movement known as concrete poetry. Here too, the acoustical sphere of reality gives important impetus to literature. To convey the reality of trench warfare, Ernst Jandl surmounted limitations of normal poetic language by exploiting this sphere in his poem "schtzngrmm." 13 Using as his material only consonants from the word Schützengraben, he reconstructs the sounds of the battlefield, "concretizing" the reality which the abstract symbol of the word can only denote. At the same time he elicits through his manipulation of the verbal material connotations latent within the word but never realized in normal usage, e.g., "grrrmmmmm" ( $=$ Grimm) and "t-tt" ( $=$ Tod $)$.

Such a poem brings us to the same point, where our traditional feelings about literature discourage an interpretation of a work that may in fact rely upon an oral performance. Yet because a concrete poet such as Jandl finds verbal signs for the acoustical events he seeks to convey, we are still more comfortable calling a poem like "schtzngrmm" literature than we would be if Paul Pörtner set about treating the same material with like purpose but with his very different techniques.

Probably this is a state of awkwardness which we must tolerate unless we want to arbitrarily restrict "literariness" to those depictions of acoustical events capable of transmission through verbal forms. This is a reasonable and attractive approach, for otherwise the boundary between literature and music may dissolve completely. Yet the very appeal of a clearly defined boundary may pose a substantial threat to a better understanding of both literature and music, and consequently of the Hörspiel. Clearly this boundary is crossed at some point in Schallspielstudie I. Such fluidity is another fundamental characteristic of the new Hörspiel and will occupy us again in the following section on the behavior of music as a nonverbal element.

A more cautious approach to the problem of "literariness" would be to wait for the development of a more adequate code for Hörspiele which we feel now are uncodeable experiences. Certainly there are efforts in this direction, and in discussing other 
examples of the modern experimental Hörspiel we will have a chance to assess their adequacy. Each of the nonverbal elements provides a separate challenge to the general problem of coding. There will be some unavoidable overlapping, as we have seen in the present section, between sound effects and music. The main task in this section was to contrast the roles of sound effects in the old and new Hörspiel, and through this contrast to illustrate some aspects of the emancipation of the acoustic dimension from the semantic function. In this process we encountered other related characteristics of the experimental Hörspiel, including the new importance of electronic manipulation of sound and the breakdown of traditional genre boundaries. As a result we see more clearly than before that literary criticism is well equipped to deal with even those classic Hörspiele organized thematically and formally around sound effects; on the other hand we have met in the Schallspiel one type of modern experiment which raises complex questions about the ability of literary criticism to deal with this genre as it approaches a truly acoustical art form.

\section{MUSIC}

Like sound effects, music has traditionally played a subservient role in the Hörspiel. Probably its most common function has been as an index. The index can be to settings (Chinese temple, modern city), moods (joy, sadness, suspense), or changes of scene (e.g., "curtain" music). Occasionally a known composition was used for these effects, as when Peter Hirche specifies certain sarabands by Bach and Reusner and an aria from a work by Ferdinand Ignaz Hinterleitner for his Nähe des Todes (1958). Usually, however, the exact nature of the music used as an index was left to the studio composer and will therefore vary from production to production. Walter Jens begins his Ahasver (1956) with the simple co-textual direction "Ganz weit weg, leise und bestimmt, Orgelmusik. Stimme des Pastors am Grabe einblenden." And Leopold Ahlsen specifies only "Musik: Melodie einer Hirtenflöte" to set the desired tone for the opening of his Philemon und Baukis. This casualness does not mean that the musical elements are irrelevant, but only that the author is content to indicate the effect desired and rely upon the sensitivity of the director and composer for an adequate realization. There is in fact so strong an identification of mood and setting with certain instruments (e.g., with shepherd pipes, organs, violins, 
drums, etc.), that simply naming them frequently suffices to communicate the desired orientation. ${ }^{14}$ The associated acoustical images of the verbal code for the instruments involved may suffice to evoke in the reader the effect of the acoustical signals in a performance. Where the mere naming of an instrument would still be ambiguous, a simple modifier such as "martial," "tender," or "threatening" provides the required guidance for both studio composer and reader alike to fashion the appropriate music.

Even Heinz von Cramer's very elaborate and imaginative use of music in Die Ohrfeige (1959), where instruments carry on a conversation with the protagonist, remains within the codeable index function. As the author explains in a co-textual note, the function of this music is to maintain a level of reality "stets haarscharf zwischen Traum, Rausch und Wirklichkeit":

'TAUBE: Wo bleibt denn der Klare - und doppelt, ja!

Der Trommelwirbel schwillt etwas an.

Ich sage euch, ihr habt ganze einfach Angst.

Ein schöner Stammtisch das - Angsthasen, Memmen, einer wie der andere - He, Wirt!

Ein Fagott macht ein paar strenge, mahnende Töne.

Was?

Das Fagott wiederholt seine Mahnung etwas stärker.

Das verbitte ich mir! Ich trinke, soviel ich

Lust habe, verstanden - Sofort meinen Klaren hierher, aber dalli, Herr!

Drei Klarinetten in einem kurzen, beschwörenden Kanon.

[16 dt. Hörspiele, p. 353]

The differentiation of realities is clearly sustained in the text and the unique "conversation" brought adequately to life in the imagination of the reader through the combination of the associated images mentioned above and the use of descriptive modifiers like "mahnend" and "beschwörend" (which may in fact give the reader a more articulate version of the conversation than is available to the listener).

Occasionally the classic Hörspiel not only used music as an index, but also involved it symbolically in the action. Ingeborg Bachmann's Die Zikaden has already been mentioned in this connection. Here again, however, the symbolic effect of what she specifies as "nicht mehr menschlichen, wilden, frenetischen Gesang" is communicated at least as well by her text as by the actual acoustical stimuli of a production. In fact, to ensure that the symbolism of 
the music is accessible to the listener, the author has it described by a narrator:

ERZAEHLER: Es erklingt eine Musik, die wir schon einmal gehört haben. Aber
das ist lange her. Ich weiss nicht, wann und wo es war. Eine Musik ohne
Melodie, von keiner Flöte, keiner Maultrommel gespielt. Sie kam in Sommer
aus der Erde, wenn die Sonne verzweifelt-hoch stand, der Mittag aus seiner
Begrifflichkeit stieg und in die Zeit eintrat. Sie kam aus dem Gebüsch und den
Bäumen. Denk dir erhitzte, rasende Töne, zu kurz gestrichen auf den ge-
spannten Saiten der Luft, oder Laute, aus ausgetrockneten Kehlen gestossen-
ja auch an einen nicht mehr menschlichen, wilden, frenetischen Gesang müsste
man denken. Aber ich kann mich nicht erinnern. Und du kannst es auch nicht.
Oder sag, wann das war! Wann und wo?
[Fischer, Hörspiele, p. 80]

But of course Hörspielmusik is not synonymous with melody. Its range includes the use of a single dominant tone as a leitmotif (Eich's Fis mit Obertönen) as well as the fully orchestrated passages that integrate the action of many realistic plays. It appears as a device (in American terminology, a "stinger") to underscore certain dramatic moments. The repetition of single notes may function to indicate the passing, acceleration, or retardation of time. It may also be used to stylize other sound effects, in which case its identity as music may not even be perceptible. The capacity of the studio orchestra for overcoming unwanted naturalism in other sound effects is an important aspect of music for the classic theorists. ${ }^{15}$

Many of these latter uses of music involve largely performance problems. The problem of stylization for instance is eliminated for the reader of the text, who already experiences the indicated sounds within a framework of aesthetic distance. Since the contributions of this sort of music (which often are not even specified in the text or co-text) are interpretive and are tied to a particular performance, we would not want to say they constitute a significant measure of acoustical necessity. On the other hand, works like Bachmann's Die Zikaden and Heinz von Cramer's Die Ohrfeige involve music structurally and thematically. Such works do gain a measure of acoustical necessity from music, in that the signs for the musical elements are necessary to the completion of the message of the Hörspiel. Yet these elements, both as index and as symbol, are easily codeable in the printed text. A reading will not duplicate the experience of a particular realization (unless through memory of a previous hearing), but since the music is semantically organized in accordance with the dicta of the classic theorists, ${ }^{16}$ actual acoustical signals are not required for these musical elements to make their contribution. 
As we have already seen in Pörtner's Schallspielstudie I, music in the modern experimental Hörspiel transcends this subordinate function. Hörspielmusik becomes "Musik als Hörspiel."17 Since this transition has in some instances made it impossible to distinguish the two absolutely, it is perhaps wiser to view their boundary, with Helmut Heissenbüttel, as less a dividing line than a string of points at which the Hörspiel and music now coincide. ${ }^{18}$

In its independence, music participates in the organization of the modern Hörspiel in at least two new ways. The first is the tendency to organize acoustical material according to what are normally considered musical principles. The assertion (Fischer, p. 237) that the classic Hörspiel is "akausal wie die Musik" seems essentially meaningless because music has its own laws, its own causality. Moreover, even the most poetic of classic Hörspiele were predicated on the operation of semantic causality. There were of course features apart from the direct use of musical instruments which are sometimes thought of as being "musical." These include the extensive use of repetition, stanzaic insertions of songs or rhymed passages, choral delivery of dialogue or commentary, etc. The "lyric" Hörspiel of the late fifties and early sixties makes excellent use of such devices, and while these works do often involve a greater degree of acoustical necessity than the Hörspiel of poetic realism, it is more accurate to ascribe this increase to lyricism than to musicality.

It would be meaningful to say of the experimental Hörspiel, however, that its organization of materials often involves the causality of music. A musical ordering of events can be achieved electronically, as in Pörtner's Schallspielstudie I, through the precise manipulation of frequency, amplitude, timbre, and duration, with the result that it becomes indistinguishable from electronic music. It can also be achieved without electronic manipulation, by supplanting semantic patterns with patterns of rhythm, tone, and interval, with the original identity of the sound effects, music, and words retained. Between these poles lies a rich range of possibilities.

An example of the latter use of musical organization is found in Ferdinand Kriwet's One Two Two (1969). Essentially a montage of famous voices, recorded song fragments, and studio-concocted verbal exchanges, this work could be considered musical, if only by virtue of the large body of actual music involved. Approximately one-third of the material consists of recognizable fragments from popular songs by Paul Anka, Heintje, Elvis Presley, Frank Sinatra, 
and others. In addition there are the frenetic and sometimes melodic expressions of Radio Luxemburg disc jockeys, the singsong patter of tobacco auctioneers, and the driving chants of Indian cult dancers. But this work is musical also in that even the nonmusical material, including short but recognizable sections from addresses by political, religious, and public figures from several countries, is often organized according to its rhythmical or tonal properties. A rhythmical arrangement is sometimes achieved by the isolation and reduction of words to individual sounds. These minimal acoustical events are then spliced together in alternation with other fragments, much as Pörtner did in the first variation to Schallspielstudie I, but with markedly different results because of the difference in raw materials. For example, two words from the "Battle Hymn of the Republic," glory and halleluja, are reduced to "glory glory hale"," then further reduced to the sounds of long $O$ and $R$, which when repeated and mixed with segments from other material achieve a new rhythm and melody. The original melody accompanying these sounds is itself freed, in this process of reduction, to appear later in another historical context (as a musical quotation from a Barry Goldwater campaign song). In the meantime, the sound of the long $O$, its semantic value reduced to a minimum, is free to function as an essentially musical link in sequences joining a rock song (Oh, in the sky), a phrase by Stan Freberg (Oh Marsha, Marsha), a Christmas carol (Oh come all ye faithful), and a language lesson (Oh, do come in).

The musicality of sequences such as the one described above is manifest in the author's renotation of the acoustical realization. Renotations, or texts made in accordance with a given acoustical realization rather than as a guide to subsequent realizations, are symptomatic of the sequence of development for works demonstrating production necessity. Kriwet's renotation is unusual, in that he uses an expanded form of the musical staff to record these events, listing not every word or sound, but typically identifying the onset of a particular source material. Simultaneous material is stacked vertically like a chord, and the duration of each element is given in seconds. Accompanying many of the elements are musical codes for various tempi and volume changes $(m p, p p$, $f$, etc.) as well as directions for performance of speakers in the studio ("path." = pathetisch, "hyst." = hysterisch, etc.), and instructions for mechanical or electronic manipulations. 
Comparison of the text (included in the anthology Neues Hörspiel, edited by Klaus Schöning) with the acoustical realization reveals on the one hand the necessity of unorthodox notation, and on the other the limits of any text to convey the experience of this Hörspiel. Despite its resemblance to a musical score, the renotation is only a guide to the acoustical realization and cannot itself generate a performance. Musical transcription is sufficiently well developed that some musicians claim to be able to "sight-hear" a score. The material in One Two Two, although highly musical, is so mixed with events for which there is as yet no adequate code that reading its "score" is not a genuine alternative to the experience of the production. It can deepen this experience, it can perhaps suggest still other ways for the material to be presented, but it cannot approximate the acoustical experience itself.

The second function music engages in the experimental Hörspiel is as innovative as the musical structuring of events. It involves the use of music as an icon. The common denominator of the bulk of the material in One Two Two is its icon-character: practically all of the material was originally delivered orally. This delivery is a vital part of the message; the material heard represents its own original delivery and participates in this delivery by virtue of its concretization as an acoustical quotation. Remove the icon character, dispense with the realization, and the Hörspiel (as text) reverts to a continuous sequence of song and speech fragments indistinguishable from the unsung, unspoken texts of the original songs and speeches. Although the renotation reveals patterns of semantic significance, such as the association of Hitler with the Church and the conservative political party of Franz Josef Strauss, these associations form but the surface level of meaning in the work. Kriwet is concerned with more subtle patterns. $\mathrm{He}$ is primarily concerned with the capacity of spoken language for communication. By comparing various expressions, in German and English, he builds patterns that do or do not achieve effective communication, measured at the basic level of establishing contact. In one sense One Two Two is a demonstration of the communicative poverty of certain types of language, and the richness of other types. The richest types are the spontaneous sounds of a Happening, of the Beatles, of Frank Zappa, or disc jockeys, sports events, and political demonstrations. In comparison to these, the eloquent and weighty statements of political and religious leaders seem inadequate exercises in the art of reaching people. 


\section{4 / The Emergence of an Acoustical Art Form}

The conclusion Kriwet would have us draw from this demonstration is that to reach people, to truly communicate, spoken language ought to feature less the polished formulae of written communication than the infectious rhythms of rock music. The contrast is not a simple one of musical versus non-musical expression. Some music, perhaps because it has become a cliché through constant repetition (e.g., Christmas carols), falls into the category of non-expressive communication. On the other hand, some quasimusical expressions abound in the dynamism of music (e.g., discjockey slang, auctioneer patter). The most effective material for this demonstration is taken from the speeches of Adolf Hitler. The remarkable rhythms of his speech ally it unmistakably with the infectious musical and quasi-musical elements of effective communication. The contrast afforded through sequences of speeches by other political and cultural leaders reveals a great deal about the effectiveness of Hitler's rhetoric. A textual reading of these passages could of course evoke certain of these associations, but it would be completely insensitive to the basic problem of the work, the demonstration of the relative impotency of some very important forms of language communication. In some cases in fact the semantic association (Hitler / Church / Franz Josef Strauss) can conflict with the iconic patterns (which oppose Hitler to the other two on the basis of their delivery). Only an acoustical realization of the work gives acoustical icons the freedom to interact equally with semantic signs.

Schallspielstudie I and Kriwet's One Two Two illustrate two of the more significant new uses of music in the experimental $H \ddot{o} r$ spiel. What saves these works from abusing the latitude in Karlheinz Stockhausen's statement "Sprache kann sich Musik, Musik kann sich Sprache nähern bis zur Aufhebung der Grenzen zwischen Klang und Bedeutung," 19 is the strict organization of their respective materials. This organization varies from a more traditional cluster of melodies, harmonies, and rhythmical beats to the new categories of formal organization permitted by electronic devices for the control and generation of sounds. Kriwet heard in some music a potential for communication that was missing from other and doubtless more important messages. He demonstrates this potential through musical quotations which function as icons, representing what they already are-examples of musical delivery. Both Kriwet and Pörtner involve music in the conversion of other 
elements, and eventually the entire Hörspiel, into a musical composition. The use of musical quotations as icons has been developed in pieces such as Wolf Wondratschek's Paul, oder die Zerstörung eines Hörbeispiels (1969) and Mauricio Kagel's (Hörspiel) Ein Aufnahmezustand (1969). The use of musical principles to organize nonverbal, and especially verbal, material to better free it from semantic associations has received even wider attention. Both uses share finally in a new appreciation for the unique pleasure that an acoustical art form can provide, and contribute strongly to it. This is a pleasure formerly confined mainly to music per se. Now, with the musical rendering of other elements and the inclusion of music for its own sake as a sign equal to words and sound effects, this musical pleasure becomes one of the most important characteristics of the modern experimental Hörspiel. As Kriwet says, "Das sinnliche Hören sollte einen gewissen Lustgewinn erbringen." 20 The incorporation of this dimension of pleasure as an organic principle might well be considered a third use to which music is put in the experimental Hörspiel.

\section{DIMENSION}

In considering the role of dimension as a nonverbal element, we must differentiate between its spatial and durational aspects. On the one hand, the acoustical properties of what we hear change as the action in a Hörspiel shifts, for example, from factory to seashore. Such changes are one way of orienting the listener and illustrate one possible function of the spatial dimension. On the other hand, the action of a half-hour's Hörspiel may focus on as little as five seconds or cover a lifetime; such manipulation of time is a common aspect of the durational dimension.

Like the other nonverbal elements, dimension was subordinated in the classic era to the semantic level of the message. Speaking of the spatial dimension, Heinz Schwitzke said, "Raum im Hörspiel ist . . . nichts als eine Akzidenz, eine Farbe, die dem Wort oder den Tönen aufgeprägt wird und die ihnen dann anhaftet" (Das Hörspiel, p. 214). His observation was correct, but the implication that dimension, as a function of something heard, is a priori acoustical ignores the distinction we have drawn between apperception and perception. If we agree that the term "something heard" could apply to apperceived signs as well as to perceived signals, we see that the spatial dimension too, the very "acoustics" of a Hörspiel, may perhaps be conveyed by the printed text. 
The most common use of this dimension in the classic Hörspiel was to provide acoustical properties consistent with the scene of the action. Recording in studios of various sizes and equipped with various acoustical properties, or electronically introducing echo or "telephone" quality, facilitated the illusion of an identifiable setting. In the Hörspiel of poetic realism the spatial dimension sometimes becomes thematic, that is, the acoustical properties of the sounds are promoted from index to symbol. An example of such thematic use is found in Günter Eich's Die Andere und ich (1952). Spatial dimension in this work not only helps to define the scene of the action, but becomes a part of that action itself. The story of Ellen Harland's visit to an impoverished area of Italy occurs on three poetic levels, each characterized by a dominant spatial dimension: the level of reality, in which Ellen is an American tourist in Italy (spoken in an open dimension); the level of poetic reality, in which she is trapped in the identity of an Italian peasant woman (spoken mainly in the confined dimension of peasant huts); and the narrative level, in which Ellen comments upon the meaning of her experience (spoken in absence of any spatial characteristics, i.e., "raumlos").

Equally interesting and persuasive thematically is the avoidance of any sense of spatial dimension. Peter Hirche's Die seltsamste Liebesgeschichte der Welt (1953) relies for much of its effect upon a carefully maintained ambiguity of time and place. Despite reference to various locations, the principals are sometimes unable themselves to determine whether or not the experiences they share occur in the same time or space frames. This ambiguity must be preserved for the listener:

SIE: Ich spreche mit dir, weil ich jetzt gerade sehr glücklich bin.

ER: Wegen der Tänzerinnen.

SIE: Und wegen der Musik. Und wegen . . . ich bin glücklich. Nur etwas fehlt. ER: Nichts fehlt. Ich sitze neben dir.

SIE: Aber in einem anderen Theater, in einer anderen Stadt, zu einer anderen Zeit.

ER: Vielleicht.

[Sprich, p. 138]

This ability of the Hörspiel to leave questions of spatial dimension open by simply avoiding acoustical characterization of scenes is, as the classic theorists claim, a considerable aesthetic advantage over film, stage, and television, especially for those plays that feature an inversion of our normal sense of time and place.21 But it 
is not demonstrable that this ability to suspend our sense of spatial dimension is missing from the printed text. As long as dimension remains "Akzidenz," its function as index or symbol is subordinate to the semantic message and finds adequate codification in the printed text.

The same limitations apply to the use of the dimension of time. The potential for telescoping or compressing time, for montage techniques which bring into contrast different time periods, and for effortlessly blending scenes across intervals of time was considered one of the more unique features of the Hörspiel and led to Schwitzke's definition "Spiel mit der verrinnenden Zeit" Das Hör. spiel, p. 244). But this theory too is predicated on the usefulness of these manipulations for communication of a semantic message. Like the "Akzidenz" theory of spatial dimension, it affords no convincing argument for the necessity of acoustical signals.

The aspects discussed so far are part of a potentially much larger role of dimension, however. When we talk of the acoustics of a certain space or the telescoping of five seconds' "erzählte Zeit" to fill thirty minutes' "Erzählzeit," we are dealing with what might be called macro-events in space and time. Macro-events fix the coordinates of characters, their movements, actions, and thoughts. They comprise the space and time frames usually identified in analysis of the role of dimension in a work of literature. Does the setting represent a real or an imagined place? Does the action occur inside or outside the protagonist's consciousness? What use is made of flashback, of memory, or prophetic leaps ahead in time? Although often used with great sophistication, these are broad, general structures, readily distinguishable from what might be called microevents. Micro-structures deal not with the sense of space and time experienced by the figures or consciousness of a work of literature, but with that experienced by the audience, whether reader, listener, or viewer. For example, the positioning of type on the printed page or the patterning of certain vowels in a text is potentially as interesting as many macro-spatial questions. Similarly, micro-time involves clearly relevant questions about the rhythm, pacing, and synchronization of poetic elements. The behavior of micro-events has been traditionally linked with performance and generally ignored in criticism for lack of objective means for its evaluation. While this neglect is serious enough for traditional literature, it can raise a complete bar to the understanding of contemporary 
forms of literature and music, and combinations of these two such as the experimental Hörspiel.

Given the monaural nature of broadcasting during the 1950s and early $1960 \mathrm{~s}$, we can understand the neglect of micro-structures in the classic Hörspiel, both in theory and in practice. In monaural transmission there is but one signal source. Consequently spatial manipulation is practically limited to the macro-structures described above. For instance, it is technically possible to transmit multiple items of information simultaneously in a monaural broadcast. If, however, both items must compete equally for the listener's attention, monaural transmission is generally unsatisfactory. The combination of simultaneously transmitted signals tends to be less than equal to its component parts. For this reason one sequence of broadcast events is always dominated by the other. As a result of the emphasis on a verbal message in the classic Hörspiel, whenever a sequence of verbal events appears simultaneously with a nonverbal sequence, that nonverbal sequence must be reduced to background noise. Since these background uses of nonverbal elements are those least cultivated in the classic era, there tends to be very little simultaneous ordering of events. A thematic noise, such as the door or the "teck tock" in Borchert's Draussen vor der Tür will appear in isolation; similarly, spoken passages, especially crucial ones, are isolated to avoid confusing their semantic messages. The exception is the fairly frequent overlapping of musical or sound effect sequences with parts of a verbal message in blending from scene to scene, but even here the blend is accomplished by bringing up the volume of the initially subservient nonverbal sequence, while fading out the verbal message.

Despite the limitations imposed by monaural transmission, some micro-durational aspects of dimension were used by directors and studio composers in working out individual realizations. An obvious example is the decision to provide brisk "city" music at a certain point, which involves filling an interval of time with more musical events than might be used in music accompanying a rural setting. As successful as the realizations usually were, their contribution to what we might conveniently call rhythmic ordering remains essentially an interpretation of the Hörspiel, not an element of its structure proper. Only when the work was conceived around these rhythms, as in fact occurred as early as 1958 in the Japanese piece Marathon (by Naoya Uchimura), would we want to consider them as part of the Hörspiel. This remarkable work is a master example 
of how thoroughly macro- and micro-dimensions of time can organize poetic expression. Its plot deals with the discovery by the marathon runner Honda during a race that his real opponent is that part of himself which would give up. Manipulation of macro-time allows flashbacks to fill out his story without interrupting the illusion of unity of lapsed time. More important, however, is the way the plot is carried by two micro-durational or rhythmic figures: the anapaest of Honda's breathing and the iambus of his footsteps. Each can be extremely effective, as in the moment when the steady rhythm of Honda's controlled breathing begins to falter, or when the clean beat of his footsteps becomes uncertain and then is momentarily obscured by the steps of a passing competitor. The rest of the sound effects and even the dialogue conform to these rhythms, producing a unified composition whose principles could be realized in many different acoustical productions, but not in a text. The Hörspiel is then neither text nor any one performance, but a range of possible performances.

Marathon demonstrated that the potential for creative use of micro-durational events as discrete elements equal to sound effects, music, and the word was present even before stereophonic broadcasting. ${ }^{22}$ Within the tradition of the German Hörspiel, however, the emergence of micro-dimension as an independent structural element coincided with and in large part depended upon the development of stereophonic transmission. To cite only the most obvious innovation, we can perceive in stereo the difference between events occurring to our left and those to our right. The initial reaction to this new potential was one of alarm. Fischer, Schwitzke, Frank, and others felt that the potential for clear differentiation of spatial dimension would interfere with, not promote, the listener's imagination. A concrete acoustical presence would, it was feared, make the absence of the visual signal once again painfully apparent and destroy the creative potential the classic Hörspiel had discovered in spatial ambiguity. As experience with stereo progressed, however, it became increasingly apparent that instead of enhancing naturalism, the almost tangible presence of stereo paradoxically enlarged the sense of aesthetic distance. What attracted the authors of the modern experimental Hörspiel to stereo was not a deepening of the illusion of reality, but the potential for manipulating concrete aspects of spatial and durational dimension. Franz Mon speaks for the majority when he says "die stereophonie ist alles andere als ein realistisches medium, sie ist ein artifizielles mittel zur ordnung 
und unterscheidung von hörwahrnehmungen, die in der monophonie ineinanderfallen müssten." 23 As we pointed out before, the communication of information rests finally upon a binary distinction-we perceive in that we perceive differences. In making possible for the first time the differentiation of signal sources, stereo has enlarged the creative potential of dimension in several ways.

The first of these is the simplest: the potential for real spatial discrimination. Although it was found unsuitable for improving the illusion of reality, this spatial potential of stereo could in fact be used to approach acoustical reality directly, without recourse to illusion. A case in point is the stereophonic organization of the sound of footsteps in the "Kerker" scene of Jandl and Mayröcker's Fünf Mann Menschen (1968). The way the various sound effects are organized stereophonically to create a closed circle brings to the work a concrete aspect of the reality of imprisonment. It is concrete, because through the shifting locus of their signals, the sound effects become icons of encirclement. The purpose is not to perfect the illusion of a cell, but to make aesthetic use of a portion of that cell's acoustical reality.

Another example of this potential occurs in Ludwig Harig's Das Fussballspiel (1966). Here the ostensible setting of a soccer match yields acoustical parallels with other formalized games of give and take: war, the hunt, Roman gladiator contests, and the celebration of Mass. As spectators to the game(s), a man and woman battle verbally over their unhappy life together. The man attempts to leave the stadium pursued by his wife and runs afoul of a cable; unable to retreat, he is caught between the cable and the crowd, and strangles. Here again, in the pursuit of the man and in his ultimate strangulation by the encircling crowd and cable, the spatial dimension makes concrete a portion of reality which a monaural realization could only render through description and/or suggestion.

Johann M. Kamps, who knows the Harig work intimately and who helped prepare the text for the original production, feels however that this use of stereo becomes illusionistic and is less advantageous than the stereophonic ordering of the parallels between war, soccer, hunt, etc.:

Die Produktion zeigte aber deutlich, dass in der Stereophonie die Eigengesetzlichkeit der Fabel das Sprachspiel stört. Die Bewegungsverläufe--der einkreisende Draht, die räumliche Verfolgung des Mannes durch die Frau, der fixierte 
Reporter-wirken bedeutungsvoll begründet im Hinblick auf die Fabel. Sie liessen trotz der sprachlichen Abstraktion weitere, vor allem optische Wahrnehmungsergänxungen vermissen. ${ }^{2 *}$

Although I disagree and feel that this spatial manipulation successfully avoids creating an illusion, Kamps's reservations point out the danger in this particular use of stereo. If the acoustical events are not sufficiently concrete to capture a listener's full attention, his imagination can easily begin to elaborate on associated visual images (which certainly accompany at least words and natural sounds), producing an unwanted illusion of reality instead of the desired concrete portion of that reality. ${ }^{25}$

A second way in which dimension functions characteristically in the modern experimental Hörspiel is in structuring sound play. Initially this suggests the sort of ping-pong trickery warned against by skeptical critics of stereo broadcasting. It may be, however, that the ping-pong effect has been too hastily condemned. Woven into a sort of acoustical game, such a left-right alteration can reward the concentration of the listener in a uniquely satisfying way. Consider the word play in the film scene of Fünf Mann Menschen. The semantic play among "k.o.," "O.K.," and "koks" is paralleled by play in the spatial dimension of the acoustical signals, as the words shift from right to left. This use of the potential for differentiation in signal position is independent of the word play and is fully contained in itself; the pattern it evolves has no special significance apart from the spatial texture it provides. The pattern is neither designed to aid an illusion of spatial naturalism, nor to further the semantic word play, but for sound play. To better sense the contribution of such stereophonic patterning to the overall effectiveness of the scene, one should play stereo scenes in both stereo and mono modes. The sound effects and / or words remain of course the same. The difference is the presence of the nonverbal element of stereophonic dimension. ${ }^{26}$

The expanded game-activity permitted by two-channel stereo is a significant characteristic of the later experimental Hörspiel. The listener to a classic work is analogous to an observer of a game in which he himself has no part. Roles are acted out before him. The monophonic experimental Hörspiel involves the listener in the game, making him a player whose internalization of the rules (or principles of organization) permits him to recognize the patterns and processes at work in the communication of aesthetic information. Stereo deepens this involvement by expanding the informa- 
tion and consequently the choices available to the listener. The addition of more signal sources, as for instance in four-channel stereo, could generate entirely new aspects to the positional play presently possible, permitting not only lateral patterns but patterns in depth as well.

The increased potential of dimension discussed so far has been spatial in nature and stems from the left-right discrimination of signal source possible in stereo. Another advantage to stereophonic broadcasting is the increased "transparency" of sounds, i.e., an enhanced ability to differentiate sounds and words. The signals have more presence and stand out more sharply regardless of position across the left-right axis. This is perhaps the main reason why stereo has been able to enrich enormously the quality of musical broadcasts and recordings. Such transparency is apparently the result of an increase in the sensation of depth present with even two-channel stereo. A limited suggestion of depth was achieved in monaural broadcasting, but was mainly perceived as a progressive weakening of volume and distinctiveness. The original production of Wolfgang Weyrauch's classic Die japanischen Fischer (1955), which tries to use the suggestion of increasing depth to indicate three levels in time, suffered from this limitation. In such cases stereo could make a significant contribution to the older pieces-a use long urged by Heinz Schwitzke and in fact now adopted by some networks. ${ }^{27}$

A third creative possibility for dimensionality proceeds in large part from this increased transparency. Whereas the classic Hörspiel, with its need to preserve semantic clarity, was bound to a sequential ordering of signals, the stereo Hörspiel uses its increased transparency to explore new ways of temporal organization. This is not a new freedom of time in the sense of macro-time. The potential in that direction was quite well developed in the classic Hörspiel (and in the novel, etc.). Rather there is now greater freedom in the dimension of micro-time to order acoustical events simultaneously. This new freedom can be used in several ways. One message can accentuate the other, or parody it. Two messages can interact to incorporate the concept of people "talking past each other," where language operates but where no connections are made. In written literature, as in the classic Hörspiel, this situation is usually suggested through sentences whose semantic contents do not respond to each other. In the "Berufsberatung" scene of Fünf Mann Menschen, note how the same situation is made concrete by the simultaneity of 
the two messages (the career counselor's suggestions and the young men's desires), and note the irony of the final isolated suggestion when the simultaneous transmission ends. The confrontation made possible by stereo does not change the two texts, each of which remains distinct and comprehensible, but creates a sort of third text of commentary on the original two.

A similarly imaginative use of this potential involves the masking of one message by another, with occasional pauses to let parts of the masked information filter through. In an important passage from the stereophonic Hörspiel version of Peter Handke's Kaspar (1968), Kaspar is being prompted to speak. He spits out single, unrelated words. On the suggestion of his prompters, he abandons these and begins to form a long, rambling phrase which masks the message of his tormentors, allowing only the two words of greatest frequency to filter through: "Worte" and "Dinge." These are key words for the entire piece, as it wrestles with the existential relationship between a thing and the naming of the thing, between a person and his self-definition through naming things, through speaking. Finally the prompters shift from "Worte und Dinge" to "Worte und Sätze," Sätze: Sätze. Sätze. The word "Sätze" penetrates Kaspar's unstructured monologue and brings him to silence; then alone he speaks his first full sentence. The cumulative effect of such masking throughout the piece is that the listener pays less attention to the individual words of Kaspar and his prompters and follows instead the syntactic models held out for Kaspar to imitate. This pattern of model-response is a structural principle of the entire piece, made especially effective at points such as the one illustrated, when Kaspar's old verbal patterns are being driven out or new ones implanted. While it is true that the masking and filtering of signals illustrated here, and even the opposition of simultaneous messages used in Fünf Mann Menschen, are possible in monaural transmission, the quality of the sound is so unsatisfactory that it seems unlikely that the creative potential for simultaneous transmission would have been tapped without the innovation of stereo.

These examples should reveal the importance of the stereophonic dimension for the modern experimental Hörspiel. As Klaus Schöning has said, the fact that practically all new experimental Hörspiele call for stereophonic realization is hardly coincidental. ${ }^{28}$ Yet it would be just as misleading for us to equate the stereo Hörspiel with the modern experimental Hörspiel as it was for the classic theorists to praise the monaural transmission of the early Hörspiel 
as its most significant characteristic (cf. Frank, p. 83; Schwitzke, Das Hörspiel, p. 241). There are modern experimental works that do not require stereo transmission and there are classic works being given new performances in stereo. What matters is the use to which the spatial and durational dimensions are put:

Die choreographische Behandlung von gekoppelten zeitlichen und räumlichen Verläufen führt zu rhythmisch-musikalisch betonten Strukturen (Choreographie ist jetzt konkret, nicht mehr metaphorisch gemeint). Schichtungen und Fächerungen von Sprache, Sprechen und Laut können einbezogen werden. Anwachsen von Einzelstimmen zu Chören, überhaupt polyphone Schallereignisse, kontrapunktische und permutationnelle Techniken, Uberlappen von Montageteilen und Anakoluthen. Die Stereophonie wird immer dort zweckmässig sein, wo sie ein komplexes Arrangement zu gliedern und damit durchsichtiger zu machen vermag.

[Kamps, p. 74]

The original apprehension of many critics that the introduction of stereo would lure the Hörspiel into a naturalism that in fact it could not support seems at this point in the brief history of stereo broadcasting to have been neutralized by the greater appeal of the nonillusionistic uses described above.

A final observation will serve to conclude this inquiry into the functions of dimension. The surprising inadequacy of stereo to improve upon the illusion created by the classic Hörspiel brings out even more clearly the extent to which these works were not acoustical art forms. While the signal was monaural and onedimensional, the apperceived world of illusion-poetic or naturalistic-was potentially quite three-dimensional. ${ }^{29}$ This difference in dimensionality helps explain, I submit, the difference in codeability which forms a central issue in this study. The classic Hörspiel, except in extraordinary pieces like Hirche's Die seltsamste Liebesgeschichte der Welt, presents a visually ordered illusion of reality. The potential for visual imaging in the Hörspiel was recognized and exploited during the classic era, but so keen was the desire to build a distinctive theory for the new medium, that the dream of pure acousticality was allowed to obscure the fact of dominant visual modality. To note this is not to discredit the works of the classic era, but to suggest that this aspect of the classic Hörspiel warrants reassessment. Moreover, this is a job for which the literary critic-armed if necessary with only the text-is well qualified.

The critic of a modern experimental Hörspiel who has no access to a performance is, by contrast, ill-equipped. For instance, since the eye is trained to read sequentially, it is difficult to imagine a 
truly adequate coding of the simultaneous acoustical events of a stereo broadcast. A printed concrete text such as Claus Bremer's "annäherung bis zur übereinstimmung" (in Bremer, Texte und Kommentare, Steinbach, 1968), that gradually disentangles superimposed words until the individual letters and finally the phrase itself emerges, uses one message to mask and filter another, but introduces specifically visual patterns not involved in the acoustical filtration. A text, in whatever form, will almost always be welcome and will serve to enrich the experience of the realization, if only by contrast. But the best text for a work that so completely involves its acoustical medium will be an adaptation that reworks the aesthetic principles involved into terms required by the medium of print. Such a text might then stand as a work in its own right, but it would still not be a substitute for the acoustical experience. Some authors and cooperative publishers make a sincere effort to provide texts that can stand independently of a performance. Some do not. One edition of a work may provide only a minimum of material and will be essentially valueless without some experience of a performance. Another edition of the same work may explore ways to give an equivalent visual rendering to the acoustical experience. ${ }^{30}$ In part, then, the success of a critic in analyzing the modern experimental Hörspiel apart from its realization will depend upon his experience with performances of like works, in part upon the sort of text provided him. The innovation of stereo is one of the key reasons why there is now such a real difference between the Hörspiel media of print and broadcast.

\section{SILENCE}

The last nonverbal element to be considered in our treatment of the Hörspiel involves a measure of paradox. In an acoustic medium, silence would seem almost a non-element. Nevertheless, the imaginative use of silence is a long-standing feature of the genre. One of the best known directors of classic Hörspiele, Fritz SchröderJahn, once defined the Hörspiel as "Pause mit Wort ringsum." 11 And, in the contemporary experimental Hörspiel, Rainer Puchert has said, "Das Wesentliche am Hörspiel sind für mich nicht die Schallvorgänge, sondern es ist die Stille" (WDR, No. 1, 1966, n. pag.). Despite these similar expressions of respect for silence, however, the ways in which this element functions in the two types of Hörspiel can be quite different. 
In the classic work, silence often functions to suggest a mood or situation of quiet, be it the quiet of tranquillity or that of suspense. Basically ambiguous, the silence is given direction by what has been called the "Musik der Stille" (Fischer, p. 152), e.g., the gentle lapping of waves, distant music, the nervous drumming of fingers, or an occasional footstep. In both instances, the accompanying sound effects merely color the truly effective element of silence.

A second function is one also frequently found outside the $H$ örspiel, especially in dramatically structured literature. It involves the evocation of the unsaid, the excitation of curiosity, and the raising or defeating of our expectations. An early example of such a dramatic silence occurs in Hans Kyser's Ankommt eine Depesche (1931).Troops supposedly loyal to the king are sent out to check the advance of Napoleon returning from exile, and as he approaches are commanded: "Feuer!" Total silence ensues, defeating the expectation raised by the command to fire on Napoleon and illuminating with superb clarity the reversal of the army's allegiance.

A third function, common only in the lyric Hörspiele of the late classic period, though not unknown in earlier works, is the use of silence to divide the flow of the action as a substitute for music or sound effects. These periods of silence are usually just the short space of time needed to indicate a change of scene and seldom exert enough influence to approach a rhythmical structuring, although there is this tendency in pieces such as Ingeborg Bachmann's Der gute Gott von Manhattan (1958).

Two of the three functions of signs are recognizable in these uses of silence. In the first and third uses we recognize primarily the sign as index, either to a mood, a change of scene, or to the organization of the poetic expression. The second, in which silence carries meaning within the context of the action, is a symbolic or thematic use (e.g., in the example from Kyser, silence indicates the change of the army's allegiance). Missing is the third class of sign, or icon. What examples of iconic uses of silence there are in the classic Hörspiel occur only in conjunction with a symbolic use of the same sign. For example, in the final moments of Borchert's Draussen vor der Tür Beckmann cries out to the two voices who had earlier urged him not to despair, his Jasager and the old man who called himself God. The silence which follows participates iconically in what it represents-the empty answer to Beckmann's tortured question, "Du sagst, ich soll leben! Wozu? Für wen? Für was?" 
At the same time, however, this iconic sign (the absence of a signal can itself be a sign) becomes symbolic of the abdication of the affirming forces in life. As an icon this sign of silence brings to Draussen vor der Tür a clear measure of acoustical necessity. Yet because the icon is invested with overwhelming symbolic significance, the sign-complex admits of verbal coding.

Pertinent to this problem of coding is the early observation that silence in the Hörspiel can be of two sorts, relative or absolute. ${ }^{32}$ Relative silence involves the absence of the dominant signal, usually verbal, but the presence of some other sound, either continuous or intermittent, which serves to remind the listener that he is experiencing a silence. The American composer John Cage has used the analogy of a Japanese stone garden, where even though it is not the stones or their relationships but the emptiness of the sand that is important, the stones are necessary to the demonstration of that emptiness. ${ }^{33}$ Such a relative silence is usually codeable. Heinrich Böll gives this instruction for the silence in his Bilanz (1958):

Stille-hin und wieder-in längeren Abständen-durch eins der Geräusche unterbrocken, wie man sie im Sommer an Sonntagnachmittagen bei offenem Fenster in ruhigen Wohnvierteln hört: Lachen, Geräusch von Kaffeegeschirr, aufschlagende Ping-Pong-Bälle, ein langsam vorüberfahrendes Auto.

[Böll, Hörspiele, p. 89]

Our eye perceives the code word "Pause" or "Stille" which suffices for the semantic level, the index or mood is established by the associated images of the "Musik der Stille," and the iconic aspect of the silence is served by the diversion of our imagination from pursuing the action while we digest this "Musik."

The other type of silence, the so-called absolute silence, is more difficult to realize acoustically and less successfully codeable. The problems of transmission clarity which restricted the use of absolute silence in the earliest Hörspiele (because of potential confusion with "dead air") were largely overcome in the classic era. Still, the use of absolute silence was generally reserved for brief transitions or moments of high suspense. During longer absolute pauses it was feared the listener would become disoriented. In a text one usually finds a minimal code word like "Pause." This presents no problem for the symbolic and index functions, which can be conveyed by the presence of a signal absent in the acoustical realization. But an 
iconic sign for silence cannot issue from such a signal. Neither does a blank space in the text, adequate for the index function of separating parts of the action, serve as an adequate sign for this function of silence, since it allows the reader to rush through a potentially important pause to arrive prematurely at the next unit of information. Coding silence where it is to function as an icon poses a dilemma: a blank space is not enough, for it fails to sufficiently distinguish the sign from the surrounding and usually irrelevant space of the page, and yet anything more is too much. A compromise solution sometimes adopted is the use of three spaced periods to indicate silence, since they do offer differentiation from irrelevant space and yet have neither semantic value nor an articulatory image. Yet because of their frequent use in printing to indicate an ellipsis (see page 60), they too are less than satisfactory. A better solution is offered by Eugen Gomringer's constellation "schweigen," 34 which seeks to convey in print the concrete reality of silence, rather than just the semantic content of its symbol:

$\begin{array}{lll}\text { schweigen } & \text { schweigen } & \text { schweigen } \\ \text { schweigen } & \text { schweigen } & \text { schweigen } \\ \text { schweigen } & & \text { schweigen } \\ \text { schweigen } & \text { schweigen } & \text { schweigen } \\ \text { schweigen } & \text { schweigen } & \text { schweigen }\end{array}$

By using the word in a visual pattern that concretizes its reality through its one-time absence, Gomringer has found one combination of stones for the garden. Unless some such visual pattern is used in a text involving an iconic use of silence, the reader can rush through the "Pause," registering the semantic meaning, but neglecting the icon.

The problems raised in this digression on coding silence were not pressing ones for the classic Hörspiel because it involved icons of silence only in conjunction with a symbolic use for the same sign. In the modern experimental Hörspiel, however, icons of silence begin to function independently of semantic meaning, and consequently the problems of coding become much more real. Of course the general de-emphasis of plot and illusion in the modern Hörspiel does not mean that the thematic use of silence disappears. Indeed, silence figures importantly in the themes of several experimental works. In Peter Handke's first work written specifically for the radio, and titled Hörspiel (1968), it functions exactly as in the traditional Hörspiel. The action progresses in form of a stylized 
interrogation. Ultimately, however, the person interrogated is able to reduce his tormentor to silence:

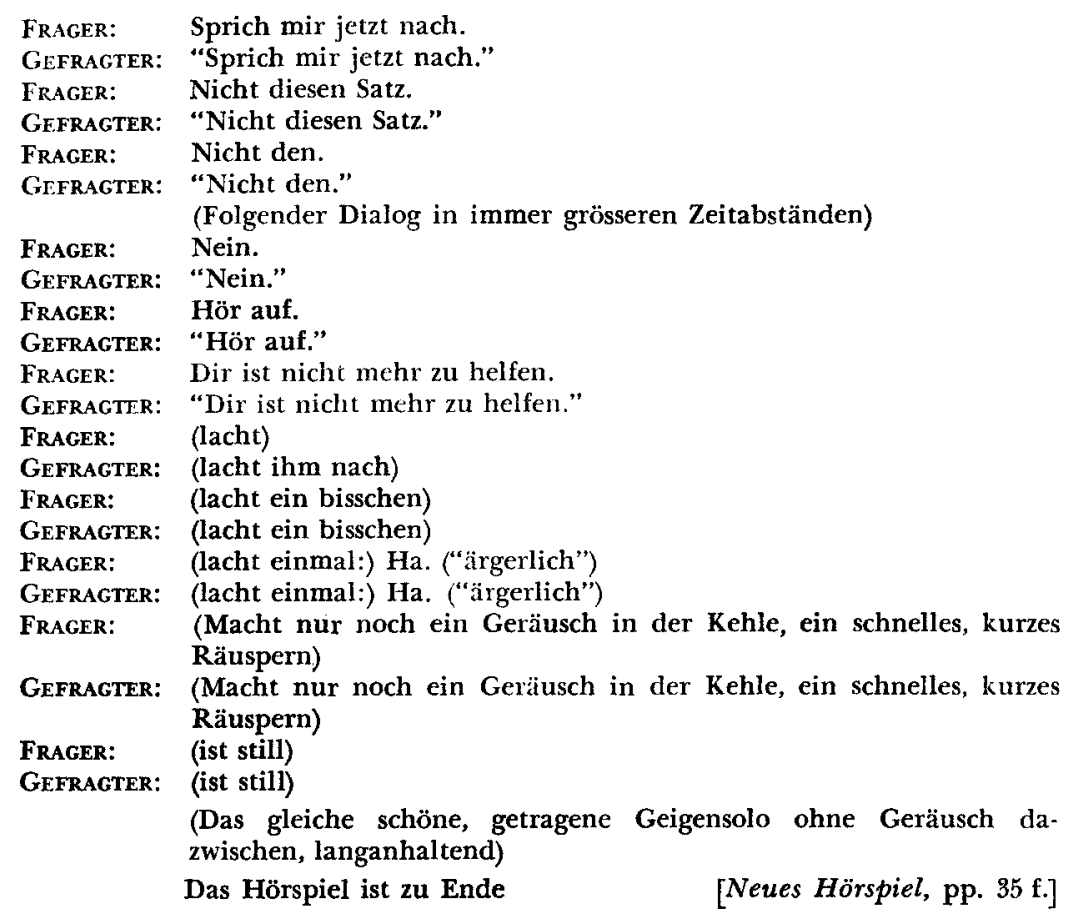

In this work the treatment of silence is more semantic than iconic and hence is adequately conveyed by the text.

Ferdinand Kriwet's One Two Two involves silence in a variety of ways, including fairly traditional combinations of icon and symbol. Yet even in combination with a thematic dimension, his icons have more autonomy than Handke's. One sequence is particularly interesting because his score modifies the traditional code for silence by addressing specifically the one determinant silence shares with sound-duration. ${ }^{35}$ The sequence, taken from a longer passage satirizing the misuse of various appeals to God, has the following notation:

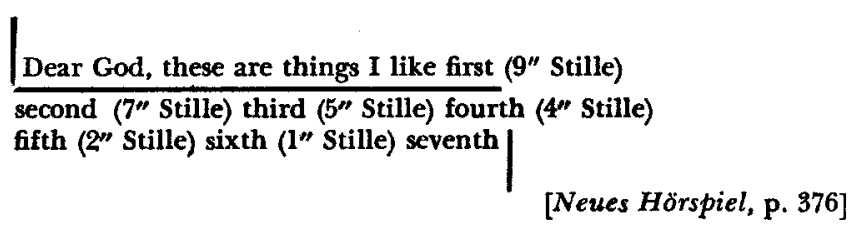


By giving the duration of the silence in seconds $\left(9^{\prime \prime}=\right.$ nine seconds $)$, Kriwet helps induce in the reader an interruption to correspond to the actual silence in the acoustical realization. The iconic function of silence in this sequence gives the musical figure of an accelerando to this clearly musical piece. Silence has other, thematic associations in this sequence, but in rendering the sequence musical it functions as an icon, as a discrete sign for itself.

Such precise specification of duration is seldom found. More frequently, silence as icon involves merely the interruption of the flow of sound. The usual graphic sign for such interruption, three spaced periods, too readily implies an intended completion, an ellipsis that the reader should be able to complete. The experimental Hörspiel, however, is not restricted to such imaginative (i.e., semantic) pauses and may intend no specific ellipsis, or even all possible completions. Silence may mean only suppression of signal and need not indicate that something (or nothing) is said. The three spaced periods in most texts give inadequate weight to the silence as silence. The following text, for example, from Peter Handke's Hörspiel Nr. 2 (1969) would seem to involve a string of elliptical addresses:

Die Maennliche Funkerstimme: (im Gesprächston, nicht ins Mikrofon sprechend, beiscite)

So was .

Ausgerechnet ...

So ein ....

Ausgesprochen ...

Und so was will ....!

(ins Mikrofon)

He! He du!

[Handke, Hörspiele, p. 31]

Expectations are of course raised by the constantly interrupted address, but it would be futile to look for the suggested completions in the fuller context of the work. Important instead is the pattern of defeated expectation. This is in fact the principle of organization for the entire Hörspiel: a model situation (conversation between taxi drivers and dispatchers) establishes certain expectations only to have these undermined at every turn. Handke conveys in this manner an incredibly dense body of aesthetic information in which silence is a fully independent sign. His use of three spaced periods was perhaps inspired by their use in the source for the spoken English portion of the work, Beckett's Eh Joe. ${ }^{36}$ There, however, 
silence serves to space out related thoughts whose semantic information is complete and obvious. In reorganizing these thoughts Handke has intentionally loosened this relationship to reduce the semantic information conveyed. Finding less sense in the verbal elements, the reader might tend to search for meaning in the nonverbal elements and could be misled by the apparent ellipsis. While the over-all pattern of defeated expectation can emerge from a textual reading, the role of silence in interrupting signals without semantic contamination is likely to be obscured.

Viewed as an interruption of signal, silence has another common iconic function in the experimental Hörspiel. Whereas the classic tradition is characterized by the widespread use of the blend technique for scene changes or shifts from one level of reality to another and from time to time, the experimental Hörspiel has thus far shown an affinity for the abrupt cut. This technique for separating scenes or events is to be distinguished from the precise splicing used by Pörtner and Kriwet, which has as its primary purpose the musical structuring of discrete elements. Rather, it involves the practice of ending an event abruptly, regardless of whether perceptible silence follows or the event is juxtaposed immediately with another (an instant of silence is almost always present). This technique was used only sparingly in the classic Hörspiel because it interfered with illusion and made the listener too aware of the technical apparatus responsible for his world of fantasy. In the experimental Hörspiel it is used precisely to avoid illusion and to ensure this awareness.

For example, Handke gives this co-textual instruction for the treatment of sound effects in his Hörspiel: "Geräusche: alle möglichen Arten von Hörspielgeräuschen, freilich jedesmal nur kurz und abrupt, nie abgerundet" (Neues Hörspiel, p. 18). The insertion of these effects into the action seems at times arbitrary and has at best only slight motivation, but this is calculated to emphasize their primary character as alienating devices. The abruptness, effected in part by the use of silence to surround the sound effects, guarantees that these effects are not integrated into the action, but remain themselves icons: ready-made Hörspielgeräusche in an ironic comment on the genre itself.

Wolf Wondratschek maintains a similar focus on the mediate aspect of the Hörspiel in his Paul, oder die Zerstörung eines Hörbeispiels (1969), in part by this same abruptness which keeps the various levels of activity ("plot," commentary on this plot, and 
metacommentary) distinct and which helps isolate each event as an autonomous unit of aesthetic information. ${ }^{37}$ He intensifies this isolation of elements by prefacing sound effects as they occur in the realization with the spoken word "Geräusch." In an introductory note he explains: "Die Zerstörung eines Hörbeispiels meint die Zerlegung eines Hörtextes in seine einzelnen Teile; dabei wird die Analyse der Illusion selbst thematisch" (Neues Hörspiel, p. 306). By breaking up the natural rhythm of illusion, silence creates the aesthetic distance necessary to this analysis.

Although this fascination with the genre as an object for selfanalysis could not be called a characteristic of the experimental Hörspiel as a whole, the focus on the process of listening, as opposed to the mere content of what is heard, is basic to the new direction of the genre. Thus when Jandl and Mayröcker insist in their co-text to Fünf Mann Menschen on scene changes without transition (e.g., "Musik bricht ab" or "jähes Abbrechen, kein Fade-out"), they suspend each scene as a distinct statement, not necessarily surrounded by silence, but set off clearly from the other scenes by the interruption of signals. Each scene acquires in this manner a singular weightiness that demands fresh attention to its acoustical events without jeopardy to the overall rhythm of the work. Silence is the neutral sign that prepares the auditory sense for fresh exposures.

A last demonstration of the use of silence as an icon focusing attention on the process of listening is made subtle because although the agent is silence, the effect is sound. That is, silencing a dominant signal can make perceptible ambient sounds which would otherwise be smothered. By ambient sounds, I do not mean those which form part of a semantic intent, such as in Böll's setting for Bilanz or the classic "Musik der Stille," but rather sounds perceived by a mind disengaged for a moment from semantic associations and freed "to enter into the act of listening, hearing each sound just as it is, not as a phenomenon more or less approximating a preconception."38 Examples of this use are few, but the principle is involved in the intermission scene of Handke's Hörspiel version of Kaspar. The verbal exchange between Kaspar and his Einsager ceases, and in this silence we hear sounds suggesting an audience in intermission, together with street noise as if auditorium doors had been opened. The principle is similar to the use by Stockhausen of what he calls "windows" in his music-spaces in which are heard excerpts from his earlier works. ${ }^{39}$ The listener is simply exposed in a different way to the process of listening by the sup- 
pression of sound (silence), which allows ambient sounds to filter through.

In summary, we see that the pattern discerned in sound effects, music, and dimension is sustained in the respective uses of silence. The innovation presented by the experimental Hörspiel lies not in thematic or index uses of these four elements, but in the use of these elements as icons. As we have found in examining the other nonverbal elements, a verbal or graphic code for an acoustical icon is very difficult to construct, although since silence is within the reader's normal repertory of acoustical experiences, a printed signal may be more successful in creating the required sign in the reader's imagination than codes for distorted sound effects, musical quotations, or dimensional play. The most important use of silence as icon relates to the characteristic demand made by the modern experimental Hörspiel that its listeners wake up to the act of listening, to the variety of acoustical events making up what Pörtner calls the new "Sprache des Hörspiels." It is this new focus, which weights periods of silence equal to periods of sound, that converts the traditional stop-and-go index function of silence into an icon in the experimental Hörspiel. Where used thus to focus attention on the act of hearing itself, the sounds of silence are poorly served by a printed text. Like sound effects, music, and dimension, silence achieves an independence from semantic meaning in the experimental Hörspiel and thereby increases the necessity for its acoustical realization. 
64 / The Emergence of an Acoustical Art Form

\section{NOTES}

1. "Natural" refers to the impression of naturalness received by the listener. In point of fact, natural sounds are not generally satisfactory when broadcast and are therefore almost always simulated in the studio. In other words, natural sounding rain may be achieved not by recording real rainfall, but by rolling dried peas back and forth over a fine-meshed wire sieve (from $B A S F$ Tape Recorder Manual, p. 52, n.d., n.p.).

2. Also the most generally esteemed, witness this typical characterization: "Günter Eich ist der deutsche Dichter, der das Hörspiel als Verwirklichung einer literarischen Kunstform auf eine einsame Höhe gebracht hat. Wollte man daran alle Hörspiele messen-es blieben sehr wenige, die daneben bestehen könnten" (Krautkrämer, pp. 90 f.).

3. The second and third dreams deviate from this pattern. See page 27 and note 4.

4. Schwitzke (Das Hörspiel, pp. $306 \mathrm{f}$.) explains that the second dream, which features no thematic sound effects at all, had been criticized as stylistically inappropriate to the other Träume, and that as a consequence Eich added the sixth dream (published separately in Neue deutsche Hefte, 1956-57, pp. 647-652), which is then usually substituted for the second in broadcasts. The third dream uses sound effects thematically, but features a cluster of related effects instead of a single sound.

5. Laughter functions both as verbal and nonverbal element, e.g., Pörtner: "Ich zähle Lachen sowohl zu den Geräuschen wie zur Sprache: es bietet einen Ubergang zwischen beiden Sphären an wie sonst nur Interjektionen oder Atemstösse." Quote from introductory material to his own Schallspielstudien entitled "Schallspiele und elektronische Verfahren im Hörspiel." This same introductory material, graciously lent me by the author, is the basis for much of the close analysis which follows. Cited as Manuscript (MS), except where portions have been published separately.

6. This "text" and the similar text cited for the first variation are reproduced here with the author's permission from unpublished material delivered as an introduction to the Schallspielstudie $I$. These passages are not intended as texts for the realization and are cited here merely to illustrate similarities between the base scene (and initial variation) and texts of traditional Hörspiele.

7. There are at this point five nonverbal elements, counting the lengthy breath drawn by the woman (Atem). Pörtner explains in his introductory materials that this effect responded unsatisfactorily to electronic manipulation and was therefore not developed in the variations.

8. Pörtner, "Schallspiel-Studien," Akzente, 16. Jg., Heft 1 (1969), p. 86. Also: "Ich unterscheide den Bereich des Schreibens vom Bereich der Akustik, weil ich in beiden Bereichen arbeite" (p. 77).

9. Speaking of the debt of the experimental Hörspiel to musique concrète in general, Pörtner says, "Musique concrète kann vorbildlich genommen werden für eine Konkretion des Hörspiels auf seine Schallgestalten" (Pörtner, "Schallspielstudien," in Essays, p. 61).

10. "Die Frage, ob das Hörspiel zur Literatur und damit zur Kunst gehöre, ist deshalb nicht zu beantworten, weil darüber, was Literatur ist, sehr verschiedene Ansichten bestehen." Peter Hirche in his acceptance speech of April 26, 1966, for the "Hörspielpreis der Kriegsblinden 1965." Quoted in the 1966 program guide (No. 2) to Hörspiel offerings published by the West German Radio (Cologne). Subsequent reference to this extremely informative biannual series (Hörspiele im Westdeutschen Rundfunk) will be given in the text as $W D R$ with the date of the pertinent issue. 
11. Donald McWhinnie, The Art of Radio (London, 1959), p. 62.

12. Rilke, Malte Laurids Brigge (Leipzig, 1927), p. 8. I am indebted to Walter Jens, Statt einer Literaturgeschichte, 5th ed. (Pfallingen, 1962), pp. 109-133, for pointing out the way this passage from Malte complements the Chandos letter.

13. Included in the Jandl collection Laut und Luise (Olten, 1966), p. 47, to which there is an accompanying record featuring the author's reading of this poem.

14. E.g., those in this list by Klaus Jungk (from "Musik im Hörspiel," Rufer und Hörer, 7. Jg., Heft 1, 1952, p. 34): "Um einige Beispiele zu nennen: Der Klang einer Violine spricht vom Inneren des Menschen, von der Seele; der eines Englisch-Horns von Schwermut; der Klang einer Klarinette von diesseitigem Glück und Leid; der des Saxophons steigert den Klangeindruck der Klarinette, man kann ihn vielleicht als charakteristisch für den von Angst und Sentimentalität bedrängten Menschen des 20. Jahrhunderts bezeichnen. Die Flöte kennzeichnet harmlose Lebensfreude, die Oboe pastorale Stimmungen; keine Gerichtsszene kommt ohne den Klang der Posaune aus, keine Naturstimmung ohne den des Horns. Charakteristische Einzelklänge oder besondere Klangzusammenstellungen, die nicht auf die normalen Orchesterbesetzungen zurückgreifen, können wesentliche Ausstrahlungen vermitteln. Wenige Takte vom Klang einer Bauernkapelle oder eines Volksliedes oder von Volksinstrumenten schaffen einen Folkloristischen Hintergrund oder die Atmosphäre einer Landschaft."

15. E.g., Frank, p. 105: “Der Baustein Musik ist eines der Elemente, das zu dieser Uberwindung des kopistischen Naturalismus im modernen Hörspiel beiträgt."

16. E.g., Schwitzke, Das Hörspiel, p. 228: "Man kann als Grundsatz sagen: es gibt im Hörspiel keine Musik ohne eine Handlungsfunktion und kein Geräusch ohne eine Sinnfunktion für den thematischen Zusammenhang." And Fischer, p. 128: "Wenn wir . . . am Primat des Wortes im Hörspiel festhalten, ... dann kann die Aufgabe der Musik im Hörspiel stets nur eine dienende sein."

17. Title of the 1970 Kölner Kurse für Neue Musik, conducted by Mauricio Kagel in cooperation with the Hörspiel department of the West German Radio. In the prospectus for the course (reproduced in part in Essays, p. 231) Kagel states, "Es wird keineswegs beabsichtigt, die Verwendung von Musik im Hörspiel zu untersuchen, mit dem Ziel, Hintergrundmusik neuerer Machart zu fördern. Im Gegenteil: die Studierenden sollen Hörspiele als Ganzes komponieren, ohne die Last auf sich nehmen zu müssen, unselbständige Handlungen zu illustrieren oder schon vorhandene dramatische Akzente nochmals zu betonen."

18. Heissenbüttel, "Horoskop des Hörspiels," in Essays, p. 28: "Die Grenze, die die Sprache mit der Musik gemeinsam hat, wird heute deutlicher, nicht als Scheidelinie, sondern als Möglichkeit vielfältiger Übergänge . . . ."

19. Quoted in Ferdinand Kriwet, "Sehtexte-Hörtexte," Essays, p. 43.

20. Quoted in Hedwig Rohde, "Hörspiel als Wortmusik oder Denkspiel," Neue Rundschau, 80. Jg., Heft 4 (1969), p. 813. The same sentiment, although with more stress placed on the musical rendering of words and sound effects than on music qua music, was expressed by Friederike Mayröcker in her acceptance speech at the receipt of the "Hörspielpreis der Kriegsblinden 1969": "Es muss akustisch befriedigen, faszinieren, reizen, d.h. der akustische Vorgang muss beim Hörer eine ganz bestimmte Reaktion hervorrufen, etwas, das in der Nähe musikalischen Genusses liegt, aber statt von Tönen von Worten und Geräuschen ausgelöst wird" (Rohde, p. 813).

21. Heinz Schwitzke summarizes the advantages thus: "Im Hörspiel können 
Personen miteinander sprechen, die sich in ganz verschiedenen Räumen, an weit getrennten Orten befinden, können Stimmen und Personen auftreten, die überhaupt keinen Ort und keine Umwelt haben, oder deren Ort und Umwelt so irrelevant sind, dass sie gar nicht erst imaginiert werden; es können an einem Ort auch mehrere Orte zugleich, und es kann eine Person zugleich an mehreren Orten sein. Alles ist denkbar, aber es ist nur deshalb denkbar, weil die Dimensionen des Raums verschwunden sind und weil das Wort und die Sprache, an keine stofflich-körperlichen Bedingungen mehr gebunden, zur Darstellung gelangen" (Das Hörspiel, pp. 252 f.).

22. It is significant that since 1962 this work has been repeatedly broadcast in Germany untranslated, and with great success. Part of this success is due to the excellent introduction by Bernhard Rübenach, but part must surely be due to the prominence of nonverbal elements like dimension.

23. Franz Mon, "Bemerkungen zur Stereophonie," in Essays, p. 126.

24. Kamps, "Beschreibung, Kritik und Chancen der Stereophonie im Hörspiel," Akzente, 16. Jg., Heft 1 (1969), pp. 75 f. Hereafter, Kamps.

25. Knilli observed two distinct styles of listening in his experiments and labeled them Nur-Hören and phantasierendes Hören. Visual imaging is more pronounced in the latter, which is most likely to be produced by plot-oriented, realistic Hörspiele, but which can also occur if a listener's attention is distracted by fatigue, extraneous noise in the room, etc. See his dissertation "Das Hörspiel in der Vorstellung des Hörers," pp. $246 \mathrm{f}$.

26. The concept of texture is meant literally, not as a figure of speech. The use of headphones rather than loudspeakers accentuates this haptic potential of positional play, though it may reduce other, more choreographic effects. As the reader of this study will already have discovered, the more modern pieces make it increasingly important to have good listening equipment. We take for granted that one ought not to read-especially a concrete text-with poor light or dirty glasses; it is often just as pointless to listen to modern acoustical art forms with inferior equipment.

27. In "Drei Thesen zum Stereo-Hörspiel," Kirche und Rundfunk, 10 July 1965, pp. 1-2.

28. Schöning, Neues Hörspiel, p. 9. Cf. this comment in a recent WDR listening guide: "Eine Sichtung der Manuskripte, die in unverminderter Fülle in den Hörspieldramaturgien eingehen, zeigt, dass ein Teil der Autoren das Hörspiel mehr und mehr als elektroakustische Aufzeichnung versteht, deren genuine Qualität es zu entwickeln gilt, d.h. sekundär als geschriebene Literatur. Dass sich diese Erkenntnis in so prononcierter Weise durchzusetzen scheint, ist sicherlich auch der Stereophonie zuzuschrieben, die in wachsendem Masse nicht nur die Realisation, sondern auch die Dramaturgie der Stücke determiniert" (WDR, No. 2,1969 , p. 4).

29. First noted by Knilli, "Das Hörspiel in der Vorstellung des Hörers," p. 83

30. For example, compare the minimal text of Harig's Das Fussballspiel by Limes (in the collection Ein Blumenstück, Wiesbaden, 1969) with the elaborate score by edition hansjörg mayer (Stuttgart, 1967).

31. Quoted in WDR, No. I (1967), p. 85, and in Schwitzke, Das Hörspiel, p. 122. Schwitzke, especially, discusses Schröder-Jahn's fascination with silence. See p. 324.

32. Fischer, p. 152. The sense of "absolute" is not to be taken strictly, of course, as experiments in anechoic chambers indicate there may be no such thing as absolute silence to the human ear. See John Cage, Silence (Cambridge, Mass., 1961), p. 8. What is meant is then merely the absence of any acoustical signal.

33. John Cage, Silence, p. 70. Silence is many things to Cage, and certainly 
not all of his remarks apply to the sense with which I use the term here. Nevertheless, because of the growing similarity between the Hörspiel and the sort of contemporary music Cage helped pioneer, many of his insights are illuminating for our purposes.

34. Gomringer, worte sind schatten (Reinbek bei Hamburg, 1969), p. 27.

35. Cage, Silence, p. 18.

36. A television play published in the collection Cascando and other Short Dramatic Pieces (New York, n.d.).

37. I am indebted here to Schöning, Neues Hörspiel, p. 11.

38. Cage, Silence, p. 23.

39. Karlheinz Stockhausen, notes to the recording of the composer's Mikrophonie II (CBS: stereo 3211 0044). 


\section{Verbal Elements}

OUr concern with nonverbal elements has not precluded consideration of verbal material. In fact, some of the passages used to demonstrate the function of nonverbal elements have obviously displayed considerable language material. It is now time, however, to focus on this latter aspect of the Hörspiel and explore the relationship of the processes thus far observed to what is traditionally the heart of poetic expression, its language.

A maximum of production necessity has already been recorded by the nonverbal elements. At that uncertain point where the boundary between language and music becomes totally fluid, the necessity of an acoustical realization is obvious. The reverse is not true, however. The mere absence of nonverbal elements does not necessarily mean that a Hörspiel drops to the bottom of the scale. Nor does it mean that experimentation is eliminated. There are, as we shall see, highly experimental Hörspiele which feature almost exclusively verbal elements and yet manifest a high degree of production necessity.

The function of language in the classic Hörspiel reflected the overwhelming concern of these works with the poetic communication of a semantic message. "Poetic" in this sense means simply that the semantic information of the message was delivered in some way significantly different from the way in which this same information might be delivered in a radio essay, whether because it was cast in an extended metaphor, expressed in rhetorical tropes, dramatized or merely fictionalized. This poetic communication was characteristically, indeed almost uniformly, formed as a plot with discrete figures, or at least voices, acting out roles. Schwitzke (Das Hörspiel, p. 194) maintains correctly that these two layers, message and plot, were in fact so closely interwoven that it is impossible to distinguish them. And Krautkrämer would characterize the basic poetic goal of the traditional Hörspiel as "Handlungen darzustellen" (Krautkrämer, p. 120). As the latter saw in 1962, an unfor- 
tunate consequence of this almost exclusive concern for the communication of the plot and its attendant themes was a corresponding neglect of language. Such neglect was certainly never total. Experiments like Orson Welles's famous production of The Invasion from Mars $^{1}$ demonstrated that something approaching total illusion is possible in a radio broadcast, but authors and critics recognized that the special sort of vision a poetic statement brings to our experience is dulled unless at least a secondary awareness of the medium is preserved. Gerald Bruns's remark that the language of poetry "seeks to preserve itself against annihilation by its content"2 is applicable as well to the Hörspiel, and writers in the new genre soon realized that even for realistic works the everyday referential bond between sign and content had to be loosened.

Still, the primary function of language in the classic Hörspiel was the symbolic coding of semantic meaning. Just as nonverbal elements have been subjugated to the semantic message in the classic era, so can verbal elements be thus subjugated. Language was sufficiently stylized to maintain a secondary focus on the medium of expression, but it seldom transcended such a mediate role to become pure verbal material in poetic combination. Instead of the medium of radio, the classic Hörspiel used the medium of language.

For this reason adaptations of classic Hörspiele to other literary genres are often very successful. Friedrich Dürrenmatt's Die Panne, Max Frisch's Herr Biedermann und die Brandstifter, Borchert's Draussen vor der Tür, all originally presented as Hörspiele, have been successful on the stage, in television, or as short stories; they remain essentially literature and lend themselves well to a reading in all their forms. Other works involve language as subject as well as medium, and thus seem perhaps more appropriate as $H \ddot{o} r$ spiele, without in fact achieving production necessity. The plots of both Wolfgang Hildesheimer's Herrn Walsers Raben (1960) and Siegfried Lenz's Das Labyrinth (1967) deal with the ability of the protagonist to make people disappear, in the former work by a magic incantation that converts burdensome relatives into ravens, in the latter by a garden labyrinth that permanently "loses" guests. Because the thematic agent in one play is a verbal incantation and in the other a visual maze, the Hildesheimer piece possesses a certain appropriateness to the medium of radio, an appropriateness absent in Das Labyrinth. Aside from this twist, however, the language of Herrn Walsers Raben is still highly referential and essentially 
passive. The thematic involvement of language makes the play effective as a Hörspiel, but does not exclude a silent reading as a fully adequate realization of the text.

A work rises in the scale of acoustical necessity only when the actual acoustical aspect of language is activated. This happens when the phonetic reservoir of the verbal material is tapped, that is, when it begins to matter not only what is said and how, but with what sounds. A passage from the opening narration of Günter Eich's Das Jahr Lazertis (1954) provides an example of this sort of activation:

Ich sprang aus dem Bett und stürzte ans Fenster. Ein Paar ging in der Richtung zur Wilhelmstrasse. Beide trugen schwarze Mäntel, der Mann einen Zylinder, die Frau, die fast ebenso gross war, ein zierliches Hütchen. Es kam mir vor, als schwankten sie beide. Lachten sie auch? Ich rief, aber sie drehten sich nicht um und bogen links in die Fischergasse ein. Hastig zog ich mich an und rannte auf die Strasse, in der Hoffnung, sie einzuholen.

In grossen Flocken fiel Schnee auf ihre Spuren, die ich bald verlor. Ich hatte den Stein der Weisen besessen, so lange, wie ein Blitz währt. Findet man ihn zum zweiten Mal, wenn schon beim ersten alles Suchen vergeblich ist? Der Zufall war meine beste Hoffnung. [13 eur. Hörspiele, pp. 153-154]

Alliterative repetition such as in Flocken / fiel, hastig / Hoffnung / einzuholen, Schnee / Spuren; assonance as in Stein / Weisen, Such$e n / Z u f a l l$; and the overall prominence of $/ s /$ and $/ t s /$ in this passage are indications of the most basic level of activation of the sound structure of language. On another level the direct link with experience that onomatopoetic words afford, in contrast to prosaic denotation," is exploited in phrases such as "das Schillern einer Schlangenhaut" (p. 153). To note such activation is not to draw conclusions about sound-symbolism in the work. (This aspect would be interesting to examine, but would have to be analyzed in the light of a phonemic analysis exceeding the scope of our study.) We simply take cognizance of the fact that Eich involves poetic euphony as a device for the selection and organization of his verbal material.

The central structural feature of the work is also phonetically determined Eich erects a paronomastic chain of words consisting of Lazertis, Laporte, Lazerten, Laertes, Lazarus, la certitude, and La Certosa, each of which takes the protagonist a step further in his search for "das Wort, das alle Geheimnisse löste" (p. 153). The narrator and protagonist Paul is roused from his sleep by this Word, which he believes sounds like "Lazertis," a word initially without meaning for him except for the promise it contains. His search to 
recapture the exact word leads him to the hunchback Laporte, who engages Paul to paint lizards (Latin lacerta) on a jungle expedition. Together they join a doctor who calls himself Laertes and who, after Paul has nursed a sailor stricken with leprosy (who likens himself to the Biblical Lazarus), diagnoses leprosy in Paul, giving him la certitude and assigning him to the leper colony $\mathrm{La}$ Certosa. The plot is thus almost totally motivated by Paul's encounters with these words. Each encounter leads him to fathom the meaning of the word which sounds like the one word he seeks to recapture. Ultimately he sees that the meaning of each lay in his being passed to the next, as the chain of words leads him to his destiny: recognition of the claim to his brotherhood and love of even the remotest outcasts on earth. By extension, the Hörspiel deals also with the fate of the poet, whose destiny it ever is to search for "das Wort, das alle Geheimnisse löste." On both levels the semantically organized plot is carried by verbal sound play, just as the plot in Eich's Sixth Dream was motivated by nonverbal sound effects.

For the latter work it was argued that despite its undisputed effectiveness when broadcast, its message and acoustical effects were still basically accessible to a reader of the text; signals for the sound effects involved were not necessary to a performance of the work. When the acoustical effects stem from verbal material in the first place, a Hörspiel will continue to demonstrate acoustical, rather than production, necessity as long as the reader's voice is a sufficient instrument for its realization. The phonetic involvement in Das Jahr Lazertis requires articulation of verbal material, but the receiver of Eich's communication can himself provide this articulation; he need not receive actual verbal signals. The lament of the poet and critic Yvor Winters, that "the readers are numerous who hear nothing when they read silently and who are helpless in their efforts to read aloud" 4 is doubtless a true estimation of the problem of insensitivity that every poet faces, but I suspect it is equally true that the listeners are numerous who hear nothing but the semantic level of a Hörspiel and who are deaf to the acoustical phenomena that give the genre its unique promise. In each case the perception of these phenomena is not at issue, only the success or failure of the poet to register his effects in the apperception of the reader or listener. The fact that he will fail for regrettably large numbers of people would be a poor basis on which to stop writing poetry. And it is an equally poor basis on which to argue that all Hörspiele or poetry must be performed. The dogma that "gelesene 
Hörspiele in keinem Fall auch nur annähernd jenen Eindruck vermitteln, den die Umsetzung in akustische Plastizität bei der fertig produzierten Sendung hervorruft . . .," shows perhaps too great a love for the Hörspiel and too little appreciation for the capacity of a poet like Eich to excite, through no other medium than his language, the full imagination of his reader. The eloquent praise paid the magic which supposedly adheres to the spoken, as opposed to the written, word ignores too much the level of articulation present in even a silent reading.

Adding to the confusion surrounding the myth of the spoken word is the traditional designation of some mature classic works as lyric Hörspiele. The lyricism of many of these is beyond dispute, but sometimes this lyricism was offered as evidence that the resort to optical illusion was overcome in the Hörspiel, with the implication that in its place came an increase in acoustical imaging and production necessity. It is true that plot receded as a structuring principle of the lyric Hörspiel, parts were spoken less by plastic figures than by voices, and the level of reality on which the work functioned became internalized. The strict demands of prosaic causality were loosened, the contours of illusion blurred, and metaphoric tropes began increasingly to replace simple denotation. Together with the actualization of the phonetic level of language demonstrated above in the discussion of Eich's Lazertis, these characteristics fully merit the designation lyric. They do not, however, demonstrate so much production necessity that a reading experience is excluded; in fact the lyric Hörspiel admits of a reading exactly as well, and demands from a reading exactly as much, as a lyric poem.

A widely cited example of a lyric Hörspiel is Ingeborg Bachmann's Der gute Gott von Manhattan (1958). A story line is still present and traces the development of love from the casual encounter of two young people. The illusion of reality is toned down by several devices which couch the basic dramatization in a decided lyricism. The basic story of Jennifer and Jan is related by the Good God of Manhattan, on trial for the assassination of Jennifer, and becomes thus internalized as his confession of, and justification for, his paradoxical act. The real plot centers around the resolution of this apparent paradox: that it should be the goal of a good god to reward love by assassination of the lovers. Episodes from these two levels, the lovers' progress towards a purer love and the Good God's defense before a mysterious judge, alternate with each other and with scenes featuring the squirrels Frankie and Billy, envoys 
of the Good God. An illusionistic progression of scenes is further relaxed by the addition of collage-like cadances composed of advertising imperatives, traffic warnings, and admonitions loosely tied to the theme complex of god-love-death:

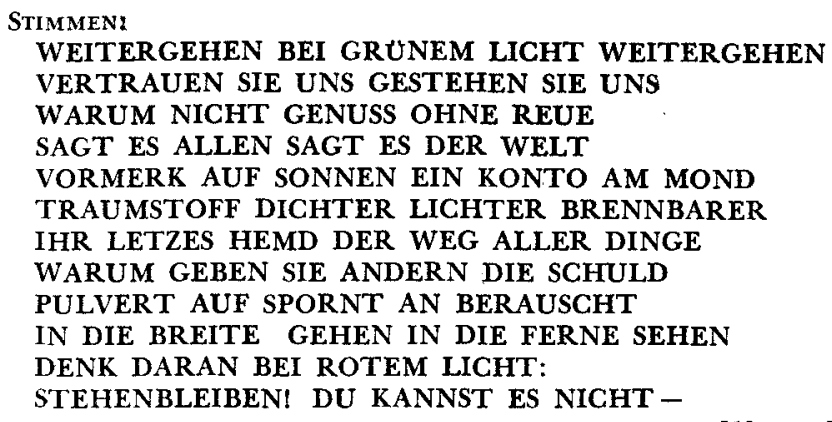

[13 eur. Hörspiele, p. 219]

The connection between these cadences or their component elements and the action remains one of association only, never of causality. The purpose is more to keep the flow of action loose, to keep the levels from congealing into a smooth mimetic story, than to knit parts together. The same looseness is present in many of the exchanges between principals as well, where it functions to minimize the causal responsiveness usually associated with dialogue. Bachmann can thus exploit individual, internal lyricism without sacrificing the structural advantages of dialogue:

Auf der Strasse

JAN: laut, dann lauter und zuletzt in Verzweifiung Jennifer! - Jenniferl - Jennifer!

Zeitungsverkaeufer: Treffen der Veteranen - Treffen der Hammel - Treffen der alten Trommler.

JAN: sich an den Ausrufer wendend Sie muss hier vorbeigekommen sein, mit einem Koffer. In Rosa und Weiss, mit Locken, die über die Ohren fallen. Und diesem Blick: wie gefällt Ihnen?

Zeitungsverkaeufer: Gesehen. Nichts hat man gesehen. Rosa und Weiss? So sind sie alle, mir ist das auch einmal passiert. Die sehn Sie nicht wieder. Aber fragen Sie einmal den dort von der Polizei. Jal Den mit dem Helm auf dem Kopf und dem Knüppel in der Hand.

JAN: auf den Polizisten zutretend Weit kann sie nicht sein. Sieht aus wie alle und ist es doch.

PoLIzısT: Sind Sie ein Angehöriger?

JAN: Ich habe gleich angefangen zu laufen, als ich merkte, dass es anders kam. Hundert Meter Vorsprung hatte sie.

Pouzzist: Ach was, Vorsprung. Sie sind ein sehr netter Mensch, aber ich muss zuerst die Kinder da über die Strasse führen. Dann reden wir weiter. Nicht wahr, Kinder? 
KINDER: Bring uns! Trag uns! Komm, Hampelmann! Komm, feiner, alter Polizeionkel.

JAN: weitergehend, laut und weithin Jennifer! Jennifer!

[13 eur. Hörspiele, pp. 229-230]

In both passages quoted above the activation of the phonetic level of language is obvious. Assonance and alliteration are present, many lines feature patterns of phonemic and / or lexical repetition, and the rhythm of such passages is emphasized through contrast with natural, everyday dialogue:

JENNIFER: Geben Sie mir die Kleider. Sie dürfen sie anrühren. Sie müssen sich auch nicht abwenden. kalt An welche neue Höflichkeit und Distanz wollen Sie mich gewöhnen?

JAN: Es tut mir leid.

JFNNIFER: Obwohl ich so reizend gewesen bin?

JAN: mit Wärme Verzeih, bitte. Ich hätte es wissen müssen.

Es wird an die Tür geklopft.

Frav: von draussen Räumen Sie das Zimmer oder bleiben Sie?

[13 eur. Hörspiele, p. 219]

To the fragile connection between plot episodes on the two levels and the alternation between prosaic and lyric diction comes the blurring of images, especially in those passages characterized by stronger lyricism. The scene quoted above in which Jan runs after Jennifer in the streets of Manhattan is typical of this blurring. There can be no serious question about the presence of visual imagery, but as soon as the image begins to take shape, it is blurred by the refusal of the dialogue partner to incorporate the image in his response, or by the switch to another, unrelated image. Images form and dissolve continuously, giving an impressionistic view of the streets and people of Manhattan without firm contours, yet as filled with color and shape as with sound:

JENNIFER: Langsam Küss mich. Auch auf der Strasse. Auch vor dem Fenster mit den Orangen und brauner Ananas. Auch vor dem Kreuz des Rettungswagens und dem Dromedar, das der Zirkusmann hier vorüberführt. Auch vor den Kernen, die geflogen kommen von Pfirsich und grüner Dattel, und die die Mulatten wegwerfen.

[13 eur. Horspiele, p. 231]

In fact, despite the lyricism present and the role of the phonetic level of language in this lyricism, visual or object imagery is of undiminished importance in this work. The position taken by the classic theorists, "dass für die Beurteilung des Rundfunks in aesthetischer Hinsicht nicht die sichtbare Welt, sondern die Wortkunst 
Ausgangsspunkt ist" (Fischer, p. 33), chooses to ignore the fact that even in thoroughly lyrical Hörspiele such as Der gute Gott the dominant modality of imagery is visual. To ignore this visual imagery in Der gute Gott is particularly dangerous, as both the action of Jan and Jennifer's story and the solution to the riddle of the Good God's action are presented in visual terms. As their love becomes purer, Jan and Jennifer seek different hotel rooms, ascending from the squalor of their first room below street level to the rarefied atmosphere of the fifty-seventh floor. At this point there is no higher room for them. Their love has reached the limit of human containment. Jan says, "Ich bin mit dir und gegen alles. Die Gegenzeit beginnt." The Good God explains that this is the sign of a new order and that he was forced to act:

GUTER GorT: Ja, auffiegen müssen sie, spurlos, denn nichts und niemand darf ihnen zu nah kommen. Sie sind wie die seltenen Elemente, die da und dort gefunden werden, jene Wahnsinnsstoffe, mit Strahl- und Brandkraft, die alles zersetzen und die Welt in Frage stellen. Noch die Erinnerung, die von ihnen bleibt, verseucht die Orte, die sit berührt haben. [13 eur. Hörspiele, p. 245]

"Auffliegen" has of course a double meaning, for it connotes a continuation of their ascent from the base of Manhattan, while denoting the assassination by bombing. Jan and Jennifer represent other great lovers whose happiness would not be tolerated on earth: Orpheus and Eurydice, Tristan and Isolde, Romeo and Juliet, Abelard and Heloise, Francesca and Paolo. "Zur Hölle mit ihnen" cry the envoys Frankie and Billy, invoking an ironically inverted spatial image: if "heaven" is found on earth (Manhattan is the Indian word for "himmlische Erde"), then "hell," understood as that point at farthest remove from heaven, is a positive destination. The actual assassination releases only Jennifer, because at the last moment Jan sinks back into the earthly world of everyday events. He leaves their hotel room on the fifty-seventh floor to turn in his return ticket to Europe, but instead of rushing back to Jennifer as promised, he pauses in a bar on the street level and begins to read a newspaper. He has not met the test, and is not with Jennifer when the bomb planted by the Good God goes off. "Er war gerettet. Die Erde hatte ihn wieder" (13 eur. Hörspiele, p. 248).

Thus the visual images and patterns in this piece are very rich and very important to the communication of its message. The semantic shape of the work is not acoustical, but optical, depending upon object images evoked through words-images softened to be 


\section{6 / The Emergence of an Acoustical Art Form}

sure by the euphony and rhythm of the verbal stimuli, but no less visible for those soft contours. There is nothing inconsistent in a lyrical Hörspiel whose dominant modality of image is visual. And nothing inconsistent in expecting such a Hörspiel to be equally rewarding to reader and listener.

When the acoustical level of language becomes more important than it is in the pieces by Eich and Bachmann, the classic Hörspiel is already in transition. An example of this transition is Ilse Aichinger's Besuch im Pfarrhaus (1962), in which the semantic level of language is so reduced that verbal imagery (i.e., words generating images of other words) participates almost equally with visual imagery (i.e., words generating object images). The semantic content of the Hörspiel involves a pair of children relating the activities of the day to their pastor. Into this open framework is packed a series of anecdotes with the potential for visual imagery which is often left so undeveloped that only images of the surface level of language persist. The first anecdote seems about to describe the children's activity around the pastor's house:

Pearrer: Und in sehr vielen Pfarrhäusern ist es seit langem üblich, abends zu erzählen. Darum erzählt, ihr Kinder, was habt ihr getan?

1. KIND: Von Früh an?

2. KIND: Weisst du's noch?

1. KIND: Wir standen auf und schlichen rasch hinunter.

2. KIND: Auf Socken. Und schlüpften in die Schuhe erst im Garten.

1. KIND: Und pflanzten dem Pfarrer eine Hecke ums Haus.

Pfarrer: überrascht Mir? Ach ja, ich erinnere mich. Aber das war sehr früh.

1. KIND: ohne sich beirren zu lassen Da trat der Pfarrer heraus.

Vögel, Geräusche des Morgens im Garten

Pfarrer: Was wollt ihr, Kinder, und so früh am Morgen?

1. KinD: Wir haben Ihnen ein Halsband ums Haus gelegt.

PFarRer: Lacht Das soll mir wohl die Bienenstöcke vor den Wölfen schützen? 1. KIND: Das soll's!

Pfarrer: Aber ein schöner Morgen, wie Wasser. Ich habe mir heute meine Kanone schon hell gerieben.

2. KIND: lebhaft Das Mündungsfeuer!

Pfarrer: Wollt ihr Kaffee?

1. KIND: Wir sollten auch noch zur Frau Bootsverleiherin.

Pfarrer: Aber auf eine Tasse?

I. KIND: Auf eine Tasse, ja.

PFARrer: Kommt jetzt herein

Das Scharren der Schuhe auf dem Eisen vor der Tür.

[13 eur. Hörspiele, pp. 189-190]

The potential object imagery of "Hecke ums Haus" is blurred by the focus on the verbal material brought by the parallel alliterative 
structure of the subsequent "Halsband ums Haus." Other images defy visualization because of internal contradiction ("schwarze Sonne") but remain as verbal impressions on the mind's ear. There is in these anecdotes and half-images the constant suggestion of a referential level outside that denoted by the language itself, but the absence of such a base for metaphor or symbolic connection is what gives this work its uniqueness. The bond between verbal sign and referent is weakened through the refusal of the language to "make sense." Because the referent seldom matures into a full visual image, reader and listener alike are continuously referred back to the sign, to the surface level of language where euphony, repetition, and rhythm work out their patterns of verbal imagery.

The process under way in Aichinger's Besuch im Pfarrhaus is still being developed in the contemporary experimental Hörspiel. Where the mediate function of language persists, the information conveyed has increasingly to do with language itself, rather than with an extra-linguistic situation outside the realm of verbal behavior. The language of the Hörspiel becomes in such instances a metalanguage. Where language ceases to play a mediate role altogether it can further weaken the bond between its material self as sign and its semantic referent until this material character emerges not as vehicle for a meaning but as agent in poetic combination.

Using a structure similar to the base-scene and variations of his Schallspielstudie I, Paul Pörtner takes verbal material from his translation of Un Coup de Dés jamais n'abolira le Hasard by Mallarmé through several stages in his Alea (1970), gradually abstracting the semantic information initially present, condensing the verbal material until the words bear a maximum semantic load, and then shattering this mediate function of language by exploding the words themselves into their component sounds. Pörtner's goal is "mittels Schall den Gehörsinn zu mobilisieren. . . ." His starting point is the dual nature of language-medium of semantic information about the extra-linguistic world, and material sign (in this case, sound). Gradually, however, the semantic context in Mallarmé's poem (shipwreck as a metaphor for the triumph of chance over the power of the human will) is condensed and altered electronically through a process of permutation, impeding the tendency for assignment of semantic meaning and exposing more and more the innovative aspects of aesthetic information. The distribution of information shifts so far that ultimately even the basic context necessary 
to perceive innovation is threatened. The final variation exceeds the point at which verbal material exercises a denotative function (first variation); it exceeds the point at which connotation and verbal association are densest (second variation); it reaches the point at which apperception (understood as the process of integrating perceived signals meaningfully) is suspended and the listener is exposed to the process of pure perception. What is perceived is the same verbal material of the first variation, now reduced to its pre-lexical components, modified electronically and through the imposition of unarticulated vocalizations (cry-rhythms, etc.), and distributed over the left-right axis of stereophonic dimensionality. The verbal material which in the classic Hörspiel is used almost exclusively as a medium for extra-linguistic expression is here fully exploited in its other capacity as sound. As Pörtner says, "Wechsel der Perspektiven: Phonetologie statt Poetologie" (WDR, No. 1, 1969 , p. 3).

A Hörspiel that uses language mediately, but not for the communication of exclusively semantic information, is the Monolog der Terry Jo by Bense and Harig. As was described in the introductory chapter (page 6), the verbal material of this piece is of two types: the normal, prosaic comments of persons attending the unconscious Terry Jo, and her monologue. The monologue, initially rendered synthetically by a Vocoder to suggest her "unconsciousness" and composed of meaningless combinations of sounds, gradually becomes articulated speech. Between the random grouping of sounds, or zero-order approximation of language, and the point where sufficient context has been established to permit the communication of semantic meaning, the information conveyed is largely statistical, aesthetic information. The first time a recognizable lexical word is articulated by the Vocoder it conveys, to be sure, the semantic fact of returning consciousness, but also considerable aesthetic information by virtue of its low probability of selection.

Of course Monolog der Terry Jo involves more than the mathematical approximation of language. As brought out in the earlier discussion of this work, its theme raises broader questions of human verbal behavior. The interaction of aesthetic and semantic information is related to human experience to no lesser degree than are the themes of the traditional Hörspiel. But where language in the classic era merely mediates some aspect of extra-linguistic experience, or at the most attempts a metaphoric facsimile, the language 
of a work like Terry Jo actually participates in one of the very basic aspects of human experience. The contribution of this sort of experimental literature is its demonstration of a fact known by linguists and psychologists for some time, but too often neglected in traditional literature, the fact that the transfer of meaning is only one of several aspects of verbal behavior. ${ }^{7}$

The thematic use of language as human verbal behavior is the core of so many experimental Hörspiele that it forms a characteristic of parallel importance to the reduced semanticism already described. Since language as both medium and theme was mentioned in connection with Günter Eich's Das Jahr Lazertis, it merits pointing out that in the contemporary experimental Hörspiel verbal material is thematic in quite a different sense from Eich's metaphorical notion of the Word, "das alle Geheimnisse löste." Peter Handke says of his "Sprechstücke":

Die Sprechstücke sind Schauspiele ohne Bilder, insofern, als sie kein Bild von der Welt geben. Sie zeigen auf der Welt nicht in der Form von Bildern, sondern in der Form von Worten, und die Worte der Sprechstücke zeigen nicht auf die Welt als etwas ausserhalb der Worte Liegendes, sondern auf die Welt in den Worten selber. 8

A Sprechstück like Weissagung (written in 1966 and although not originally conceived as a Hörspiel, broadcast repeatedly in Hörspiel programming since) abounds in visual images, in fact consists of little but common images that have become figures of everyday speech. Simile follows simile, page after page or minute by minute, with only slight variation in pattern $(A, B, C$, and $D$ refer to the four voices used) :

A: Die Fliegen werden sterben wie die Fliegen.

B: Die läufigen Hunde werden schnüffeln wie läufige Hunde.

C: Das Schwein am Spiess wird schreien wie am Spiess.

D: Der Stier wird brüllen wie ein Stier.

A: Die Statuen werden stehen wie Statuen.

B: Die Hühner werden laufen wie die Hühner.

[Sprechstücke, p. 53]

The repetitive structure of the material quickly dulls the attention for imagery and focuses instead on the grammatical pattern that creates a grammatically self-fulfilling prophecy by using the object of a simile as the subject of its own prophecy. The result is a tautology, a meaningless prophesy that emphasizes the emptiness of everyday speech built on such clichés. Although his technique 
seems innocent, in that he simply lists extant figures of speech, Handke's critical position emerges very clearly. Ernst Wendt, writing in Theater Heute, has characterized the deceptive harmlessness of Handke's style, which manages to condemn without the heat of accusation: "Keine Argumentation, keine Diskussion mit der Gesellschaft sondern Reduktion dieser Gesellschaft auf ihre Sprachstrukturen, ihre Verhaltensstrukturen" (quoted in WDR, No. 2, 1968, p. 22). Although Handke minimizes any social "engagement" in his work $^{9}$ and insists that he is interested only in language, the intimate connection between language and the totality of human behavior makes the drawing of certain critical conclusions inevitable. The succession of clichés finds a telling culmination in the final, most paralyzing prophecy of all: "Jeder Tag wird ein Tag sein wie jeder andere." This final line relies on the creation of sufficient resistance in the audience to the way language can govern behavior to convey the implication that it need not always be so. The world reflected in the language we use is in part also created by that language.

In his larger pieces, the Hörspiel version of Kaspar, Hörspiel and Hörspiel Nr. 2, Handke takes the conscious risk of investing what are essentially very much still Sprechstücke with a recognizable action. The resort to an extra-linguistic situation is dangerous because it tempts one to view Handke's language in a traditional sense, as symbol or medium for extra-linguistic meaning, as if $H \ddot{H} r-$ spiel were a reflection on an interrogation within a police state or Kaspar a work about Kaspar Hauser, or Hörspiel Nr. 2 a work offering insight into the world of taxi drivers in large metropolitan cities. Handke counters this tendency through a variety of alienating devices, ranging from the title ("Hörspiel") to the distortion of voices and mechanical use of unmotivated sound effects. It is the tension between the narrow focus on language as a model of human behavior and the listener's desire to know more about the extralinguistic situation which saves these overly long works from becoming boring.

The situation in Hörspiel is an interview between a solicitous figure (Frager) and the victim of an earlier interrogation (Gefragter). The techniques of that interrogation are the subject of the current dialogue, which is a dialogue in appearance only. Actually the questions of the Frager are not answered by the Gefragter, whose comments are answers to unasked questions:

FRAGER: Sprechen Sie auch manchmal mit sich selber? 
Gefragter: Ja, es ist mir lästig, andere gierig an ihrer Zigarette saugen zu hören, wenn sie verzweifelt sind.

Frager: Und schämen Sie sich, wenn Sie sich dabei ertappen, dass Sie mit sich selber gesprochen haben?

GeFragter: Nein, es ist nicht weiche Butter gewesen, sondern eine dicke Zeitung, die aus dem letzten Stockwerk auf die Strasse geklatscht ist.

Frager: Und schauen Sie dann herum, ob jemand oder, besser gesagt, ob wohl niemand Ihnen zugehört hat?

Gefragter: Ja, ich habe vom Nagelfeilen Herzklopfen bekommen.

Frager: Und fangen Sie dann aus Scham zu summen oder zu pfeifen an?

Gefragrer: Nein, ich habe keine Impfnarbe am Oberarm.

[Neues Hörspiel, p. 24]

Establishment of the contact missing here is the goal of the linguistic process depicted in the work. The interviewer exhausts the full repertory of interrogative rhetorical devices, moving back and forth from solicitude to insults and subtle threats, to bribery and flattery. Handke plays with the notion of contact, withholding semantic contact despite the arsenal of questions, but tossing in the sort of quasi-contact featured above on the syntactic level or this sort of momentary contact on the lexical level: "Frager: War es nicht angenehm, wenigstens einen Finger bewegen zu können?/ GEFRAGTER: Sie haben mit den Fingern geübt, bevor sie zugegriffen haben" (Neues Hörspiel, p. 19). Only after the work is more than half finished does the dialogue solidify into a real exchange, but even that occurs in one of the "flashback" scenes to the previous interrogation. Contact between interviewer and victim is delayed still longer, and once established is permitted to develop only so far, never to the point of an actual exchange of information in the everyday sense. At one point the stereophonic differentiation is used to permit responsive contact but simultaneously deny informative exchange through the blanketing effect of this very contact:

FraGER: Wie hat der Fliegenfänger (Sie lachen)

FrAGER: Entschuldigung.

(Sie lachen)

Frager: Was wolltest du denn(Sie lachen)
Gefragter: Die Pistolenkugel ist an der Spitze-

GeFragter: Entschuldigen Sie.

GeFragter: Was haben Sie mir denn-

[Neues Hörspiel, p. 32]

At another point the contact serves only to keep channels of communication open:

Ausfrager C: Sind Sie der glückliche Besitzer dieses Apfels? AUSGEFRAGTER: Ob wer was ist? 
Ausfrager C: Ob Sie der glückliche Besitzer dieses Apfels sind? AUSGEFRAGTER: Ob ich was bin?

Ausfrager D: Der glückliche Besitzer dieses Apfels?

Ausgefragter: Was für ein Besitzer?

[Neues Hörspiel, p. 29]

Handke's Hörspiel is then a demonstration of perhaps the basic function of language: the phatic function which establishes the channel and the contact necessary for any transfer of information. ${ }^{10}$ Neither the extra-linguistic situation of the play nor the twist that the interview about the interrogation is merely an extension of that interrogation, nor the clever way the situation is resolved through silence (see page 59) should be allowed to obscure this fundamental focus on language. Much of our verbal behavior concerns this aspect of language and not a few important problems are compounded because insufficient attention is paid to the satisfactory establishment of a clear channel before the channel is choked with words. By its structuralist analysis of the mechanics of interrogation Handke's Hörspiel participates in the "sprachliche Verdoppelung der Welt"11 without becoming a metaphor for an extralinguistic situation.

Although he constructs extra-linguistic situations in other Hörspiele (Starallüren, Das Fussballspiel), Ludwig Harig concentrates on language as documentation of human behavior in his Ein Blumenstück (1968). The entire work consists of a montage of children's verses, folk rhymes and sayings, and excerpts from the diary of Auschwitz commander Rudolf Höss. There is of course a prejudicial connotation of horror around the latter and an equally prejudicial connotation of wholesomeness surrounding the former. The relationship between these preconceptions and the actual content of the verbal material is the subject of the Hörspiel. In one sense Harig does the exact opposite of Handke in Weissagung, for instead of revealing the emptiness of figures of speech he reveals the "latente Gewalttätigkeit" (phrase by Jürgen Becker) packed into the most innocent of children's rhymes and folk songs. In juxtaposition to Höss's notes, a snatch of folk lore ("birkenblättertee ist ein altes volksheilmittel zur blutreinigung") becomes a sinister link to misused theories of racial supremacy; every nursery rhyme reference to violence ("der henker wird sie spalten ... steck das messer in das heu ... reiss es aus ... tritts tot ...") a memory of national violence; and every mention of Poland ("was wollt ihr denn in polen / schöner blauer jung") or roses or yellow stars ("die rosen sind gross / die bremmen sind gelbe sterne") a frightening 
connection with Germany's most painful period. Certainly it is not Harig's intent to connect the horror of the Third Reich causally with these reservoirs of verbal material. Yet, as Jürgen Becker has said in his afterword to this piece, "Kindersprache ist nicht totes Objekt; sie kann zum Instrument der Herrschenden werden, und sie verliert darüber ihre Neutralität" (Neues Hörspiel, p. 445). Just as the semantic content of the "neutral" verses and rhymes loses most of its interest when taken out of this context of juxtaposition, the sentimental notes Höss has written about his wife's flower garden have little interest value when divorced from our awareness that this sentimentality belongs to the commander of Auschwitz. The verbal material is interesting as documentary material and remains interesting only as long as we retain our awareness of this character.

The verbal behavior of America is the context for another experimental Hörspiel, Ferdinand Kriwet's Voice of America (1970). Like Harig's Blumenstück, Voice is a montage of extant (mostly verbal) material, but whereas Harig's effect is achieved through internal juxtaposition of two general sources of material, Kriwet's initial effect comes through the contrast suggested by the title with the official information programming of the United States. Instead of openly pro-American propaganda, Kriwet's Voice gives a cross section of the material actually heard in America's broadcast media. The material was gathered in a marathon session in a New York hotel room, where with one assistant, several TV sets and radios, and a battery of tape recorders, Kriwet taped the daily programs of the major networks. This material was then divided into categories such as news, station identification, commercials, prayers, sports and special events, and organized by cutting, splicing, and stereophonic distribution into the finished composition (which is considered open-ended by the author, in the sense that later versions can add new material). The result is a verbal image of a people talking to themselves.

The actual content of what is said in the various categories is often less important in this montage than the way in which it is said. The semantic content provides, of course, the sharpest contrast with the familiar (to Europeans) "Voice of America." The snatches of news broadcasts seem to have nothing to report but multiple murders domestically and the violence of war abroad; the religious appeals seem wholly unrelated to the problems revealed in these news broadcasts; and a pan-commercialism seems to taint nearly everything broadcast, from products to activities to 
the broadcasters themselves (e.g., the parallels between station call signs and other product advertising). But more central to Kriwet's expression is the iconic nature of this information, that is, the way the various types of message are delivered. The external contrast between the semantic information conveyed in the verbal images of America's voice and that conveyed in the propaganda image is accompanied by an internal contrast after all: the contrast between the media-style of delivery and the spontaneous delivery of the man interviewed on the street. This contrast emerges most clearly from the news announcements of Vietnam war activity, which after years of repetition have become stereotyped and predictable in their content and are delivered in a cool, routine, highly impersonal manner. On the other hand, the appeals of anti-war demonstrators reading the names of American casualties and reminding people that for each American name thirty Vietnamese also died, are personal, passionate, and obviously involved. On the domestic side, the news broadcasters reporting multiple murders and accidents routinely as if they happened every day (which of course they do) fade into insignificance in comparison with the voice of a woman interviewed on the street as she complains of welfare inadequacies: "Die, brother, die-that's all they want you to do." It would be wrong to see just an indictment of American broadcasting in these contrasts or in the fact that more effort seems to be spent in devising catchy jingles for the station commercials than in creating interest in domestic and national problems, for these same broadcasters have transmitted the spontaneous and impassioned voices of the truly concerned. Rather it is Kriwet's lament that our perception of the world has withered under the repeated assaults of mass communication, leaving mere recognition as our only response. ${ }^{12}$ In circular fashion this withered condition both results from the monotonous sameness in the news and events selected for broadcast, and is anticipated and then compounded by the smooth, even style of broadcasting that expects and requires nothing more than recognition of a duty performed.

Voice of America is more than merely a passive lament, however. Kriwet accepts his own challenge by restoring perception to the verbal material of American broadcasting. To begin with, he gives his montage the contours of broadcasting's daily programming: the Hörspiel opens with religious meditation, handles the business of a broadcast day (news, sports, commercials, music, etc.) and closes with a quiet good night wish. Within this parallel struc- 
ture Kriwet rekindles perception of the same verbal material by the rearrangement of individual elements. The juxtaposition of airline commercials with news broadcasts of American bombing raids in Vietnam ensures entirely fresh attention to the appeals "Fly the American Way" and "Fly the Friendly Skies of United." Such attention would be the envy of most advertising designers, even if the connotations aroused would not. Similarly, a quiet appeal to take a moment for religious meditation becomes in mid-sentence an appeal for a quiet moment with Winston cigarettes, emphasizing both the subtlety of commercial exploitation and the infiltration of these techniques into the most unlikely messages. Obviously Kriwet himself uses advertising techniques. His playfulness with the content and form of commercials would be a parody on advertising were it not for the substantial ties joining modern poetry and advertising. Both use aesthetic information to leaven the dead mass of a message and to keep perceptive faculties alive for semantic content. ${ }^{13}$ The parallels in these techniques add to the over-all parallel between the Hörspiel and its model, deepen its iconic participation in the thing represented, and maintain the focus on the problem common to all communication of stimulating perception.

We have seen language used as aesthetic information and to provide models of various kinds of verbal behavior; in Franz Mon's das gras wies wächst (1969) we find language used almost exclusively as pure verbal material. Whereas the choice of lexical material in Pörtner's Alea was determined initially by a semantic requirement, that of Handke's Hörspiel shaped by the extra-linguistic situation of an interrogation, and Harig and Kriwet's respective lexica by the documents used to illuminate verbal behavior, the model for Mon's lexicon in das gras is basically the dictionary of the German language. That is, a significant number of the words used appear in alphabetical strings without any syntactic or grammatical deformation of their dictionary forms. The first event of the Hörspiel is such a string (P1 stands for the farthest position left on the stereophonic axis, $W$ for a feminine voice, $I$ for the number of the event):

P1

I W: allmählich anschwellend

abändern abarbeiten abarten

abbalgen abbauen abbeissen

abbestellen abberufen abbezahlen

abbiegen abbilden abbitten

abblasen abblättern abblenden

abblitzen abblühen abbrechen 


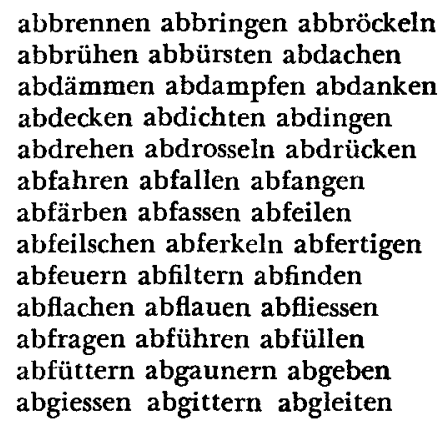

The last such string (number 79 of a total of 82 events) involves lexically the last alphabetical element:

P4

79 M2: sehr schnell

zubauen zubereiten zubilligen zubinden zublinzeln zudecken zudrängen zudrehen zudrücken zueignen zuerkennen zufallen zufliessen zuflüstern zufügen zuführen zugeben zugehen zugestehen zugreifen zuhören zujubeln zukehren zukleben zukommen zulächeln zulangen zulassen [Neues Hörspiel, p. 239]

A clearer demonstration of the concretization of verbal material, of the reduction of language to its lexical components, and of the desire to treat them as variable, fully interchangeable elements independent of grammatical, syntactic, and semantic domination would be difficult to find in the modern experimental Hörspiel. These asyntactic strings bracket the remaining material of the work, serving as notice and reminder that what lies between them is to be taken at face value as the material of language. Within this context of concrete materiality other possibilities for word combination, many of them involving normal syntax and grammar, are explored: questions are asked and answers given, short dialogues are built up and then dismantled, there are monologues with logical and semantically meaningful content and monologues built out of fragments of figures of speech with no obvious logical or semantic connections. Nor is the word the irreducible minimum element set in play. Although phonemes are not used in isolation (until the final word, when the phoneme $/ n /$ is drawn out for several seconds), the phonetic texture of some words is brought out through the repetitive devices of verbal euphony, which are used to establish acoustical and not semantic connections. In addition there are 
pre-speech or quasi-speech forms, such as whispers, breathing, and crying. In his introduction to the work Mon confirms that above all his subject is language as verbal material:

der hörer des folgenden hörspiels erfährt keine geschichte. es gibt zwar dialoge, aber keine zusammenhängende handlung. es handeln die sprachelemente. subjekte sind die wörter, die wörteragglomerationen, die gestanzten redensarten, fragepartikel, überhaupt fragen aller art, wie sie quick und twen in populären tests, in interviews, in briefkastenecken bereithalten. wörterreihen treten in spannung zu redensarten. redensarten hinterbauen dialoge. dialoge werfen fragen auf, die von wörterreihen beantwortet werden. es ist gut, sich die verschiedenen strukturtypen klarzumachen, in denen sprachliches manifest wird. ...

[Neues Hörspiel, p. 197]

But having demonstrated quickly and economically in the opening events of the work his concentration on the material level of language, Mon feels free to draw on the connotative and referential aspects of this material, although more for the expanded gameactivity such semantic overtones permit than to expose metaphoric or symbolic levels in the language. On the one hand, this interplay consists in varying synthetic verbal forms, in switching from pedantic description, to acoustical puns ("obs schon wächst?""obst ist so gesund"), to one-sided interviews, etc. On the other hand there are playful elements in the difference in imagery between the various kinds of words grouped in a-syntactic strings, i.e., between the weak associations produced by a string of lexically related verbs and the strong stimulation to verbal and object imagery produced by a string of crossword puzzle clues. This playfulness is accentuated through strong rhythmical differentiation, especially the rhythmical distribution of events and parts within events over the left-right stereophonic axis. Mon uses stereophonic differentiation and overlap to juxtapose and align elements the way the language traditionally uses syntax. In a limited sense of structuring combinations of words, sentences, and even dialogues, stereo is, as he has himself proclaimed, the new syntax of the Hörspiel. ${ }^{14}$

What I have called playfulness ought not to be thought of as sheer whimsy, although there is room for that in the experimental Hörspiel, too. Mon is so serious about demonstrating the potential for the poetic shaping of language as pure material that whimsy is not allowed the freedom in das gras which it enjoys in some other pieces. Ironically, the effort expended to keep language from falling into semantic modes, from regressing into language as medium 
for meaning, almost produces the effect it is intended to prevent. To demonstrate how easily the consciousness of materiality can be lost, Mon periodically inserts elements with very strong semantic connotations. For instance, along with strings of verbs, strings of numbers, and strings of crossword puzzle clues, he throws in strings of names. Initially such a string is pure verbal material, signifying nothing but itself-"eibel, ludwig eibel, olga eiben, erich eibensteiner, franz eiberger, hanna eibes, gustav eibich ..." (Neues Hörspiel, p. 199)-but the next entry (adolf eich) triggers connotations that begin to make us less willing to accept the rest of this list as simply verbal concreta. Since at first the name "adolf eich" prompts mainly verbal connotations, the material nature of the list is only weakened, but not wholly jeopardized. Several events later, however, in another string of names all beginning "eich-" the name Eichmann does occur, destroying through its associations the semantic neutrality of the other names. Thereafter whenever a previously harmless name like Eichmaul is used, it carries with it sufficient connotation as a result of its association with Eichmann to give its new context a foreboding stamp. In fact the frequency with which Mon uses this name or one enough like it to convey its special connotation gives the entire Hörspiel a rather dark color. Nevertheless we should be slow to ascribe to this seriousness extralinguistic thematic values. I would differ on this point with Heinrich Vormweg, ${ }^{15}$ who feels, if I understand his point correctly, that thematic connections are raised between the connotations surrounding Eichmann and other recognizable extra-linguistic situations, e.g., the references to the death of the boxer Kid Paret, the moral issues of heart transplants, military training, etc. I agree with Vormweg that there is a connection between these semantically apperceivable events and the figure of speech behind the title, but it seems to me more consistent with the manifest concern of the work for the non-semantic potential of language to view the connection as a warning to listeners not to listen for "das gras wies wächst," i.e., not to listen for nonexistent semantic themes. Like Pörtner and Handke, Mon plays with the natural tendency of our cognitive faculties to organize what we perceive, to give it meaning. ${ }^{16}$ In its resistance to meaning, the language of the experimental Hörspiel is the utter antithesis of the language of the traditional Hörspiel. Instead of medium for poetic function, language is form and content made one in the concretization of the medium for expression. To try and look too far beyond the concrete level 
of language is perhaps to miss the point. "Die konkrete Dichtung liefert keine Ergebnisse. Sie liefert den Prozess des Findens." 17

Like Paul Pörtner's Alea, Franz Mon's das gras is an extreme case of verbal innovation in the experimental Hörspiel, and both share, for many people, the burden of restricted comprehensibility. The team of Ernst Jandl and Friederike Mayröcker manages to combine true inventiveness with an extraordinary gift for transparency. The results are master examples of balance between on the one hand new uses of verbal and nonverbal material and on the other techniques familiar enough to ensure accessibility to listeners with only a classical orientation. Their joint efforts, Fünf Mann Menschen and Der Gigant, seem in fact to consolidate so well the progress made in the experimental Hörspiel during the decade of the sixties that it is tempting to speak of a reinvestment of the fruits of experimentation, if one could do so without understating the value of their own inventiveness.

Certainly there is an extra-linguistic situation in Fünf Mann Menschen. Its circular action has a definite beginning, ending, and return to the beginning. Unlike the settings of the Handke pieces, Hörspiel and Hörspiel Nr. 2, this situation is not a decoy, but remains central to the expression of the work. The language material is then to a significant extent a medium for this action, exactly as in the traditional Hörspiel. Yet, as we have already seen in our earlier discussion of this work, the fairly traditional action is accompanied by extensive experimentation in the use of dimensionality, sound effects, music, and silence. This is no less true in the use of language. One of the most strikingly inventive aspects is the playfulness with which language is used. The game principle was also involved in Mon's gras, but here the same techniques (divorce from a strictly mediate function, focus on the verbal material for its own sake) have a lightness absent in das gras. In part, this is due to the different sources for the respective lexica, as Jandl and Mayröcker look to the lighter worlds of pop culture, pubs, and school for much of their material, rather than to the dictionary. The word play in the film scene between "K.O.," "o.k.," and "koks" gains some of its buoyancy from its setting in this pop-film context. Its playfulness is more apparent too because of its extraordinary economy. The language material of the entire scene centers around just two phonemes. Where too many elements are suspended in play, the playful aspect can be obscured despite the spatial manipulation permitted by stereo. And this buoyancy emerges despite the 
serious semantic overtones of the work. The pattern of violence into which a child enters while still in the bosom of his family, the intensification of violence in the school, its romanticization in the youth culture, its legitimatization in the military, and then the somber experience that such "legitimacy" withers before the charge of existential guilt gives a coherent semantic message in place of the inconclusive semantic hints of Mon's gras. Yet while Mon intentionally destroys the materiality of his language with words of high emotional connotation, Jandl and Mayröcker preserve the ability to slip in and out of this semantic context, maintaining the balance characteristic of their work. The extra-linguistic events, situation, and figures have almost the same freedom they possess in the classic Hörspiel, with one major exception. In the authors' words:

Keine Furcht nun vor diesen; sie kommen ins Spiel, sie sind da, sie agieren, leben, und vor allem: sie schaffen Verwunderung, Überraschung, für den Autor wie für den Hörer, und dürfen nur eines nicht tun: sich etablieren.18

Because they do not establish themselves, because they are continuously dissolved again into the reality of the language as concrete material, figures and situations pose no threat to the independence of that verbal material. Almost every scene provides some instance of this process, as for example the scene in the hospital in which the figures of nurse and patient, once presented, dissolve into verbal play as semantic logic is tempered by a logic generated by the verbal material alone.

$\begin{array}{lll}\text { M1-M5 (im Chor) } & : \text { Guten Morgen, Schwester. } \\ \text { Liegen wir krank? } & \text { Vielen Dank. } \\ \text { ScHWESTER } & : \text { Nennen Sie bitte eine Zahl. } \\ \text { M1 } & : \text { Siebenunddreissig-fünf. } \\ \text { M2 } & : \text { Achtunddreissig-neun. } \\ \text { M3 } & : \text { Siebenunddreissig-acht. } \\ \text { M4 } & : \text { Sechsunddreissig-drei. } \\ \text { M5 } & : \text { Achtunddreissig-sieben. } \\ \text { ScHWESTER } & : \text { Fieber. Fieber. Fieber. Fieberfrei. } \\ & \text { Und: Fieber. } \\ \text { M2 } & : \text { Vier zu eins. } \\ \text { M5 } & : \text { Unentschieden. }\end{array}$

[Neues Hörspiel, p. 124]

Another clear example occurs in the next scene, where a judge finds all five men guilty "wegen der Schandtaten, die ihr begangen 
habt, die ihr begangen hattet, und begangen haben könntet, die ihr begangen haben werdet, begangen haben werden könntet, begangen haben werden können hättet, ZUM-(Geräusch: Gewehrsalve aus einiger Entfernung, ohne Nachhall)." In this case the momentary dissolution of the semantic situation into verbal play actually enlarges the meaning of the semantic level while toning down the illusion of a naturalistic trial. The authors' own dictum " 'hörspiel' ist ein doppelter Imperativ"19 is admirably realized in Fünf Mann Menschen, where through verbal as well as nonverbal elements perception is actualized without a refusal to mean, and part of the meaning lies in unabashed play.

To this point the present chapter has argued against the production necessity of verbal elements in the traditional Hörspiel and tried to outline some of the functions of these elements in the experimental Hörspiel. Not yet specifically dealt with is the question of whether these new uses of language in turn involve production necessity.

The answer I would venture is in many cases, no. This may be somewhat perplexing, for the marked differences in the use of nonverbal elements between the old and new Hörspiel did in fact determine in most cases the presence or absence of production necessity. In that nonverbal realm the traditional Hörspiel had used these extra-linguistic elements of music, sound effects, silence, and dimensionality predominantly as semantic signs and had found appropriate verbal codes for them. The experimental Hörspiel merely retains them in their own extra-linguistic sphere. In the verbal realm, however, even when the experimental Hörspiel loosens the verbal material from its semantic values, it remains verbal and largely codeable.

That the innovative uses of language described above do not a priori involve production necessity can be seen from the similar use of language in other forms of experimental literature, forms for which acoustical realization would be the exception rather than the rule. The prose of Arno Schmidt and Franz Mon, the visual poetry of Eugen Gomringer, Konrad Bayer, Ernst Jandl, and Helmut Heissenbüttel (to mention but a few names) involve a high degree of the very sort of tension between semantic and material aspects of language that $I$ have tried to describe as characteristic of the experimental Hörspiel.

The reader may accept this point and yet protest with good 
reason that the more appropriate comparison lies between the experimental Hörspiel and experimental acoustical poetry, since in both forms the tension operates between phonetic organization and semantic value (rather than between the spatial organization of the verbal material on the page and its semantic value). Indeed, many experimental Hörspiele of the sixties can be viewed as extended forms of concrete acoustical poetry. Typically this acoustical poetry has in fact a full measure of acoustical necessity; that is, it must be articulated (either by a performer or by the reader himself) before the experience of the text is complete. These poems explore tensions within the word, between its phonemes and the semantic value of the complete word. They assign individual phonemes roles in the communication of the aesthetic message which the grapheme for that sound cannot fill. Sometimes in fact the letters will interefere with the information conveyed by the sound, so that the tension is one between grapheme and phoneme, rather than between word meaning and sound. This tension is the key to Jandl's "oberflächenübersetzung," 20 which juxtaposes the Wordsworth verse beginning

$$
\begin{aligned}
& \text { my heart leaps up when } \mathrm{i} \text { behold } \\
& \text { a rainbow in the sky... }
\end{aligned}
$$

with an almost phonetic translation, i.e., phonetic to the extent allowed by the use of German words:

$$
\begin{aligned}
& \text { mai hart lieb zapfen eibe hold } \\
& \text { er renn bohr in sees kai .... }
\end{aligned}
$$

The phonemic level pulls strongly towards association with the English original while the lexical level tries to stay within a German context. For this tension to work it is clear that the poem must be both seen and articulated. This articulation however can clearly be accomplished by the reader's own voice. The instrument that a particular reader brings to such a performance may not be as good as the voice of a professional, but this is true of any reading. The human voice is the only instrument required. In these cases where the language material of the experimental Hörspiel has only acoustical necessity in this sense, we would not want to say it also has production necessity. For this reason works like Harig's Ein Blumenstück, Becker's Häuser, Puchert's Zybilek, and Handke's Weissagung can be read without being unfair to the acoustical 
necessity present. When the individual reader's voice becomes insufficient to render the performance required, however, acoustical necessity is superseded by what we have called production necessity. This occurs in general when the work, whether Hörspiel or acoustical poem, calls for mechanical or electronic distortion of the verbal material, simultaneous articulation of verbal events, or the use of verbal ready-mades and documents. At this point distinctions between acoustical poetry and experimental Hörspiele are very difficult to draw and may in fact be untenable. The printed text (if there is one) for the concrete poem which involves this degree of production necessity has the same limitations as the text of an experimental Hörspiel with production necessity.

Probably the clearest example in the Hörspiel of the way distortion of verbal material can make a reading unsatisfactory is Pörtner's Alea, where this material is transformed into pure sound. The extent to which the reader's own voice is incapable of producing this sort of deformation of natural speech is also the measure of this work's production necessity. In Bense and Harig's Terry Jo the initial part of the monologue is synthesized by a Vocoder and is also not replaceable by the reader's own voice. Provided the general effect of a Vocoder synthesization is known, however, the distortion is transparent enough to permit a reading of the text with no appreciable loss of effect (although in this case a silent reading would avoid problems of contamination with natural speech better than an attempt at articulation). Thus there can be no categorical measure of production necessity merely because mechanical or electronic distortion is present. The function of this distortion, its amount, and the degree to which such distortion represents a typical, familiar deformation of natural language (e.g., echo-effect) are all important factors in determining the actual extent to which distortion of the verbal elements establishes production necessity.

We must use the same caution in attributing production necessity because of simultaneous or spatially distinct articulation. Conceivably, spatial distinctiveness could be used solely to imitate a dialogue or to achieve other mimetic effects and would consequently afford no challenge to the reader's imagination. Where verbal elements are layered, however, or where dimensional play is an aesthetic or structural device, or where the filtering of some information through other elements is important as a device to impede communication, then a stereophonic realization is clearly necessary. Kriwet's Voice of America, Franz Mon's das gras, and the Jandl / 


\section{The Emergence of an Acoustical Art Form}

Mayröcker Fünf Mann Menschen are all examples of Hörspiele for which a production is necessitated in large part for these reasons.

The use of language as documentation can also bring a measure of production necessity, as is evident from the works of Ferdinand Kriwet. There the original mode of delivery of the verbal elements, their identity with certain rhythms, melodies, or acoustical contexts, is aesthetically important and must be signified iconically in a performance. On the other hand, Ludwig Harig's Ein Blumenstück, which also involves almost exclusively verbal documentation, does not necessarily involve a recognizable mode of delivery. In fact a certain arbitrariness or at least interchangeability of voices is part of the author's organizing principle, and for this reason the distribution of rhymes, folk-tale excerpts, diary sections, etc. among the adult voices, chorus, and children's voices is not fixed in the text.

The arguments above suggest that a published text can be as adequate a medium for some experimental Hörspiele as it is for the classic Hörspiel. Yet to be discussed is the value and nature of a printed text for an experimental work which does in fact have production necessity. Are such texts adequate codings of the verbal elements involved? We realize that recent efforts to make the printed text a more satisfactory substitute for the listening experience have produced two types of text: one which is written before any concrete realization has been attempted, and which therefore leaves room for various interpretations; and the renotation which is compiled on the basis of a certain performance, and which perhaps takes into account some of the contributions of the director and technicians. The former may contain material accessible to a reader but left unrealized (because unrealizable) in a given performance. More likely, the latter, the renotation, will hint at processes successfully worked out in the realization but incomprehensible when transferred to a text. For many Hörspiele, the remark ventured by Jandl and Mayröcker is absolutely correct (but note the cautious phrasing): "Zum Hörspiel-Manuskript: man könnte versuchen zu sagen, Lesbarkeit und Hörspielcharakter seien umgekehrt proportional ..." ("Anmerkungen zum Hörspiel," p. 90). As more attention is given to the careful and imaginative printing of texts, however, the degree to which a Hörspiel with considerable production necessity can be captured on paper increases. A renotation is still best understood as a reference work to the acoustical realization, however. It will be preferred over a more general text by readers who have already experienced the acoustical realization, 
but by its very accuracy to the letter of that realization will sometimes restrict the degree to which imaginative printing might closer approximate the spirit of the performance.

Let us consider the 1969 work Rhythmus $R$ by Gerhard Rühm. This is an acoustical version of a piece conceived originally in 1958 as a visual text (published by Rainer: Berlin, 1958). The renotation of the Hörspiel has been published in the WDR Hörspielbuch 1969 (Kiepenheuer \& Witsch: Cologne, 1969). The Hörspiel proceeds from the single phoneme $/ r /$, and generates from this basic verbal element words, sentences, and larger syntactic units of speech linked either directly or by association to this one phoneme. Key words, all showing the $\langle r|$ in word-initial position, introduce sections of other material, gradually forming a string beginning with REGEN and finally joining REGEN, RAUSCHT, REIZT, RINGS DEN RAND, RUCK, RINGT, REISST, REIBT, and RAST. The phonemic logic of this string is finally shaken in the penultimate section by the addition of $P R A L L$, and a new logic asserted in the final section by the /r/-less PLATZT. The "rhythm" of the REGEN string ends with the verbal event for what happens to a raindrop when it strikes the ground.

The events within each section vary from other strings of words with initial $/ r /$ to mere cues for changes in Raumakustik, and include the substitution and deletion of $/ r /$ from words as variations on the main theme. Longer syntactic patterns traverse stylistic extremes from objective enumeration to emotionally charged imperatives and play with false etymologies (rasen/rasieren) and the semantic loading of neutral words by positioning them in emotionally rich contexts.

The manifest acoustical necessity of such phonemic play is elevated to substantial production necessity by the simultaneity of many events, the mechanical distortion of speech used to emphasize certain sound qualities, and the iconic use of the sound of rain. Rhythmus $R$ is a master example of the new poetry of perception.

But because the act of perception is such a vital part of the message in this work, a reader who has not experienced the acoustical realization is better served by the text for the visual version than by the renotation of the Horspiel. The arsenal of effects in this visual version includes events not present in the acoustical realization, but it involves its medium (printed page) in much the same way the Hörspiel involves its acoustical medium. The visual version was designed as a sort of "totales Buch" and includes, for 
example, a page printed on a photograph of a human back (for the text dealing with Rippen and Rumpf), a page printed on sandpaper $(r a u h)$, a red page (from which the word rot is conspicuously absent) and a page to be torn out (rausreissen). The normally irrelevant aspects of the medium-texture, color, and background of the page, and the mechanical process of page-turning itself-are thus made signs in the visual version, carrying aesthetic information and giving this version a distinctive verbal shape bound to its medium. The acoustical version has its own shape, for its own medium. The printed text of the acoustical version lacks either shape. As the media of the two versions differ, so also does the information they carry, but the essential fact of the relationship between medium and message is lacking in the renotation of the Hörspiel. In his essay "zu meinen auditiven texten" Rühm elaborates his acute sense of this relationship:

sprache äussert sich vor allem mittels akustischer zeichen (phoneme) und optischer zeichen (grapheme). sie bedient sich also zweier voneinander grundverschiedener medien. diese zeichen müssen nicht bloss mittel zum zweck (einer bestimmten mitteilung) sein, sondern können selbst als ausdrucksmittel gesetzt werden, zeichen haben, unabhängig von ihrer mitteilungsfunktion, eine eigene realität: man sieht sie oder hört sie. löst man sie von den begriffsinhalten los und benutzt ausschliesslich ihre materiellen eigenschaften, dann entstehen buch stabenbilder oder lautkompositionen. bleiben die wortgestalten (begriffe) gewahrt, kann der informationsgehalt des textes durch verschiedene schrifttypen und -grade, die anordnung auf dem blatt usw.-oder durch betonung, klangfarbe, schallrichtung, entfernung usw. erweitert und differentziert werden (-die bedeutung des wortes "du" kann durch verschiedene artikulation einen bedeutungswandel erfahren). demnach drängt sich eine grundsätzliche unterscheidung zwischen lese- und hörtexten auf.

[Essays, pp. 47-48]

The comparison of these versions suggests that while much of what truly engages one medium will have no adequate expression in another medium, it is possible in some instances at least to find an equivalent rendering of the semantic and aesthetic information of a work in another medium in terms of that particular medium. The renotation of such a Hörspiel is valuable to deepening the experience of a hearing and may suggest possibilities for different realizations, but it is best viewed as a reference work whose effective use is predicated on, and cannot replace, the listening experience.

Having explored now both nonverbal and verbal elements of the Horspiel, we can better see the value of our initial distinction between acoustical and production necessity. For verbal elements 
a full measure of acoustical necessity may be present in a work for which an individual reading is a wholly adequate performance. The communication of semantic and aesthetic information is fully compatible with the voice (or apperceived verbal image) as performing instrument. This we found to be true even in cases such as experimental acoustical poetry where the phonetic level of language has become not only medium but message as well. It is then manifestly the case in the classic Hörspiel, where language functioned primarily for the communication of a visually oriented semantic message and participated in that message only relatively seldom, and then only to a degree of acoustical (and not production) necessity.

But even in the experimental Hörspiel it may be the case that, so far as the verbal material is concerned, production necessity is not present. The language of such Hörspiele may be highly experimental but, like its counterpart in experimental acoustical poetry, still compatible with an articulated reading. Those experimental Hörspiele whose verbal elements do manifest production necessity involve electronic or mechanical manipulation of the human voice to achieve an acoustical effect not reproducible by the unaided voice, even if an adequate coding were devised to guide the attempt. Finally, we saw that such a coding is in fact not possible because the effects achieved involve not the medium of print but an electroacoustical medium like radio.

It remains for us to note that the question of production necessity for any given Hörspiel cannot be resolved merely in terms of either verbal or nonverbal elements. Most experimental Hörspiele feature both, and the language of a Hörspiel which may in itself be fairly traditional can be structured around nonverbal elements whose production necessity is plain in such a way that the entire work achieves such a necessity. The Handke Hörspiel and Hörspiel $N r .2$ are examples of this sort of combination. The attention paid nonverbal elements in this study may seem overgenerous and should not be taken as an indication of the balance in the genre, at least at this time. Much of the argument in Chapter III applies to verbal elements as well. Quantitatively, verbal material still typically dominates nonverbal material in the experimental $H \ddot{o r}$ spiel. The semantic dominance to which both were subsumed in the classic era is vastly reduced, however, so that qualitatively something approaching a balance is often achieved.

But even while granting this preponderance of language material 
over sound effects and music, some critics would challenge the place of the experimental Hörspiel in literature, often with the argument used against experimental literature in general, i.e., that such a use of verbal material is a devaluation of language, even a destruction of language. This is a larger question than can be argued here, as the answers range from Wolf Wondratschek's "Auch das Pfeifen auf Literatur blieb Literatur" to Vormweg's defense that experimental literature attacks not language, but the materia secunda or "vorgeformte Inhalte." 21 I find convincing the arguments, like Vormweg's, which maintain that this experimentation frees language for new and yet still essentially poetic expression. If readability is a prerequisite of literature, then perhaps the ex. perimental Hörspiel showing production necessity is not literature; it may, however, still be poetry. Comparisons with a pre-literary oral tradition are probably unwarranted, but such a tradition must remind us that other possibilities for poetic expression besides the written word exist. It may be well to recall Ezra Pound's remark that "true poetry is in much closer relation to the best of music, of painting, and of sculpture, than to any part of literature which is not true poetry," 22 and to observe with Helmut Heissenbüttel the general fluidity of genres in our century:

Konnte man bis zum ersten Jahrzehnt dieses Jahrhunderts noch einigermassen deutlich sagen, was ein Bild von einem Werk der Literatur, was ein Werk der Literatur von einem der Musik usw, unterscheidet, so traten danach Impulse in den künstlerischen Prozess ein, die eine solche Unterscheidung, wenigstens zum Teil, unmöglich machten.

[Über Literatur, p. 75]

It is ironic that the label which best describes this eclectic and yet unique art form also avoids much of the discomfort experienced with narrow definitions of literature, poetry, drama, etc. The original and simple term "Hörspiel" is more appropriate now than ever before. 


\section{NOTES}

1. Broadcast in the CBS Mercury Theater of the Air on Halloween, 1998. The resulting panic is described in J. P. Chaplin, Rumor, Fear and the Madness of Crowds (New York, 1959), pp. 89-100. A fascinating psychological analysis of the event is given in Hadly Cantril, The Invasion from Mars (Princeton, 1940). The broadcast itself is available on record (Evolution 4001).

2. Gerald L. Bruns, "Silent Orpheus: Annihilating Words and Literary Language," College English, 31 (May, 1970), 824.

3. See Iván Fónagy, "Communication in Poetry," Word, 17 (1961), 214. 433.

4. Yvor Winters, "The Audible Reading of Poetry," Hudson Review, 4 (1951),

5. Horst-Günter Funke, Günter Eich: Zwei Hörspiele. Interpretationen (Munich, 1965), p. 76. See also Fischer, p. 119 for a similar dictum.

6. Paul Pörtner, "Schallspielstudien," in Essays, p. 59.

7. Occasionally this aspect of language has been involved in the traditional Hörspiel. In Herrn Walsers Raben, for example, it is significant that the victims are in jeopardy only when they lose their self-control. Knowing this, Walser calculates his verbal behavior to terrify, enrage, or otherwise excite his relatives.

8. Peter Handke, "Bemerkung zu meinen Sprechstücken," in Publikumsbeschimpfung und andere Sprechstücke (Frankfurt, 1966), p. 95.

9. Indeed, he argues against the possibility of a literature of engagement: "Eine engagierte Literatur gibt es nicht. Der Begriff ist ein Widerspruch in sich. Es gibt engagierte Menschen, aber keine engagierten Schriftsteller." Handke, "Die Literatur ist romantisch," in Handke, Prosa Gedichte Theaterstücke Hörspiel Aufsätze (Frankfurt, 1969), p. 280.

10. See Roman Jakobson, "Linguistics and Poetics," in Style in Language, ed. Thomas Sebeok (New York, 1960), pp. $355 \mathrm{f}$.

11. Helmut Heissenbüttel, Über Literatur, (Olden, 1966), p. 200: "Der Unterschied [between traditional and modern literature] ist der von symbolischer zu reproduktiver Redeweise. Statt des sprachlichen Illusionsraums bildet sich die sprachliche Verdoppelung der Welt aus." Subsequent reference in text.

12. My paraphrase of Viktor Shklovskij's argument for "making strange" (after the translation by Victor Erlich, Russian Formalism. The Hague, 1955, p. 150) suggests the many parallels in the use of language between Russian Formalism and the modern experimental Hörspiel.

13. See Bense's afterword to his konkrete poesie international (Stuttgart, 1965), n. pag.

14. See his "Bemerkungen zur Stereophonie," in Essays, pp. 129-133.

15. Heinrich Vormweg, "Dokumente und Collagen: Voraussetzungen des Neuen Hörspiels," in Essays, pp. 153-167. See his interpretation of das gras on p. 161.

16. Bense, Theorie der Texte, p. 123: "Was als Wahrnehmung beginnt, wird sogleich in die Bedeutung gehoben. ..." See also the psychological evidence for this tendency in Krech and Crutchfield, "Perceiving the World," in Wilbur Schramm, The Process and Effects of Mass Communication (Urbana, 1965), pp. $118 \mathrm{f}$.

17. Claus Bremer, Texte und Kommentare (Steinbach, 1968), n. pag.

18. Ernst Jandl and Friederike Mayröcker, "Anmerkungen zum Hörspiel," in Essays, p. 88.

19. Subtitle to "Anmerkungen zum Hörspiel."

20. Included in Jandl's collection Sprechblasen (Neuwied, 1968), p. 51.

21. Wondratschek in Essays, p. 223; Vormweg, Die Wörter und die Welt (Neuwied, 1968), p. 12.

22. Ezra Pound, The Spirit of Romance (1952; rpt. New York, 1968), p. 222. 


\section{Conclusion and Outlook}

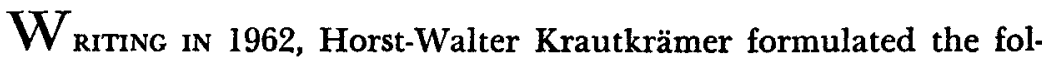
lowing principle as a starting point for criticism of the Hörspiel: "Will man beurteilen, inwieweit ein Hörspiel seine gattungsspezifische Kunstform ausfüllt, so soll man zunächst die Frage stellen: Erscheint die Wahl des Mediums zwingend?" (Krautkrämer, p. 8). An otherwise valid approach, this statement has one flaw: it fails to define what is meant by "medium." In our study we have seen that the traditional Hörspiel employs two principal media, the electroacoustical broadcast medium of radio and the creative medium of language. This observation supports Marshall McLuhan's insight that the content of any medium is itself another medium. ${ }^{1}$ Certain traditional Hörspiele, for instance those by Günter Eich, involve an acoustical medium like radio to such an extent that a visual mode of production (e.g., the stage) would seem highly inappropriate. Others, like the works of Friedrich Dürrenmatt, are at home in any of several media of production. But both live as art forms essentially in the medium of language and involve the technical aspects of the acoustical medium of radio only in the production of a given performance. Admitting, therefore, that the verbal shape of Eich's Träume limits the possible modes of its production to the acoustical is not the same as saying such a production is in fact necessary. It is at this point that the dramaturgical zeal of traditional criticism gave the theory of the Hörspiel an unwarranted skew. Helmut Jedele, in his pioneer dissertation of 1952 ("Reproduktivität und Produktivität im Rundfunk," Mainz), asked precisely the right question:

Kann der Rundfunk mit seinen Mitteln Realitäten schaffen, für deren Existenz der Transport (mit Mikrofon am Ausgangspunkt and Lautsprecher am Endpunkt des Transportweges) seins-konstituierende Bedeutung besitzt? Sollte es solche Realitäten geben, so dürften sie nicht, wie die elementar-sinnliche Wirklichkeit, schon vor dem Hindurchgehen durch das Mikrofon, ja nur dort vollwertig erlebt werden können, sie müssten im Gegenteil durch die Beschränkung auf das Akus- 
tische nicht nur keine wertminderung erleiden, sondern erst dadurch und durch die technischen Mittel des Rundfunks zu solchen Realitäten werden."

But in his search for "produktiv" radio, Jedele and the classic theorists who followed him formulated inadequate answers. In not recognizing the "elementar-sinnliche Wirklichkeit" of a poetic text, they left out of their calculations the performance given a literary text by a reader. We have seen that this is a performance in which both verbal and nonverbal elements-insofar as they serve a semantic function-can be "vollwertig erlebt." As long as the medium of radio merely broadcasts an essentially literary text (even one designed to exploit the conventions of that medium), it remains a means of reproducing and disseminating a performance of that work. The medium that is truly engaged in a productive sense is the medium of language.

The experimental Hörspiel of the $1960 \mathrm{~s}$, which we found to be very much in the mainstream of experimental literature in general, distinguishes itself from this literature by virtue of the very involvement of the electro-acoustical medium of radio absent in the classic era. It is then twice removed from its traditional cousin: once by its experimental nature, and again by the actualization of its electro-acoustical medium as a principle of its organization. Each step is essential to this differentiation, and both are mutually interdependent. Without the emancipation from semantic domination brought by the experimental principle of equal aesthetic value for all elements in a system of signs, there would have been no incentive for playing with and electronically manipulating those elements. This is the significance of the classic theorists' correct observation that for a work in which communication of semantic meaning is primary, focus on the technical aspects of a medium such as radio must be minimized. Similarly, without the development of these technical aspects, the experimentation in the Hörspiel would have been largely indistinguishable from experimental literature in other genres.

We also saw, however, that for some experimental pieces neither a traditional text nor even a careful renotation of an actual performance enables a reader to recreate for himself the experience of the work. These works have succeeded in releasing acoustical elements from what Helmut Heissenbüttel calls "ihre Rolle als 
Akzidenz der poetischen Illusion" ("Horoskop des Hörspiels," in Essays, p. 34). The sounds these pieces employ are quite simply acoustical phenomena, inseparable from their material nature as sounds. Whether used as icons or structured in a syntax proceeding from aesthetic rather than semantic principles, they are not replaceable by a graphic, visual code without undergoing significant alteration to accommodate the different medium of print.

These aspects of the experimental Hörspiel, its inability to be coded in graphic symbols and the requirement for an electromechanical instrument for its realization, generate what we have called its production necessity. At the moment the number of extant works which can claim this production necessity is relatively small. Most Hörspiele broadcast at the beginning of the seventies are more traditional than experimental, and of those which are experimental, many lack the necessary involvement of an electro-acoustical medium that makes for production necessity. Nevertheless, it is just this minority which allows us to talk about the emergence of the Hörspiel as an acoustical art form. The perspective thus brought to the genre as a whole can provide the key to long-standing problems such as the ontological question of the locus of the work. For the traditional Hörspiel this question could be approached as in the performance genres of poetry and drama. The type-token analogy borrowed from linguistics, whereby the work constitutes a "replicable, invariant structure," which is to be distinguished from its "implementation in the concrete performance," 2 has considerable appeal, once the autonomy of the text is recognized. It is of course worthwhile to analyze a given broadcast, but just as defensible (and often much more convenient) to approach a classic Hörspiel through its text. For years critics have hesitated before what seemed to them a dilemma: the practical need to work with something in hand and the conviction "dass das Kunstwerk Hörspiel eigentlich nur während der Stunde seiner Sendung lebt" (Krautkrämer, p. 11). In fact, for the traditional Hörspiel and those experimental works that do not involve production necessity, the work of critics ought to begin and end with the text, or make it perfectly clear that what is under analysis is a given performance with all the contributions and limitations of an interpretation built in. To the BBC producer Donald McWhinnie, "the business of the radio producer is to grasp the essential artistic function of sound patterns in relation to meaning ..." (Art of Radio, p. 101). I submit that this is also the business of the reader of a Hörspiel, and that in the 
case of works where there is only acoustical necessity but not production necessity, this is an eminently manageable business.

The ontological question requires a different approach in the case of a Hörspiel with production necessity. If the type-token analogy can be thought of as applying at all, the roles may have to be reversed: the acoustical realization becomes the type, text and renotation become tokens. As Klaus Schöning has said, "Für das Hörspiel schreiben, heisst auf Tonband schreiben."3 Or, as has been suggested by Vagn Steen for some forms of modern poetry, both the printed text and the acoustical realization might be considered performances of a game, and the game itself (understood as a system of possible performances) studied as the work of art. ${ }^{4}$ Either approach reflects the deep involvement of a highly technical medium, which in turn may mean that the work should be considered a co-effort of author, director, and engineer. As an alternative to this sort of teamwork, the requisite technical skill is being increasingly cultivated by the authors themselves. Franz Mon, Paul Pörtner, Kriwet, Mauricio Kagel, Richard Hey, Gerhard Rühm, and others have begun producing their own works. Pörtner: "Ich vertausche den Schreibtisch mit dem Sitz am Mischpult des Toningenieurs" ("Schallspielstudien," in Essays, p. 62). Whereas the traditional Hörspiel was conceived in the medium of print and is therefore never totally inaccessible through its text, the Hörspiel with production necessity is conceived in an electro-acoustical medium and remains an acoustical art form.

The profound changes in the traditional parameters of textrealization and author-director reviewed here contain at least one additional implication of significance for a clear view of our subject. The traditional view of the genre is predicated on the assumption that the acoustical medium involved is a priori the broadcast medium of radio. Even though live performances have practically disappeared since the development of magnetic tape, and though as a consequence tapes and records of Hörspiele could be marketed along with the texts, opportunities for listening to a Hörspiel performance apart from a radio broadcast are very restricted. Aside from the limited tape service to universities provided by Inter Nationes and occasional recordings (e.g., Cottas Hörspielbühne), the production, transmission, and reception of Hörspiele has been throughout the history of the genre a function of radio. Recently, however, several commentators have argued that the connection 
between the Hörspiel and the medium of radio is one of historical association and practical convenience, rather than of inherent necessity. The most articulate of these voices belongs to Klaus Schöning, who sees "Möglichkeiten des Hörspiels innerhalb und ausserhalb des Rundfunks" ("Vorbemerkung," in Essays, p. 7), and characterizes the genre in general as merely "eine durch den Rundfunk geförderte Darstellungsform" ("Hörspiel als verwaltete Kunst," in Essays, p. 248). It is his feeling that the genre could have developed quite independently from radio after the invention of magnetic tape, but that practical considerations (chief among which was the prohibitive cost of private production) dictated the dependency which exists in general yet today.

A counter argument directed to the past or present state of the art has, to my knowledge, not yet been advanced. What one finds instead is a mosaic of statements which claim a necessary connection between radio and the Hörspiel without really arguing why this is so. On closer examination these statements are mostly simplified attempts at definition of the genre, hangovers from the early mystique surrounding the supposed intimacy of radio reception, or merely cases of imprecise terminology. For example, Jandl and Mayröcker weaken their otherwise cogent definition of the Hörspiel by insisting on radio transmission: "Weiter wird vorausgesetzt, dass die Wiedergabe durch den Rundfunk erfolgt; sonst könnten Leute zusammenkommen, das Zimmer abdunkeln oder die Augen schliessen und mitsamen ein 'Hörspiel' spielen" ("Anmerkungen zum Hörspiel," in Essays, p. 88). The reason they offer for the involvement of radio really speaks to the issue of production necessity, and then is true only for the relatively small number of Hörspiele with this characteristic. Production necessity is quite different from broadcast necessity, which would involve not just any electroacoustical medium, but the specific medium of radio. Then Gerhard Rühm, in his essay "zu meinen auditiven texten," seems to revert to the classic concept that radio reception offers a special intimacy which can be exploited in some works, e.g., specifically in his mixakusis (= "sexuelle erregung durch geräusche"): "die anonymität und privatheit in der die radiophone rezeption erfolgt, verleitet förmlich dazu, den hörer zum lauscher, zum ecouteur werden zu lassen." 5 While listening to the radio in one's home is doubtless more private, intimate, and anonymous than attending a public reading or theatrical performance, surely it is no more so than 
playing a tape or record of the same Hörspiel over personal playback equipment.

Practically speaking, of course, there has been very little reason for distinguishing between production and broadcast necessity, radio and other electro-acoustical media. Despite the growth of sound studios independent of radio stations, e.g., in universities, commercial electronic firms, and even private homes, the factors of cost and availability of equipment probably mean a continued association of radio and Hörspiel regardless of questions of broadcast necessity. For this reason the inaccuracy of comments such as those mentioned above is probably inconsequential. Yet it would be a serious blow to the genre as a whole and particularly to the experimental Hörspiel if this sort of inaccuracy were allowed to interfere with the production of Hörspiel records and tapes. As a medium of production, radio is an important, indeed for the present at least, an indispensable base. As a medium of distribution, however, radio is simply too unwieldy to satisfy the repeated exposure the experimental Hörspiel warrants. The recent anthology Neues Hörspiel: Texte Partituren (Frankfurt, 1969), with its enclosed record, is an important step in the direction of increased accessibility, and one would hope it will be followed by greatly expanded offerings. In this respect the Swedish Broadcasting Corporation has made a significant contribution by publishing a series of recordings (Text-Sound-Compositions 1-5, Fylkingen Records, Sveriges Radios Förlag, RELP 1049, 1054, 1072, 1073, 1074) of acoustical and electro-acoustical poetry. Many of the compositions were realized in the studios of the Swedish Broadcasting Corporation's electronic music facility and several are indistinguishable from the sort of experimental work we have explored in this study. The dissatisfaction with the term "Hörspiel" evidenced by some contemporary experimenters, who prefer "Hörtexte," "auditive Texte," "Sprechstücke," "Schallspiele," etc. for their own creations may stem from an unwillingness to be linked absolutely to radio. Since there is no theoretical necessity for the involvement of a radio station in the creation and production of these works, and similarly no necessity for radio transmission, it may be misleading to continue to distinguish between experimental Hörspiele and electro-acoustical poetry. Curiously, although many of the compositions of Karlheinz Stockhausen and Mauricio Kagel have been produced in the electronic studios of radio stations, their works are not thought of as radio 
music, but as pieces with production necessity requiring one of several electro-acoustical media for realization. There are, of course, marked differences of emphasis and technique, but the similarities between poetry, music, and Hörspiel brought about by a new awareness of music as language and language as sound are too important to allow antiquated notions of radio's importance to create artificial differences. In its emergence as an acoustical art form, the Hörspiel of the sixties may have moved beyond its historical dependence on radio.

There are signs, however, that some authors and critics are unwilling to accept the diminished role of radio in the Hörspiel. Their efforts may define the thrust of the experimental Hörspiel of the 70's. As perspective is gained on the first generation of experiments, the discussion is shifting to ways of exploiting features of radio not shared by other electro-acoustical media. One of these is simultaneous contact with a large audience-ironically, the very opposite of the intimacy previously thought to be inherent in radio reception. The benefit conceived of here, and articulated for example by Michael Scharang in his essay "Übers Hörspiel-unters Hörspiel" (in Essays, pp. 181-191), is a collective reaction to the Hörspiel, as opposed to the traditional individualistic reaction to literature. An individualistic reaction is prone to be contemplative and uncritical, so this argument goes, but a collective reaction can be critical and dispassionate. Of the electro-acoustical media, only radio could generate and exploit such a large-scale collective reaction.

Another feature involves the capacity of radio for live transmission. An argument can be made for the importance of live transmission to indeterminate compositions, for instance. Since one of the principles of such works would be indeterminacy, a recording which fixes the performance and excludes this indeterminacy nullifies the piece (see Cage on indeterminacy in Silence, p. 39). Another argument stems from the fact that a live broadcast acquires an additional variable. Its shape can be changed according to audience feedback during the broadcast production. Radio alone of the strictly acoustical media would permit the audience to participate in the creation of the production. This possibility for live transmission would exploit radio's inherent capacity for two-way communication instead of mere distribution. Those interested in such a profound change in the structure of radio insist that it is now technically feasible to achieve not only a new responsiveness to the 
public but a simultaneous exchange of information-a vastly expanded, perhaps computer-assisted game activity.

The emergence of the Hörspiel as an acoustical art form is then by no means a finished process. In all likelihood works of the type illustrated in this study will survive during the second generation of experiments, along with more or less traditional works with their semantic content, plot, and characters. The radio will continue, one would hope, to provide the sort of variety that encourages growth and development of the genre as a whole. If the theoretical discussions centering around involvement of the medium of radio per se yield concrete examples, there could be new excitement in the Hörspiel of the seventies to match that produced by the experiments of the sixties. At the same time, however, one can also hope that those Hörspiele which manifest production necessity might not be limited to radio broadcasts, at least not until they also display broadcast necessity, but might find other channels for distribution which would permit a listener to select his own time and place of audition, and to give the performance the repeated attention it demands. 
108 / The Emergence of an Acoustical Art Form

\section{NOTES}

1. Marshall McLuhan, Understanding Media: The Extensions of Man, Ist McGraw-Hill paperback ed. (New York, 1965), p. 8.

2. Edward Stankiewicz, "Linguistics and the Study of Poetic Language," in Style in Language, p. 75.

3. Schöning, in an unpublished radio essay entitled "Tendenzen im Neuen Hörspiel," broadcast on October 3, 1968, in the West German Radio's (Cologne) Third Program.

4. Vagn Steen, rev. of Das literarische Werk Hans Arps, by Reinhard Döhl, $J E G P, 69(1970)$, 151-152.

5. "zu meinen auditiven texten," in Essays, p. 56. For the classic position on radio's intimacy, see Frank, pp. 84-85. 


\section{Bibliography}

\section{Part 1. Bibliographical Information for Hörspiele Cited}

A. List of abbreviated titles used in text citations and the edition for which they stand:

13 eur. Hörspiele $=$ Dreizehn europäische Hörspiele. Ed. Hansjörg Schmitthenner. Munich: Piper, 1962.

16 dt. Hörspiele = Sechzehn deutsche Hörspiele. Ed. Hansjörg Schmitthenner. Munich: Piper, 1962.

Böll, Hörspiele = Böll, Heinrich. Zum Tee bei Dr. Borsig. Hörspiele. Munich: Deutsche Taschenbuch Verlag, 1964.

Eich, Träume =Eich, Günter, Träume: Vier Spiele. Frankfurt: Suhrkamp, 1962.

Fischer, Hörspiele $=$ Hörspiele. Ed. Ernst Schnabel. Frankfurt: Fischer, 1961. Handke, Hörspiele = Handke, Peter. Wind und Meer: Vier Hörspiele. Frankfurt: Suhrkamp, 1970.

Handke, Sprechstücke $=$ Handke, Peter. Publikumsbeschimpfung und andere Sprechstücke. Frankfurt: Suhrkamp, 1966.

Neues Hörspiel =Neues Hörspiel: Texte Partituren. Ed. Klaus Schöning. Frankfurt: Suhrkamp, 1969.

Sprich = Sprich, damit ich dich sehe. Ed. Heinz Schwitzke. Munich: Paul List, 1960.

B. Alphabetical list of Hörspiele cited, according to author:

Ahlsen, Leopold. Philemon und Baukis. In Sechzehn deutsche Hörspiele. Ed. Hansjörg Schmitthenner. Munich: Piper, 1962.

Aichinger, Ilse. Besuch im Pfarrhaus. In Dreizehn europäische Hörspiele. Ed. Hansjörg Schmitthenner. Munich: Piper, 1962.

Bachmann, Ingeborg. Der gute Gott von Manhattan. In Dreizehn europäische Hörspiele. Ed. Hansjörg Schmitthenner. Munich: Piper, 1962.

-_- Die Zikaden. In Hörspiele. Ed. Ernst Schnabel. Frankfurt: Fischer, 1961.

Becker, Jürgen. Häuser. In Neues Hörspiel: Texte Partituren. Ed. Klaus Schöning. Frankfurt: Suhrkamp, 1969.

Bense, Max and Harig, Ludwig. Der Monolog der Terry Jo. In Neues Hörspiel: Texte Partituren. Ed. Klaus Schöning. Frankfurt: Suhrkamp, 1969.

Böll, Heinrich. Bilanz. In Zum Tee bei Dr. Borsig. Munich: Deutsche Taschenbuch Verlag, 1964.

Klopfzeichen. In Hörspiele. Ed. Ernst Schnabel. Frankfurt: Fischer, 1961.

Cramer, Heinz von. Die Ohrfeige. In Sechzehn deutsche Hörspiele. Ed. Hansjörg Schmitthenner. Munich: Piper, 1962.

Dürrenmatt, Friedrich. Die Panne. In Dreizehn europäische Hörspiele. Ed. Hansjörg Schmitthenner. Munich: Piper, 1962. 
Eich, Günter. Die Andere und ich. In Stimmen: Sieben Spiele. Frankfurt: Suhrkamp, 1962.

- - Fis mit Obertönen. In Hörspielbuch II. Hamburg: Europäische Verlagsanstalt, 1951.

- - Das Jahr Lazertis. In Dreizehn europäische Hörspiele. Ed. Hansjörg Schmitthenner. Munich: Piper, 1962.

- Der sechste Traum. In Neue deutsche Hefte, 3 (1956-57), 647-652.

- Träume: Vier Spiele. Frankfurt: Suhrkamp, 1962.

Frisch, Max. Herr Biedermann und die Brandstifter. In Dreizehn europäische Hörspiele. Ed. Hansjörg Schmitthenner. Munich: Piper, 1962.

Handke, Peter. Hörspiel. In Neues Hörspiel: Texte Partituren. Ed. Klaus Schöning. Frankfurt: Suhrkamp, 1969.

- Hörspiel Nr. 2. In Wind und Meer. Frankfurt: Suhrkamp, 1970.

- Kaspar. Hörspiel version unpublished. Stage version in Kaspar. Frankfurt: Suhrkamp, 1967.

-_- Weissagung. In Publikumsbeschimpfung und andere Sprechstücke. Frankfurt: Suhrkamp, 1966.

Harig, Ludwig. Ein Blumenstück. In Neues Hörspiel: Texte Partituren. Ed. Klaus Schöning. Frankfurt: Suhrkamp, 1969.

- - Das Fussballspiel. Stuttgart: edition hansjörg mayer, 1967.

- and Bense, Max. Der Monolog der Terry Jo. In Neues Hörspiel: Texte Partituren. Frankfurt: Suhrkamp, 1969.

- Starallüren. In Ein Blumenstück. Wiesbaden: Limes, 1969.

Hildesheimer, Wolfgang. Herrn Walsers Raben. In Hörspiele. Ed. Ernst Schnabel. Frankfurt: Fischer, 1961.

Hirche, Peter. Nähe des Todes. In Hörwerke der Zeit 12/13. Hamburg: Hans Bredow-Institut, 1958.

- Die seltsamste Liebesgeschichte der Welt. In Sprich, damit ich dich sehe. Ed. Heinz Schwitzke. Munich: Paul List, 1960.

Hubalek, Claus. Die Festung. In Sechzehn deutsche Hörspiele. Ed. Hansjörg Schmitthenner. Munich: Piper, 1962.

Jandl, Ernst and Mayröcker, Friederike. Fünf Mann Menschen. In Neues Hörspiel: Texte Partituren. Ed. Klaus Schöning. Frankfurt: Suhrkamp, 1969.

- Der Gigant. In WDR Hörspielbuch 1969. Cologne: Kiepenheuer \& Witsch. 1969.

Johannsen, Ernst. Brigadevermittlung. Stuttgart: Reclam, 1967.

Jens, Walter. Ahasver. In Sechzehn deutsche Hörspiele. Ed. Hansjörg Schmitthenner. Munich: Piper, 1962.

Kagel, Mauricio. (Hörspiel) Ein Aufnahmezustand. In Neues Hörspiel: Texte Partituren. Ed. Klaus Schöning. Frankfurt: Suhrkamp, 1969.

Kriwet, Ferdinand. One Two Two. In Neues Hörspiel: Texte Partituren. Ed. Klaus Schöning. Frankfurt: Suhrkamp, 1969.

- Voice of America. Unpublished.

Kühner, Heinrich. Pastorale 67. Stuttgart: Reclam, 1968.

Kyser, Hans. Ankommt eine Depesche. In Frühe Hörspiele. Ed. Heinz Schwitzke. Munich: Paul List, 1962.

Lenz, Siegfried. Das Labyrinth. In Haussuchung. Hamburg: Hoffmann and Campe, 1967.

Mayröcker, Friederike and Jandl, Ernst. Fünf Mann Menschen. In Neues Hörspiel: Texte Partituren. Ed. Klaus Schöning. Frankfurt: Suhrkamp, 1969. 1969 .

Mon, Franz. das gras wies wächst. In Neues Hörspiel: Texte Partituren. Ed. Klaus Schöning. Frankfurt: Suhrkamp, 1969. 
Pörtner, Paul. Alea. In Neues Hörspiel: Texte Partituren. Ed. Klaus Schöning. Frankfurt: Suhrkamp, 1969.

- Schallspielstudie I. Unpublished.

Puchert, Rainer. Der grosse Zybilek. In Neues Hörspiel: Texte Partituren. Ed. Klaus Schöning. Frankfurt: Suhrkamp, 1969.

Reinacher, Eduard. Der Narr mit der Hacke. In Frühe Hörspiele. Ed. Heinz Schwitzke. Munich: Paul List, 1962.

Rühm, Gerhard. Rhythmus R. In WDR Hörspielbuch 1969. Cologne: Kiepenheuer \& Witsch, 1969.

- - mixakusis / eine stereophone montage. Unpublished.

Weyrauch, Wolfgang. Die japanischen Fischer. In Sprich, damit ich dich sehe. Ed. Heinz Schwitzke. Munich: Paul List, 1960.

Wickert, Erwin. Das Buch und der Pfiff. In Hörspielbuch I. Hamburg: Europäische Verlagsanstalt, 1950.

\section{Part 2. Selected Secondary Sources}

Bachmann, Claus- Henning. "Konkretes über konkrete Dichtung: Notizen von einer Tagung in Karlsruhe," Literatur und Kritik, Heft 28 (Sept. 1968), pp. $492-494$.

Bartley, Samuel Howard. Principles of Perception. 2nd ed. New York: Harper \& Row, 1969.

Baumgärtner, Klaus. "Methodischer Stand einer linguistischen Poetik." Jahrbuch für internationale Germanistik, 1, Jg., Heft 1-2 (1969), 15-43.

Becker, Jürgen. " 'Hörspiel' von Peter Handke." Neues Hörspiel: Essays, Analysen, Gespräche. Ed. Klaus Schöning. Frankfurt: Suhrkamp, 1970. Pages 117-120.

Beckett, Samuel. Cascando and Other Short Dramatic Pieces. New York: Grove, n.d.

Benjamin, Walter. "Das Kunstwerk im Zeitalter seiner technischen Reproduzierbarkeit." Illuminationen: Ausgewählte Schriften. Frankfurt: Suhrkamp, 1961. Pages 148-184.

Benn, Gottfried. Probleme der Lyrik. Wiesbaden: Limes, 1951.

Bense, Max. Aesthetica: Einführung in die neue Aesthetik. Baden-Baden: Agis, 1965.

_-_. kleine abstrakte ästhetik. Stuttgart: hansjörg mayer, 1969.

- - Semiotik: Allgemeine Theorie der Zeichen. Baden-Baden: Agis, 1967.

--D. Theorie der Texte: Eine Einführung in neuere Auffassungen und Methoden. Cologne: Kiepenheuer \& Witsch, 1962.

Braun, Alfred. "Das erste Jahrzehnt im Berliner Vox-Haus." Rundfunk und Fernsehen, 7 (1959), 61-71.

Breicha, Otto, "Peter Handke." Rev. of Publikumsbeschimpfung und andere Sprechstücke. Literatur und Kritik. Heft 21 (Feb. 1968), pp. 57-60.

Bremer, Claus. Texte und Kommentare. Steinbach: Anabas, 1968.

Brock, Bazon. "Auf dem Wege zu einer Grammatik akustischer Umweltwahr. nehmung." Neues Hörspiel: Essays, Analysen, Gespräche. Ed. Klaus Schöning. Frankfurt: Suhrkamp, 1970. Pages 214-220.

Bruehl, Hein. "Hörspiel-Aussenaufnahmen." Neues Hörspiel: Essays, Analysen, Gespräche. Ed. Klaus Schöning. Frankfurt: Suhrkamp, 1970. Pages 168-177.

Bruns, Gerald L. "Silent Orpheus: Annihilating Words and Literary Language." College English, 31 (May 1970), 821-827.

Burger, Heinz Otto and Grimm, Reinhold. Evokation und Montage: Drei Bei. träge zum Verständnis moderner deutscher Lyrik. Göttingen: Sachse \& Pohl, 1961 . 


\section{2 / The Emergence of an Acoustical Art Form}

Cage, John. Silence. Cambridge, Mass.: The MIT Press, 1961.

Cantril, Hadley. The Invasion from Mars. Princeton: Princeton University Press, 1940.

Chaplin, J. P. Rumor, Fear and the Madness of Crowds. New York: Ballantine, 1959.

Chomsky, Noam. Language and Mind. New York: Harcourt, Brace \& World, 1968.

Chotjewitz, Peter O. "Der Regisseur und sein Autor." Neues Hörspiel: Essays, Analysen, Gespräche. Ed. Klaus Schöning. Frankfurt: Suhrkamp, 1970. Pages $134-139$.

Crutchfield, Richard and Krech, David. "Perceiving the World." The Process and Effects of Mass Communication. Ed. Wilbur Schramm. Urbana: University of Illinois Press, 1965. Pages 116-137.

Dürsteler, Heinz. "Der Expressionismus und die Sprache." Muttersprache 71 (1961). 145-148.

Duwe, Wilhelm. Die Kunst und ihr Anti von Dada bis heute. Berlin: Erich Schmidt, 1967.

Eimert, Herbert. "Elektronische Musik." Rundfunk und Fernsehen, 6 (1958), 263-270.

Enzensberger, Hans Magnus. Introduction to Vorzeichen: Fünf neue deutsche Autoren. Ed. Hans Magnus Enzensberger. Frankfurt: Suhrkamp, 1962.

Erlich, Victor. Russian Formalism: History-Doctrine. The Hague: Mouton, 1955. Esslin, Martin. The Theater of the Absurd. Rev. ed. Garden City, N.Y.: Anchor, 1969.

Fischer, Eugen Kurt. Das Hörspiel: Form und Funktion. Stuttgart: Kröner, 1964.

Fónagy, Iván. "Communication in Poetry." Word, 17 (1961), 194-218.

Dedner, Burghard. "Das Hörspiel der fünfziger Jahre und die Entwicklung des Sprechspiels seit 1965." Die deutsche Literatur der Gegenwart: Aspekte und Tendenzen. Ed. Manfred Durzak. Stuttgart: Reclam, 1971. Pages 128-147.

Frank, Armin P. Das Hörspiel: Vergleichende Beschreibung and Analyze einer neuen Kunstform durchgeführt an amerikanischen, deutschen, englischen und französischen Texten. Diss. Frankfurt, 1962. Heidelberg: Carl Winter, 1963.

Frye, Northrop. The Educated Imagination. Bloomington, Ind.: Indiana University Press, 1964.

Funke, Horst-Günter. Günter Eich, Zwei Hörspiele: Interpretationen. Munich: Oldenbourg, 1965.

-2. "Die literarische Form des deutschen Hörspiels in historischer Entwickling." Diss. Erlangen, 1962.

-_-. "Technische Mittel als eine Aussageform der Hörspielpoetik." Sprache im technischen Zeitalter, No. 11 (1964), pp. 885-893.

Geissner, Hellmut. "Spiel mit Hörer." Neues Hörspiel: Essays, Analysen, Gespräche. Ed. Klaus Schöning. Frankfurt: Suhrkamp, 1970. Pages 92-107.

-_- "Uber das Hörspiel Haiku Hiroshima von Ludwig Harig." Unpub. essay broadcast by the Westdeutscher Rundfunk, Third Program, 9 January 1969. "Gespräch: Jürgen Becker-Klaus Schöning." Neues Hörspiel: Essays, Analysen, Gespräche. Ed. Klaus Schöning. Frankfurt: Suhrkamp, 1970. Pages 192-201. "Gespräch: Mauricio Kagel-Klaus Schöning." Neues Hörspiel: Essays, Analysen, Gespräche. Ed. Klaus Schöning. Frankfurt: Suhrkamp, 1970. Pages 228-236.

Gielgud, Val. British Radio Drama: 1922-1956. London: Harrap, 1957.

Gomringer, Eugen. worte sind schatten: die konstellationen 1951-1968. Reinbek bei Hamburg: Rohwohlt, 1969.

Grunert, Joachim. "Die akustische Kulisse beim Hörspiel." Rufer und Hörer, 7 (1953), 234-238. 
Halle, Morris and Jakobson, Roman. Fundamentals of Language. The Hague: Mouton, 1956.

Handke, Peter. "Bemerkungen zu meinen Sprechstücken." Publikumsbeschimpfung und andere Sprechstücke. Frankfurt: Suhrkamp, 1966.

--. "Die Literatur ist romantisch." Prosa Gedichte Theaterstücke Hörspiel Aufsätze. Frankfurt: Suhrkamp, 1969.

Harig, Ludwig. "Brot fürs Ohr." Neues Hörspiel: Essays, Analysen, Gespräche. Ed. Klaus Schöning. Frankfurt: Suhrkamp, 1970. Pages 202-208.

Hausmann, Raoul. "Nachwirkungen des Dadaismus in der deutschen Literatur." GLL, 21 (1967-68), 21-26.

___. "Note sur le Poème Phonétique: Kandinsky et Ball." GLL, 21 (1967-68), $58-59$.

Hautumm, Hans L. "Symbolische Formen im Hörspiel." Deutschunterricht, 18. Jg., Heft 1 (1966), 54-67.

Heissenbüttel, Helmut. "Hörspielpraxis und Hörspielhypothese." Akzente, 16 (1969), 23-28.

_- "Horoskop des Hörspiels." Neues Hörspiel: Essays, Analysen, Gespräche. Ed. Klaus Schöning. Frankfurt: Suhrkamp, 1970. Pages 18-36.

- . "Klischees und Modelle." Series of 7 unpublished essays broadcast by the Westdeutscher Rundfunk, Third Program, January-March, 1969.

-_. "Musik und Hörspiel." Unpub. introduction to Mauricio Kagel's (Hörspiel) Ein Aufnahmezustand 2. Dosis broadcast by Westdeutscher Rundfunk, Third Program, 4 June 1970.

- - Uber Literatur. Olten: Walter, 1966

Herdan, G. Language as Choice and Chance. Groningen: P. Noordhoff, 1956. Hirche, Peter. "Telefoniertes Theater: Ein Selbstgespräch über die Zukuft des Hörspiels." Der Monat 19. Jg., Heft 229 (October 1967), 51-55.

Höke, Bernhard. "Hör-Spiel-Zukunft." Neues Hörspiel: Essays, Analysen, Gespräche. Ed. Klaus Schöning. Frankfurt: Suhrkamp, 1970. Pages 209-213.

Hörspiele im Westdeutschen Rundfunk: 1966-1970. Series of biannual program guides. Cologne: Westdeutscher Rundfunk.

Hofmannsthal, Hugo von. Ein Brief. Gesammelte Werke. Frankfurt: Fischer, 1951. Bd. 12.

Honig, Werner. "Möglichkeiten des Hörspiels." Sprache im technischen Zeitalter, No. 5 (1962), pp. 410-416.

Hostnig, Heinz. "Akustisches Museum Rundfunk: Polemische Gedanken über die Produktionsbedingungen." Akzente, 16 (1969), 15-22.

-_. "Erfahrungen mit der Stereophonie." Neues Hörspiel: Essays, Analysen, Gespräche. Ed. Klaus Schöning. Frankfurt: Suhrkamp, 1970. Pages 129-133.

" "Hörspiel-neues Hörspiel-Radiospiel. eine Skizze über die theoretischen Ansätze zweier Modelle." Die Literatur und ihre Medien. Ed. Ingeborg Drewitz. Düsseldorf: Eugen Diederichs, 1972. Pages 174-187.

Hund, Wulf D. "Information und Redundanz." Literatur und Kritik, Heft 28 (September 1968), pp. 474-486.

Hymes, Dell H. "Phonological Aspects of Style: Some English Sonnets." Style in Language. Ed. Thomas Sebeok. Cambridge, Mass.: MIT Press, 1960. Pages 109-131.

Ingarden, Roman. Das literarische Kunstwerk. 3rd ed. Tübingen: Max Niemeyer, 1965.

Iskra, Wolfgang. Die Darstellung des Sichtbaren in der dichterischen Prosa um 1900. Münster: Aschendorff, 1967.

Jakobson; Roman and Halle, Morris. Fundamentals of Language. The Hague: Mouton, 1956. 
Jakobson, Roman. "Linguistics and Poetics." Style in Language. Ed. Thomas Sebeok. Cambridge, Mass.: MIT Press, 1960. Pages 350-377.

Jandl, Ernst and Mayröcker, Friederike. "Anmerkungen zum Hörspiel." Neues Hörspiel: Essays, Analysen, Gespräche. Ed. Klaus Schöning. Frankfurt: Suhrkamp, 1970. Pages 88-91.

Jandl, Ernst. Laut und Luise. Olten: Walter, 1966.

- - Sprechblasen. Neuwied: Luchterhand, 1968.

Jedele, Helmut. "Reproduktivität und Produktivität im Rundfunk." Diss. Mainz, 1952.

Jens, Walter. "Der Mensch und die Dinge: Die Revolution der deutschen Prosa." Statt einer Literaturgeschichte. Pfallingen: Neske, 1957. Pages 59-85.

Jungk, Klaus. "Musik im Hörspiel." Rufer und Hörer, 7 (1952), 32-35.

Kamps, Johann M. "Beschreibung, Kritik und Chancen der Stereophonie im Hörspiel." Akzente, 16 (1969), 66-76.

-_. "Die Möglichkeiten eines zeitgenössischen Hör-Spiels lassen sich nur vermuten." Akzente, 16 (1969), 1.

Klose, Werner. "Chiffren der Wirklichkeit im Hörspiel Günter Eichs." Deutschunterricht, 18. Jg., Heft 1 (1966), 68-78.

Knilli, Friedrich. Deutsche Lautsprecher: Versuche zu einer Semiotik des Radios. Stuttgart: Metzler, 1970.

- - "Das Hörspiel in der Vorstellung der Hörer: Eine experimentelpsychologische Untersuchung." Diss. Graz, 1959.

-- Das Hörspiel: Mittel und Möglichkeiten eines totalen Schallspiels. Stuttgart: Kohlhammer, 1961.

-_- "Inventur des Neuen Hörspiels: 'Oos is Oos' von Ferdinand Kriwet." Neues Hörspiel: Essays, Analysen, Gespräche. Ed. Klaus Schöning. Frankfurt: Suhrkamp, 1970. Pages 147-152.

konkrete poesie international. Ed. Max Bense. rot 21. Stuttgart: hansjörg mayer, 1965.

Krause, Lilli. "Die Stimme im Hörspiel." Rufer und Hörer, 7 (1952), 107-110.

Krautkrämer, Horst-Walter. "Das deutsche Hörspiel 1945-1961: Grundthemen, künstlerische Struktur und soziologische Funktion." Diss. Heidelberg, 1962.

Krech, David and Crutchfield, Richard. "Perceiving the World." The Process and Effects of Mass Communication. Ed. Wilbur Schramm. Urbana: University of Illinois Press, 1965. Pages 116-137.

Kriwet, Ferdinand. "Sehtexte-Hörtexte." Neues Hörspiel: Essays, Analysen, Gespräche. Ed. Klaus Schöning. Frankfurt: Suhrkamp, 1970. Pages 37-45.

Krutch, Joseph Wood. "If you don't mind my saying so." American Scholar, 38 (Autumn 1969), 526-534.

Ladiges, Peter Michel. "Neues Hörspiel und defizitäre Verwertung von Rundfunktechnik." Neues Hörspiel: Essays, Analysen, Gespräche. Ed. Klaus Schöning. Frankfurt: Suhrkamp, 1970. Pages 108-116.

McLuhan, Marshall. Understanding Media: The Extensions of Man. New York: McGraw-Hill, 1965.

McWhinnie, Donald. The Art of Radio. London: Faber and Faber, 1959.

Maier, Rudolf Nikolaus. Paradies der Weltlosigkeit: Untersuchungen zur abstrakten Dichtung seit 1909. Stuttgart: Ernst Klett, 1964.

Matthaei, Renate. "Vorwort." Grenzverschiebung: Neue Tendenzen in der deutschen Literatur der 60er Jahre. Ed. Renate Matthaei. Cologne: Kiepenheuer \& Witsch, 1970. Pages 13-42.

Mauz, Gerhard. "Wie wird sich das Hörspiel arrangieren? Bericht über die Ulmer Hörspieltagung 1960." Die Welt, 3 June 1960. Rpt. Die Gruppe 47. Ed. Reinhard Lettau. Neuwied: Luchterhand, 1967. Pages 248-251. 
Michel, Karl Marcus. "Zurück zu den Homeriden." Afterword to Spectaculum: Texte moderner Hörspiele. Ed. Karl Marcus Michel. Frankfurt: Suhrkamp, 1963.

Miller, George A. Language and Communication. New York: McGraw-Hill, 1951. Miller, Gerald R. "Readings in Communication Theory, Suggestions, and an Occasional Caveat." Todays Speech, 19 (1971), 5-10.

Mon, Franz. "Bemerkungen zur Stereophonie." Neues Hörspiel: Essays, Analysen, Gespräche. Ed. Klaus Schöning. Frankfurt: Suhrkamp, 1970. Pages 126-128. -. "Collage und Montage in der Literatur." Das Wort. Literary supplement to $D u, 29$ (September 1969), 691-693.

Naber, Hermann. "radiospektakl-teater-radiodrama-verbosonie: Hörspiel und Hörspielversuche anderswo-ein Uberblick." Akzente, 16 (1969), 2-14.

Novak, Helga M. "Autorenkollektive?" Neues Hörspiel: Essays, Analysen, Gespräche. Ed. Klaus Schöning. Frankfurt: Suhrkamp, 1970. Pages 176-180.

Ogden, C. K. and Richards, I. A. The Meaning of Meaning: A Study of the Influence of Language upon Thought and of the Science of Symbolism. New York: Harcourt, Brace, 1959.

Peirce, Charles Sanders. The Simplest Mathematics: Collected Papers. Cambridge, Mass.: Harvard Univ. Press, 1933. Vol. 4.

Petri, Horst. "Probleme der Amalgamierung von Sprache und Musik im Hörspiel." Akzente, 16 (1969), 87-95.

Pörtner, Paul "Schallspiel-Studien." Akzente, 16 (1969), 77-87.

-_-. "Schallspielstudien." Neues Hörspiel: Essays, Analysen, Gespräche. Ed. Klaus Schöning. Frankfurt: Suhrkamp, 1970. Pages 58-70.

Poggioli, Renato. The Theory of the Avant-Garde. Trans. Gerald Fitzgerald. Cambridge, Mass.: Belknapp Press of Harvard University Press, 1968.

Reclams Hörspielführer. Ed. Heinz Schwitzke. Stuttgart: Reclam. 1969.

Reichert, Waltraud. "Informationsästhetische Untersuchungen an Dramen." Diss. Stuttgart, 1965.

Richards, I. A. and Ogden, C. K. The Meaning of Meaning: A study of the Influence of Language upon Thought and of the Science of Symbolism. New York: Harcourt, Brace, 1959.

Richards, I. A. Principles of Literary Criticism. 4th ed. New York: Harcourt, Brace and World, 1965.

Richardson, Alan. Mental Imagery. New York: Springer, 1969.

Rilke, Rainer Maria. Die Aufzeichnungen des Malte Laurids Brigge. Gesammelte Werke. Leipzig: Insel, 1927. Vol. 5.

Rohde, Hedwig. "Hörspiel als Wortmusik oder Denkspiel." Neue Rundschau, 80 (1969), 811-816.

Roszak, Theodore. "The Summa Popologica of Marshall McLuhan." McLuhan: Pro and Con. Ed. Raymond Rosenthal. New York: Funk and Wagnalls, 1968. Pages 257-269.

Rudowski, Victor Anthony. "Action as the Essence of Poetry: A Revaluation of Lessing's Argument." PMLA, 82 (1967), 333-341.

Rühm, Gerhard. "zu meinen auditiven texten.". Neues Hörspiel: Essays, Analysen, Gespräche. Ed. Klaus Schöning. Frankfurt: Suhrkamp, 1970. Pages 46-57.

Salzman, Eric. Twentieth-Century Music: An Introduction. Englewood Cliffs: Prentice-Hall, 1967.

Sanner, Rolf. "Zur Struktur des literarischen Hörspiels." Wirkendes Wort, 17 (1967), 173-185.

Scharang, Michael. "Ubers Hörspiel-unters Hörspiel." Neues Hörspiel: Essays, Analysen, Gespräche. Ed. Klaus Schöning. Frankfurt: Suhrkamp, 1970. Pages 181-191. 
Schöning, Klaus. “Anmerkungen.” Neues Hörspiel: Texte Partituren. Ed. Klaus Schöning. Frankfurt: Suhrkamp, 1969. Pages 7-16.

. "Hörspiel als verwaltete Kunst." Neues Hörspiel: Essays, Analysen, Gespräche. Ed. Klaus Schöning. Frankfurt: Suhrkamp, 1970. Pages 248-266.

-- "Tendenzen im neuen Hörspiel." Rundfunk und Fernsehen, 17 (1969), 20-30.

. "Tendenzen im Neuen Hörspiel II." Unpub. essay broadcast by the Westdeutschex Rundfunk. Third Program, on 16 April 1970.

-_-. "Vorbemerkung." Neues Hörspiel: Essays, Analysen, Gespräche. Ed. Klaus Schöning. Frankfurt: Suhrkamp, 1970. Page 7.

Schraud, Peter. "Theater als Information." Diss. Vienna, 1964.

Schwitzke, Heinz. "Bericht über eine junge Kunstform." Sprich, damit ich dich sehe. Ed. Heinz Schwitzke. Munich: Paul List, 1960. Pages 9-29.

. "Drei Thesen zum Stereo-Hörspiel." Kirche und Rundfunk, 10 July 1965, pp. 1-3.

- Das Hörspiel: Dramaturgie und Geschichte. Cologne: Kiepenheuer \& Witsch, 1963.

- - "Wertung und Wirklichkeit: Hörspielgeschichtliche Erinnerungen-ein Hörspielgeschichtlicher Rückblick." Rundfunk und Fernsehen, 7 (1959), 17-23. Shannon, Claude E. and Weaver, Warren. The Mathematical Theory of Communication. Urbana: Univ. Illinois Press, 1964.

Solt, Mary Ellen. "A World Look at Concrete Poetry." Hispanic Arts, 1 (1968), $7-65$.

Stankiewicz, Edward. "Linguistics and the Study of Poetic Language." Style in Language. Ed. Thomas Sebeok. Cambridge, Mass.: MIT Press, 1960. Pages 69-81.

Steen, Vagn. Review of Das literarische Werk Hans Arps 1903-1930 by Reinhard Döhl. JEGP, 69 (1970), 150-151.

Steiner, George. "Humane Literacy." The Critical Moment: Essays on the Nature of Literature. London Times Literary Supplement. London: Faber and Faber, 1963. Pages 21-39.

Vernon, Magdalen Dorothea. Visual Perception. London: Cambridge University Press, 1937.

-_- Eine andere Lesart: über neue Literatur. Neuwied: Luchterhand, 1972. Vormweg, Heinrich. "Dokumente und Collagen: Voraussetzungen des Neuen Hörspiels." Neues Hörspiel: Essays, Analysen, Gespräche. Ed. Klaus Schöning. Frankfurt: Suhrkamp, 1970. Pages 153-167.

-_. Die Wörter und die Welt: Über neue Literatur. Neuwied: Luchterhand, 1968.

WaIdrop, Rosmarie. Against Language? "Dissatisfaction with Language" as Theme and as Impulse Towards Experiments in Twentieth Century Poetry. The Hague: Mouton, 1971.

Weaver, Warren and Shannon, Claude E. The Mathematical Theory of Communication. Urbana: University of Illinois Press, 1964.

Weber, Werner. "Der gute Gott von Manhattan." Ingeborg Bachmann: Eine Einführung. Munich: Piper, 1963. Pages 39-44.

Weinrich, Harald. "Textlinguistik: Zur Syntax des Artikels in der deutschen Sprache." Jahrbuch für internationale Germanistik, 1. Jg., Heft 1-2 (1969), 61-74.

Wellek, René. "Retrospects and Prospects: From the View of Literary Criticism." Style in Language. Ed. Thomas Sebeok. Cambridge, Mass.: MIT Press, 1960. Pages 408-419.

Widmer, Urs. "Ein Hörspiel schreiben." Neues Hörspiel: Essays, Analysen, Gespräche. Ed. Klaus Schöning. Frankfurt: Suhrkamp, 1970. Pages 121-125. 
Wimsatt, W. K. The Verbal Icon: Studies in the Meaning of Poetry. London: Methuen, 1970.

Winters, Yvor. "The Audible Reading of Poetry." Hudson Review, 4 (1951), 433-447.

Wittgenstein, Ludwig. Philosophische Untersuchungen. Oxford: Basil Blackwell, 1953.

Wolkopf, Althea Crilley. "The Post-War German Hörspiel: A New Literary Form." Diss Boston Univ., 1966.

Wondratschek, Wolf. Untitled essay. Neues Hörspiel: Essays, Analysen, Gespräche. Ed. Klaus Schöning. Frankfurt: Suhrkamp, 1970. Pages 223-227. 